\title{
Ring-shaped morphological features and interpreted small seamounts between southern Quebec (Canada) and the New England seamounts (USA) and their possible association with the New England hotspot track
}

\author{
Ronald T. Marple ${ }^{*}$, James D. Hurd ${ }^{2}$, and Robert J. Altamura ${ }^{3}$ \\ 1. 1516 Loblolly Drive, Harker Heights, Texas 76548, USA \\ 2. Department of Natural Resources and the Environment, The University of Connecticut U-87, Room 308, 1376 Storrs Road, \\ Storrs, Connecticut 06269-4087, USA \\ 3. Consulting Geologist, 1601 Yardal Road, State College, Pennsylvania 16801-6966, USA \\ *Corresponding author <ronmarple@verizon.net>
}

Date received: 20 April 2018 Date accepted: 27 May 2018

\begin{abstract}
Enhancements of recently available high-resolution multibeam echosounder data from the western Gulf of Maine and Atlantic continental margin and light detection and ranging (LiDAR) and digital elevation model data from southeastern Quebec (Canada) and the northeastern United States have revealed numerous ring-shaped morphological features and interpreted small seamounts between the Monteregian Hills igneous province and the New England seamounts. The morphological features onshore are mainly ring-shaped depressions, several of which surround mapped igneous intrusions in the Monteregian Hills igneous province and White Mountain magma series. Most of the rings offshore are also depressions, although a few rings are curved ridges above the seafloor. The largest ring in the western Gulf of Maine is the 30-km-diameter Tillies ring that lies $20 \mathrm{~km}$ east of Cape Ann, MA. Several small ( $<3 \mathrm{~km}$ in diameter) round, flat-topped submerged hills that we interpret to be volcanic necks are also present beneath the western Gulf of Maine. The rings between Cape Cod and the continental slope are more subtle because of thicker sediments and poorer spatial resolution of the sonar data in this area. The southernmost ring-shaped features are located on the continental slope and upper continental rise and coincide with the northwestern end of the New England seamount chain. The concentration of these features between the Monteregian Hills igneous province and the New England seamounts suggests that they are igneous features that may be associated with the New England hotspot track.
\end{abstract}

\section{RÉSUMÉ}

L'amélioration de données récentes d'un échosondeur multifaisceaux de haute résolution dans l'ouest du golfe du Maine et la marge continentale de l'Atlantique ainsi que les données de détection et télémétrie par ondes lumineuses (LiDAR) et du modèle altimétrique numérique dans le sud-est du Québec (Canada) et dans le nordest des États-Unis ont révélé de nombreuses caractéristiques morphologiques en forme d’anneau et ce que nous interprétons comme de petits monts sous-marins entre la province ignée des collines montérégiennes et les monts sous-marins de la Nouvelle-Angleterre. Les caractéristiques morphologiques côtières sont principalement des dépressions en forme d’anneau, dont plusieurs qui entourent des intrusions ignées cartographiées dans la province ignée des collines montérégiennes et la série magmatique des White Mountains. La plupart des anneaux extracôtiers sont également des dépressions, bien que quelques anneaux soient des crêtes arrondies qui s'élèvent au-dessus du plancher océanique. L'anneau le plus grand dans louest du golfe du Maine est celui de Tillies. Mesurant $30 \mathrm{~km}$ de diamètre, il est situé à $20 \mathrm{~km}$ à lest de Cape Ann, dans le Massachusetts. Plusieurs petites (moins de $3 \mathrm{~km}$ de diamètre) collines submergées, rondes et à sommet plat, que nous interprétons comme des necks volcaniques, sont présentes également au-dessous de l'ouest du golfe du Maine. Les anneaux entre Cape Cod et la pente continentale sont plus subtils en raison des sédiments plus épais et d'une plus faible résolution spatiale des données du sonar dans cette région. Les caractéristiques en anneau les plus au sud se trouvent sur la pente continentale et le glacis continental supérieur et coïncident avec l'extrémité nord-ouest de la chaîne de monts sous-marins de la Nouvelle-Angleterre. La concentration de ces caractéristiques entre la province ignée des collines montérégiennes et les monts sous-marins de la Nouvelle-Angleterre permet de penser qu'il s'agit de caractéristiques ignées qui pourraient être associées au tracé du point chaud de la Nouvelle-Angleterre.

[Traduit par la redaction] 


\section{INTRODUCTION}

Marple and Altamura (2015a) and Marple et al. (2015) used light detection and ranging (LiDAR) and digital, high-resolution multibeam echosounder (MBES) data to map ring-shaped depressions and ridges in southeastern New Hampshire and the western Gulf of Maine. They concluded that these features may be related to igneous intrusions produced by the New England hotspot. This paper represents a follow-up on that work, extending the study in the western Gulf of Maine to the continental margin to the southeast and the area onshore to the northwest. Our data reveal numerous new ring-shaped features, arc-shaped scarps, and interpreted small $(<3 \mathrm{~km})$ volcanic necks and seamounts (Figs. 1-3). We integrated those observations with gravity, aeromagnetic, and seismic-reflection data to help determine the origin of those features. In addition, we have used LiDAR and digital elevation models (DEM) to determine if similar morphological features occur onshore along the trend between the Monteregian Hills igneous province (MHIP) and the White Mountain magma series
(WMMS). Based on our findings, we hypothesize that the various morphological features between the MHIP and the New England seamounts (NES) are igneous-related features that may have formed in response to the New England hotspot as the North American plate moved northwestward over the plume.

\section{NEW ENGLAND HOTSPOT TRACK (NEHT)}

The NEHT (also known as the Great Meteor or Monteregian hotspot track) has been proposed to explain the existence of the MHIP, WMMS, and NES (e.g., Crough 1981; Duncan 1984; Sleep 1990) (Figs. 1 and 2). More recent studies have extended it farther to the northwest (e.g., Heaman and Kjarsgaard 2000; Ma and Eaton 2007; Zurevinski et al. 2011). Zurevinski et al. (2011), for example, postulated that the NEHT extends from Nunavut in northern Canada to the Miocene Great Meteor Seamount. Based on Sr-Nd ages of perovskite from kimberlites of eastern Canada and the northeastern United States, combined with similarity in the

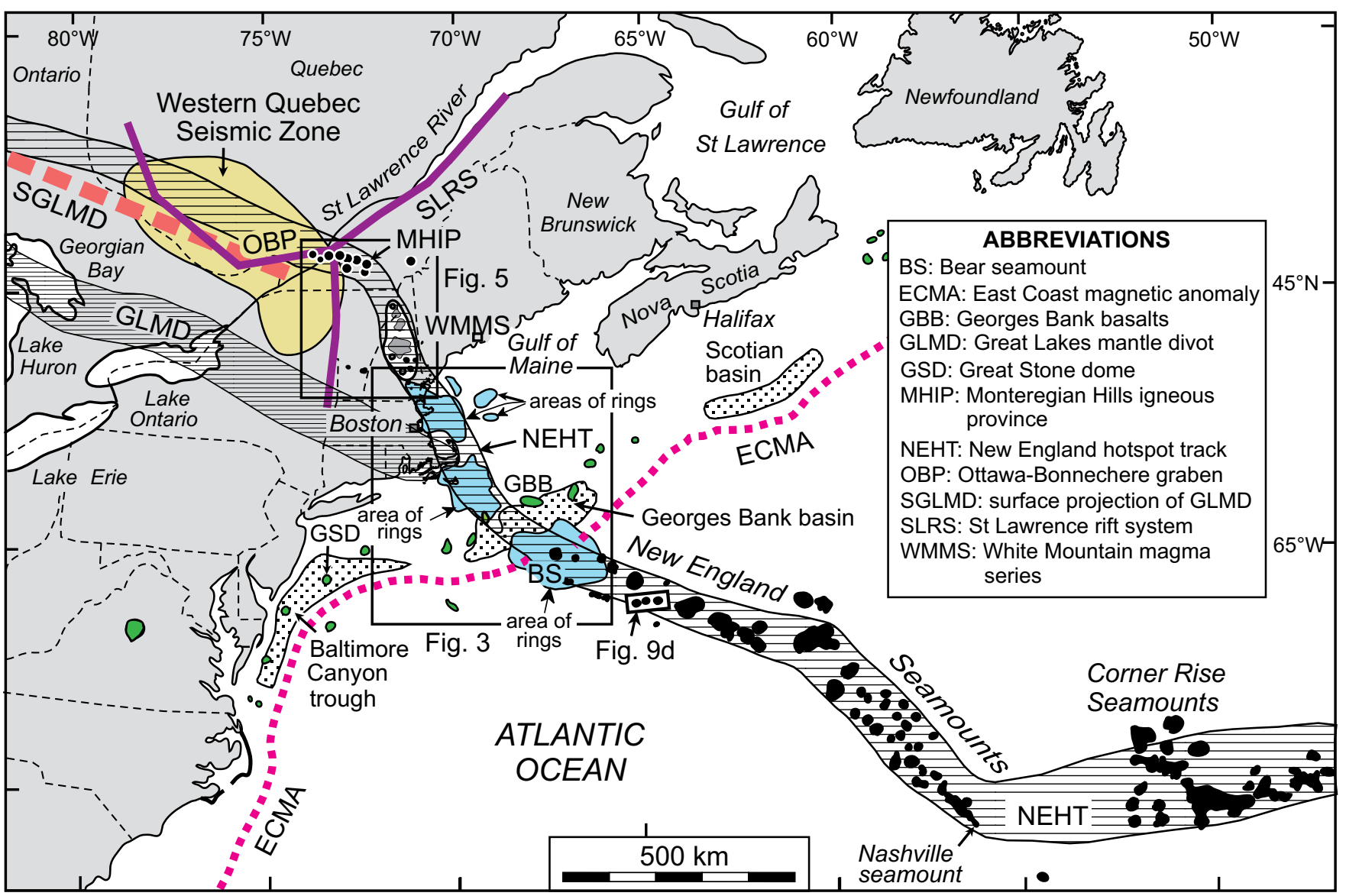

Figure 1. Map showing the proposed path of the New England hotspot track (NEHT; striped pattern). The various belts of ring-shaped morphological features are shown as blue patterns. The yellow pattern is the Western Quebec seismic zone taken from Ma and Eaton (2007). GLMD (thin horizontally striped pattern) and SGLMD (thick orange dashed line) are from Rondenay et al. (2000) and Aktas and Eaton (2006). Green patterns are igneous intrusions from plate 2C of Klitgord et al. (1988). 


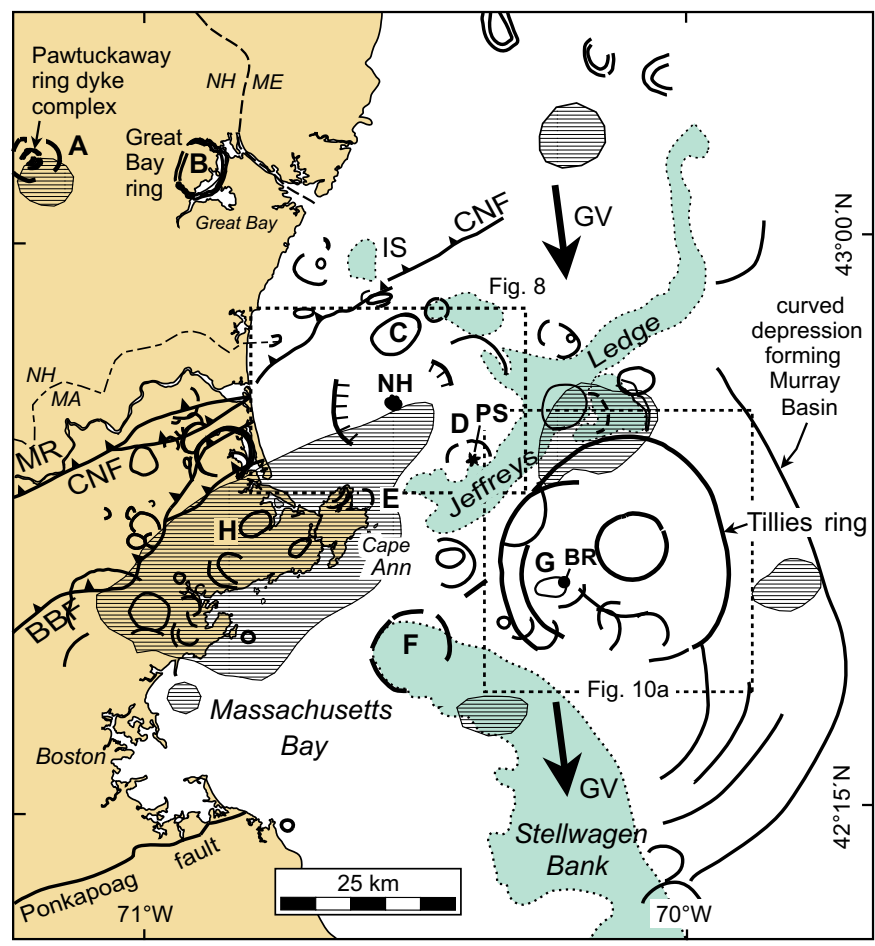

Figure 2. Summary map showing the northern belt of ring-shaped morphological features. $\mathrm{BBF}$ and $\mathrm{CNF}$ are the Bloody Bluff and Clinton-Newbury faults. Ring-shaped features denoted $\mathrm{A}-\mathrm{H}$ and interpreted volcanic necks at locations D and $\mathrm{G}$ are shown in Figures 6a, 8, 9a, 11, 13, and 22. BR, NH, and PS are the interpreted small volcanic necks named Boston roundtop, Newberry hill and Petras star. The solid arrows labeled GV are the general south-southeast direction of the Laurentide ice sheet. The horizontal-striped pattern indicates positive magnetic anomalies interpreted from Figure 31. IS (grey pattern) and MR are the Isles of Shoals and the Merrimack River.

isotopic composition of the diverse magmas along the proposed $>3000 \mathrm{~km}$ long hotspot track, they postulated that the New England hotspot produced a progressive decrease in the age of magmatism from the Triassic Rankin Inlet kimberlites to the Great Meteor Seamount.

Ma and Eaton (2007) postulated that the NEHT represents a broad zone of structural weakness that is largely responsible for the NW-SE-oriented, 160-km-wide, 500-km-long Western Quebec Seismic Zone (WQSZ) (Fig. 1). Although some of the seismicity may locally be explained by the reactivation of Precambrian normal faults and mafic dikes associated with the Ottawa-Bonnechere and St. Lawrence Precambrian rifts, they postulated that the overall distribution of earthquakes in the WQSZ is best explained by the NEHT. They hypothesized that two conceptual models could explain the association between the NEHT and seismicity in the WQSZ. According to one model, reheating, either by thermal diffusion from deep-seated magmatism or by advection of heat due to shallower crustal intrusions, could have weakened the pre-existing faults sufficiently to cause them to be reactivated. The second model was proposed by
Dineva et al. (2007) who suggested that part of the seismicity is from stress concentrations caused by the emplacement of mafic bodies into a more felsic crust along the NEHT.

Seismic tomographic studies also support the existence of the NEHT in southern Quebec and the northeastern U.S. (e.g., Rondenay et al. 2000; Aktas and Eaton 2006; Eaton and Frederikson 2007; Villemaire et al. 2012; Schmandt and Lin 2014). Aktas and Eaton (2006), for example, generated a 3-D tomographic inversion model from which they interpreted a broad, $400-\mathrm{km}$-wide, 1300-km-long, NW-SEoriented, low-velocity zone at $\sim 200 \mathrm{~km}$ depth (upper mantle) beneath the lower Great Lakes region where the Canadian Shield tectosphere was partially breached by the New England (Great Meteor) plume (Fig. 1). This low velocity zone in the lower lithosphere cuts across the structural grain of the 1.21-0.98 Ga Grenville orogen and is collinear with the NES to the southeast. Aktas and Eaton (2006) further hypothesized that this upper-mantle region is connected to the MHIP to the northeast by a low-velocity zone that dips $\sim 60^{\circ}$ to the southwest. Eaton and Frederiksen (2007) postulated that the misalignment between the anomaly at 200 $\mathrm{km}$ depth (Great Lakes mantle divot) and the MHIP and WMMS was caused by the westward displacement of the base of the track from the surface by viscous coupling of the North American cratonic keel with mantle flow. Based on teleseismic P- and S-wave traveltime tomography from the EarthScope programs's USArray network of seismometers in the northeastern USA, Schmandt and Lin (2014) also defined a low-velocity anomaly at $\sim 60-300 \mathrm{~km}$ depth beneath the northern Appalachian orogen that they attributed to the NEHT. Roden-Tice et al. (2009) presented evidence from apatite fission-track data in northern New England that further supports the presence of a long-term lithospheric thermal anomaly during the Cretaceous, which they postulated could be associated with the NEHT.

Other studies have argued against the existence of the NEHT. McHone (1996), for example, presented a number of arguments against the hotspot hypothesis, including the lack of known igneous complexes offshore between the WMMS and NES, the apparent lack of uplift along the NEHT, the presence of late Mesozoic igneous rocks in the New England region that do not follow a hotspot track, and the nonprogressive ages of igneous rocks in the MHIP and WMMS. McHone and Shake (1992) and McHone (1996) suggested that magmatism in the New England area is best explained by tectonic events and reactivation of pre-existing structures in the lithospheric plate. Other mechanisms that have been proposed to explain the MHIP and WMMS include leaky transform faults (Foland and Faul 1977), southeastward-propagating tensional events (Bedard 1985), and lithospheric extension during the Cretaceous opening of the North Atlantic Ocean that caused normal-sense reactivation of the Ottawa-Bonnechere and St. Lawrence paleorifts (Roulleau and Stevenson 2013). 


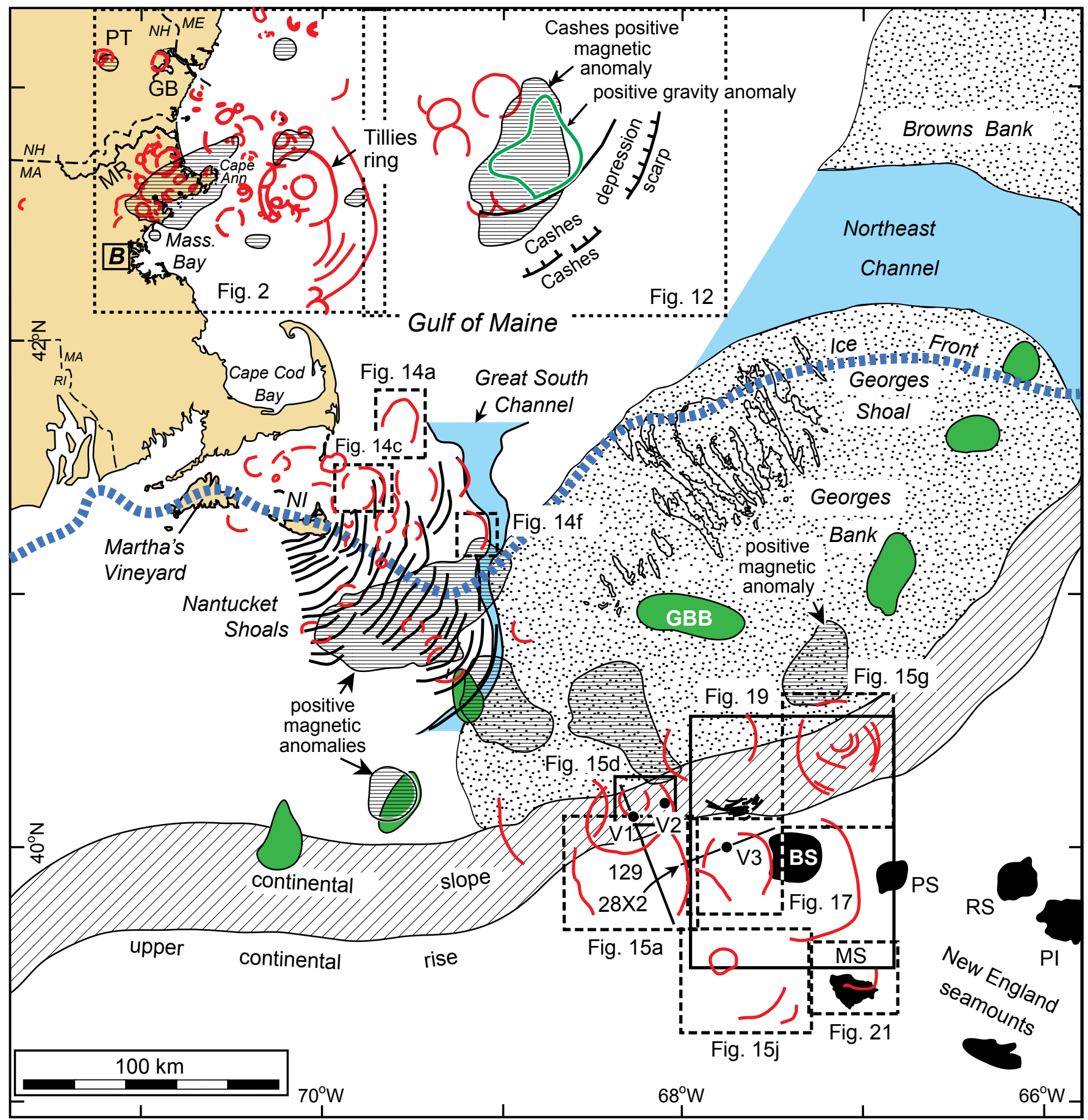

Figure 3. Map showing the locations of ring-shaped morphological features (red contours) offshore. BS, MS, PS, RS, and PI are the Bear, Mytilus, Physalia, Retriever, and Picket seamounts, respectfully. Igneous intrusions are also shown as green patterns. PT is the Pawtuckaway igneous ring dike complex. The thick green curve east of Tillies ring is a positive gravity anomaly interpreted from Figure 32. The thick dashed curve is the southern extent of the Laurentide ice sheet from Uchupi and Bolmer (2008). The horizontal striped patterns are positive magnetic anomalies interpreted from Figures 30 and 31. Dots labeled V1-V3 are interpreted seamounts or volcanic necks on the continental slope and rise. Lines labeled 129 and $28 \mathrm{X} 2$ are the locations of the seismic-reflection profiles shown in Figures 16, 18, and 20. Abbreviations B, GB, and MR are Boston, Great Bay estuary, and the Merrimack River, respectively.

\section{METHODS AND DATA USED}

Initially, we investigated the area beween the WMMS and NES using digital, high resolution MBES data, LiDAR and DEM imagery, topographic and bedrock geologic maps, gravity and aeromagnetic anomaly maps, and marine 
seismic-reflection profiles to search for possible igneousrelated features. We then investigated the area between the MHIP and WMMS using topographic and bedrock geologic maps and LiDAR and DEM images to determine if similar morphological features exist along this trend.

In northeastern Massachusetts and New Hampshire, we interpreted LiDAR imagery with $1-\mathrm{m}$ resolution that we acquired from the MassGIS Data (2016) and NH GRANIT (2016) websites. Because reflections from vegetation can be filtered out during processing to yield a "bare earth" model, LiDAR data are ideal for mapping geologic structures beneath the thick vegetation in New England. Shaded relief images were created from the DEM data using the Hillshade tool in ArcGIS and using various illumination azimuths, an elevation angle of $25^{\circ}$, and a vertical exaggeration of $10 \times$. Color relief images were then created using a color scheme based on elevations of the terrain. Low contrast images were digitally enhanced using the contrast enhancement and intensity-hue-saturation (IHS) routines of Adobe Photoshop. We were not able to generate elevation scales for LiDAR images that we digitally enhanced using the IHS routine because it significantly changed their color schemes.

To search for morphological features offshore that could be related to igneous intrusions, we used the digital, high resolution MBES data that were collected during 2002-2004 by the Science Applications International Corporation (SAIC) for the University of New Hampshire Center for Coastal and Ocean Mapping-Joint Hydrographic Center (UNH/ CCOM-JHC) and by the National Oceanic and Atmospheric Administration (NOAA) (Ward and Johnson 2016). Most of these data were collected with 2- to 5-m resolution and then combined into a single data set called the Western Gulf of Maine Bathymetry Synthesis (UNH/CCOM-JHC 2015a). Images extracted from these data typically have lower contrast and, therefore, had to be digitally enhanced using Adobe Photoshop.

The MBES data that we used to interpret morphological features along the continental slope and rise were collected between 2004 and 2008 at a lower, 100- to 200-m resolution because of the greater water depths (UNH/CCOM-JHC 2015b). Because these data are digital, we were able to construct 2-D bathymetric profiles across the various interpreted features in the seafloor. Unfortunately, striping and other artifacts occur in some areas as a result of sonar acquisition and from piecing together the various data sets. Like the MBES data from the western Gulf of Maine, these low contrast images also required digital enhancement.

For the continental shelf southeast of Nantucket Island (Fig. 3), we used the older generation analog sonar data (base map from UNH/CCOM-JHC 2015a) because no multibeam sonar data have been collected in this area. We, therefore, could not generate bathymetric profiles across any features located in that area because of the lack of depth information. These imagery were also digitally enhanced using Adobe Photoshop.

For southern Quebec, northern Vermont and New Hampshire, we used DEM data because no LiDAR data were available in these areas. The DEM data for Vermont and New Hampshire were obtained from the United States (U.S.) Geological Survey (2017) and NH GRANIT (2016) websites while the DEM data for southern Quebec were obtained from the Natural Resources Canada (2017) website. The original spatial resolution of the Vermont and New Hampshire DEM data was $\sim 8 \mathrm{~m}$ (U.S. Geological Survey 2017; NH GRANIT 2016) while the spatial resolution for the Canadian DEM data was $\sim 17 \mathrm{~m}$ (Natural Resources Canada 2017). We resampled most of these data to $3 \mathrm{~m}$ so that the different data sets could be mosaicked together for interpretation. The rest of the processing steps for the DEM data were the same as those that we used for the LiDAR data.

We rated the quality of the various ring-shaped features based on (1) how much of a complete ring they formed and (2) whether the ring was interpreted from analog sonar data versus digital MBES, LiDAR or DEM imagery. Arc-shaped features that form at least $60 \%$ of a complete circle are higher quality than other shorter partial rings. A major disadvantage of the analog data is that water depths are not available to determine if rings identified in these areas are associated with depressions or ridges. Therefore, the rings mapped between Nantucket Island and the shelf edge are of lower quality. Conversely, high-quality rings are complete rings that were identified from the high-resolution LiDAR or MBES data. Lastly, the coincidence of small seamounts or igneous intrusions with ring-shaped features greatly increased their likelihood of being related to an igneous intrusion at depth.

We further investigated the morphological features that we interpreted from the MBES, DEM, and LiDAR data using detailed topographic and bathymetric profiles that we constructed from these data. These profiles were used to quantify how much the ring-shaped depressions and ridges were depressed below or elevated above the surrounding seafloor or terrain. These features were then spatially compared with the gravity and aeromagnetic anomaly maps of Schlee and Klitgord (1988) and Daniels and Snyder (2004) to determine if they are associated with positive magnetic or gravity anomalies, which would be expected with mafic igneous intrusions. Felsic igneous rocks such as granite and rhyolite, in contrast, would not likely produce positive magnetic anomalies because they typically contain relatively low amounts of mafic minerals. The maps created by Daniels and Snyder (2004) were digitally illuminated from various directions to determine the best illumination direction to further investigate features identified on the MBES, LiDAR, or DEM images.

We also used deep seismic-reflection profiles from the National Archive of Marine Seismic Surveys (NAMSS) of the U.S. Geological Survey (Triezenberg et al. 2016) to further investigate the rings and small seamounts along the outer continental shelf, slope, and rise (Fig. 3, Table 1). These data were acquired between 1975 and 1990 by various U.S. Department of the Interior agencies and petroleum exploration companies. Unfortunately, no deep seismicreflection profiles have been acquired across the proposed NEHT where it traverses the western Gulf of Maine. 
Table 1. NAMSS seismic-reflection profiles used in this study.

\begin{tabular}{cccccc}
\hline $\begin{array}{c}\text { Seismic Profile } \\
\text { Number }\end{array}$ & $\begin{array}{c}\text { Field Activity } \\
\text { Identifier }\end{array}$ & Contributor & Platform & $\begin{array}{c}\text { Year } \\
\text { Acquired }\end{array}$ & Migrated? \\
\hline $28 X 2$ & B-10-82-AT & BOEM & Geco Alpha & 1982 & unmigrated stack \\
129 & B-03-81-AT & BOEM & Geomar II & 1983 & $\begin{array}{c}\text { migrated } \\
\text { migrated }\end{array}$ \\
\hline
\end{tabular}

Abbreviations: NAMSS = National Archive of Marine Seismic Surveys (from Triezenberg et al . 2016); BOEM = Bureau of Ocean Energy Management.

We then examined the area between the MHIP and WMMS to determine if the ring-shaped morphological features identified offshore continue onshore to the northwest. The final step in our investigation was to extend our search east and west away from this area to determine if the ringshaped features are unique to this trend. Such a concentration of these features along this trend would suggest that they are associated with the same mechanism that produced the MHIP, WMMS, and NES.

\section{GEOLOGIC SETTING OF THE STUDY AREA}

\section{Regional geology}

Three major NE-SW-trending terranes underlie the Gulf of Maine and adjacent onshore area (Fig. 4). Ganderia (Hibbard et al. 2006), including the Merrimack and Central Maine terranes of earlier workers, consists mainly of Silurian to Ordovician metasedimentary rocks and Silurian to Devonian plutonic rocks (e.g., Zen et al. 1983). Avalonia (Fig. 4) is a peri-Gondwanan microcontinent dominated by arc-related volcanic, plutonic, and volcaniclastic rocks (Hibbard et al. 2006). The northwestern part of Avalonia in the western Gulf of Maine is cut by the NE-SW-trending Gulf of Maine fault zone (GMFZ), which is characterized by a zone of southeast-dipping thrust faults associated with the Alleghanian tectonic front (Hutchinson et al. 1988). Avalonia extends onshore to the south to include Late Precambrian to Cambrian rocks of the Boston basin, which is a fault-bounded intra-arc basin filled predominantly with the Roxbury Conglomerate and Cambridge Argillite (Thompson et al. 2014).

The Meguma terrane is southeast of Avalonia (Fig. 4) and consists of a thick package of Early Cambrian to Early Ordovician metasandstone and slate (Goldenville and Halifax groups) that is locally overlain unconformably by Early Silurian to Early Devonian slate, quartzite, and volcanic rocks of the Rockville Notch Group (White and Barr 2012). These rocks were deformed and variably metamorphosed (greenschist to amphibolite facies) during the Early to Middle Devonian Neoacadian orogeny and are intruded by numerous, late syntectonic to post-tectonic, mainly Late Devonian, peraluminous granitic plutons (White and Barr 2012).

Superimposed on Avalonia and the Meguma terrane are several NE-SW-oriented, Late Triassic-Early Jurassic rift ba- sins that formed during the breakup of Pangea (e.g., Manspeizer and Cousminer 1988) (Fig. 4). These basins are filled with thousands of metres of continental terrigenous strata that consist mainly of arkosic sandstone, siltstone, shale, and conglomerate that are interbedded with layers of basalt (e.g., Zen et al. 1983).

\section{New England seamount chain}

The NW-SE-trending New England seamount chain consists of large (up to $50 \mathrm{~km}$ wide) seamounts extending more than $1300 \mathrm{~km}$ from Bear Seamount on the upper continental rise to the Corner Rise seamount complex in the foothills of the Mid Atlantic Ridge (de Boer et al. 1988) (Fig. 1). Dredged and drilled samples of the NES consist predominantly of alkali diabase and volcanic rocks (Houghton et al. 1977, 1979; Duncan 1984; Taras and Hart 1987). The seamounts increase in age northwestward from $82 \mathrm{Ma}$ for the Nashville Seamount to $103 \mathrm{Ma}$ for the Bear Seamount at the northwest end of the seamount chain (Duncan 1984) (Fig. 1).

\section{White Mountain Magma Series (WMMS)}

The WMMS (Fig. 5) consists of two groups of igneous intrusions that originated from the lower crust and mantle (Eby 1985, 1987). The older intrusions are between 220 and $155 \mathrm{Ma}$ (Triassic-Jurassic) while the younger intrusions are between 130 and $100 \mathrm{Ma}$ (Cretaceous) (Eby 1987). The older intrusions are mostly composed of syenite, quartz syenite, and granite whereas the Cretaceous intrusions consist mainly of syenite, quartz syenite, and granite, as well as gabbro and diorite (Eby 1987; Eby and McHone 1997). Ring dike complexes are common in both groups of intrusions (e.g., Figs. 6a-6c) (Eby and McHone 1997).

\section{Monteregian Hills Igneous Province (MHIP)}

Northwest of the WMMS is the ESE-WNW-oriented MHIP of southern Quebec (Fig. 5). These Cretaceous intrusions consist of a group of small $(<10 \mathrm{~km}$ wide) alkaline stocks and plugs that were intruded into the CambrianOrdovician sedimentary rocks of the St. Lawrence Platform and the folded and thrusted Lower Paleozoic sequence of the Appalachian fold belt (Eby 1987) (Fig. 5). Many of these intrusions form round, flat-topped hills (Fig. 6e). The westernmost of these intrusions, the Oka pluton (Fig. 5), consists 


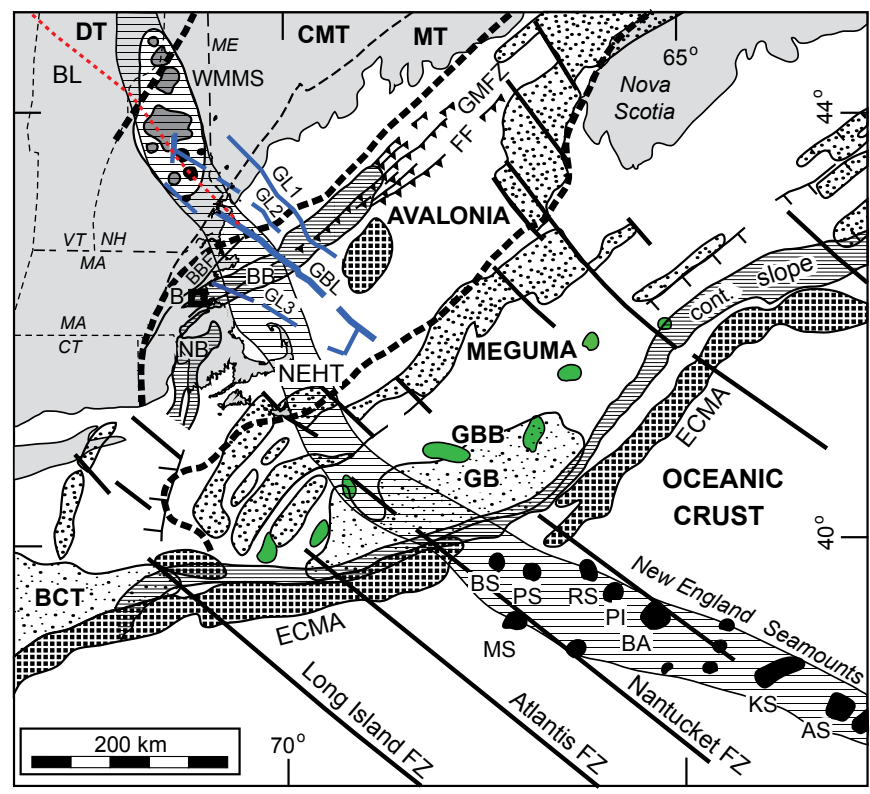

Figure 4. Map of the Gulf of Maine area (modified from McHone 1996 and Uchupi and Bolmer 2008) showing the major pre-Mesozoic terranes (between thick dashed lines), Late Triassic - Early Jurassic rift basins (stippled areas), plutons (green patterns), New England seamounts, and Mesozoic faults (solid lines with ticks on downthrown side). NEHT (striped pattern) is the New England hotspot track. $\mathrm{BB}, \mathrm{GB}$, and $\mathrm{NB}$ are the Boston, Georges Bank and Narragansett basins. BCT is the Baltimore Canyon Trough. The dashed line labeled $\mathrm{BL}$ is the Burlingon lineament of McHone and Shake (1992). ECMA, GBB, and WMMS are the East Coast magnetic anomaly, Georges Bank basalts, and White Mountain magma series (grey patterns are Jurassic intrusions and black patterns are Cretaceous intrusions). CMT, DT, and MT are the Central Maine, Dunnage, and Merrimack terranes of Hutchinson et al. (1988). The NW-SE-trending oceanic fracture zones are taken from Klitgord et al. (1988) and the gravity lineaments (GL1-GL3 and GBL) are interpreted from Figure 32. AS, BA, BS, KS, PI, PS, MS, and RS are the Atlantis, Balanus, Bear, Kelvin, Picket, Physalia, Mytilus, and Retriever seamounts. BBF is the Bloody Bluff fault, FF is the Fundy fault, and GMFZ is the Gulf of Maine fault zone (teeth on the upthrown side). B is the location of Boston.

of carbonatite and other strongly silica-undersaturated lithologies whereas the other intrusions consist mainly of nepheline-normative gabbro and pyroxenite, nephelinebearing diorite, and feldspathoid-bearing syenite and monzonite (Eby 1987). The MHIP intrusions fall into two age groups, one between 130 and $140 \mathrm{Ma}$ and the other between 118 and $122 \mathrm{Ma}$ (Eby 1984a).

Stratigraphy and surficial geology onshore and beneath the western Gulf of Maine

The sediments that cover the various terranes between

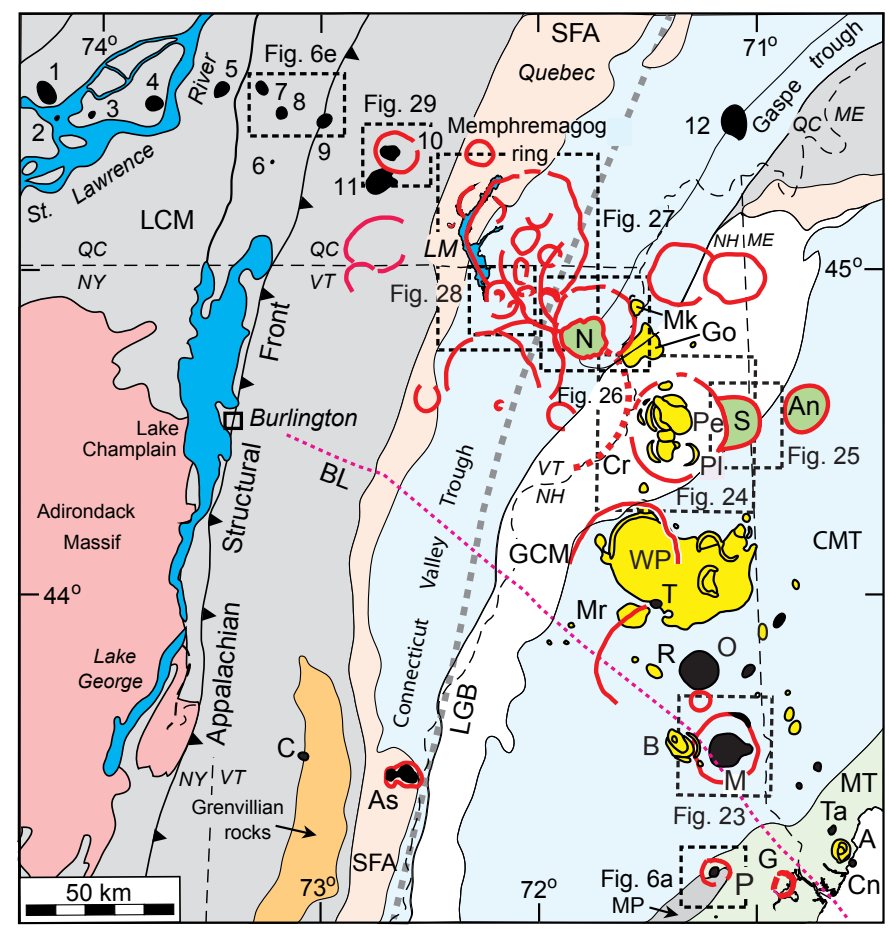

Figure 5. Location map of the WMMS and MHIP (dark blue patterns in southern Quebec). The black patterns in the southern part of the figure are Cretaceous intrusions and the yellow patterns are Jurassic intrusions of the WMMS. LGB (thick dashed grey line) is the eastern limit of Grenville basement. Ring-shaped depressions interpreted herein are shown with red contours. Abbreviations A, As, B, C, Cn, Go, M, Mk, Mr, O, P, Pe, Pl, R, Ta, and $\mathrm{T}$ are the Agamenticus, Ascutney, Belknap, Cuttingsville, Cape Neddick, Gore Mountain, Merrymeeting Lake, Monadnock, Mad River, Ossipee, Pawtuckaway, Percy, Pliny, Red Hill, Tatnic, and Tripyramid igneous complexes, respectively, and WP is the White Mountain pluton. G is the Great Bay ring-shaped depression. An, N, and S are the Andover, Nulhegan, and Success Hill topographic basins. LM is Lake Memphrémagog. $\mathrm{Cr}$ (dashed curve) is an interpreted partal ring-shaped depression along a curved segment of the Connecticut River valley. The dashed line labeled BL is the Burlington lineament of McHone and Shake (1992). Abbreviations of geologic units modified from Hibbard $e t$ al. (2006) are CMT (Central Maine trough), GCM (Ganderian continental margin rocks), LCM (Laurentian continental margin rocks), MP (Messabesic pluton), MT (Merrimack trough), and SFA (Shelburne Falls and other arcs of Laurentian affinity). The Monteregian Hills (numbered from 1-12) are: Oka (1), Cadieux (2), Bizard (3), Royal (4), St Bruno (5), St Gregoire (6), St Hilaire (7), Rougemont (8), Yamaska (9), Shefford (10), Brome (11), and Megantic (12). See Figure 1 for the location of this area.

the WMMS and NES include the Late Cretaceous to early Pleistocene coastal plain sediments, Pleistocene till and moraine deposits, Pleistocene to Holocene glaciomarine and marine deposits, and late Pleistocene glaciolacustrine 

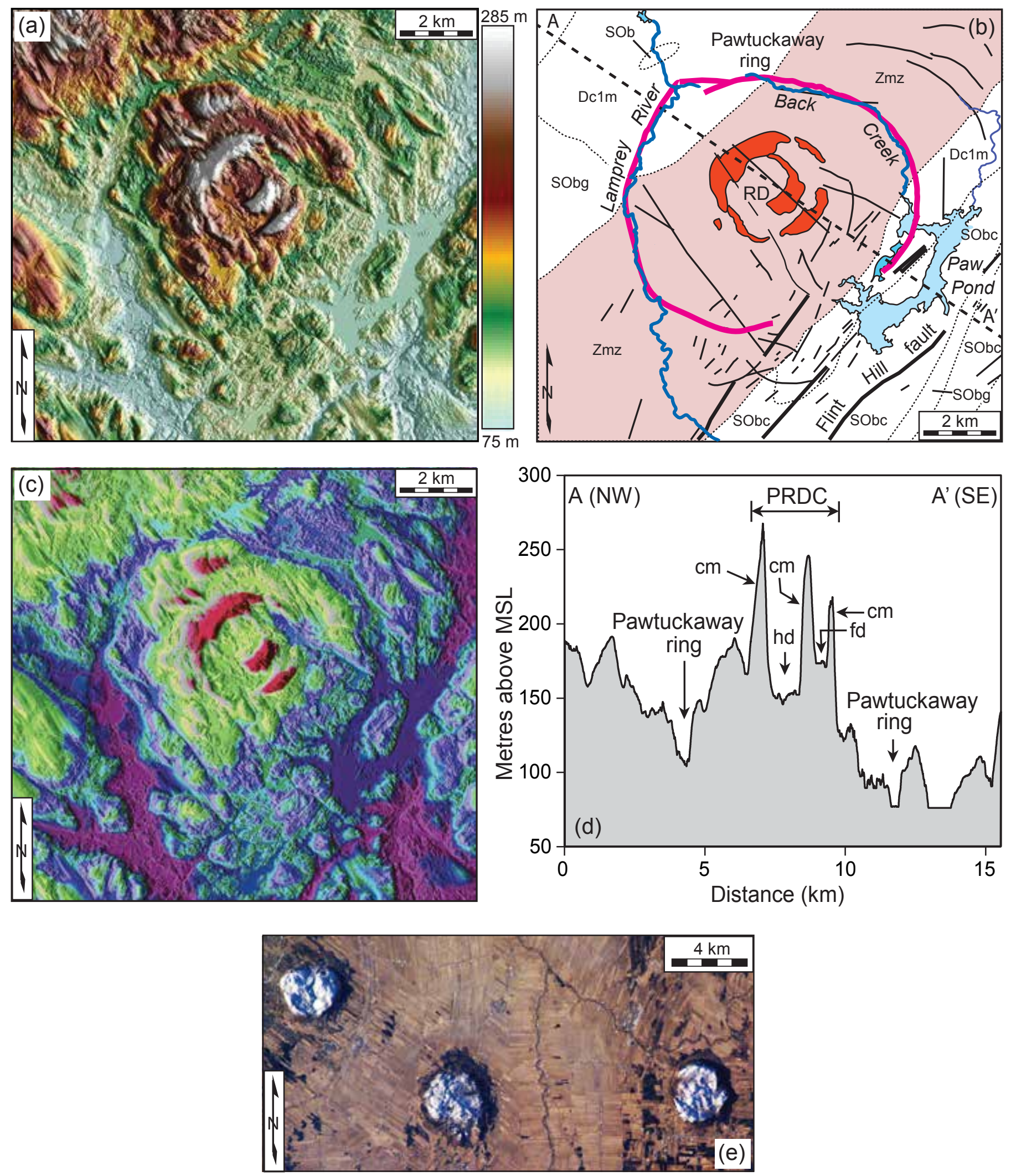

deposits (Uchupi and Bolmer 2008). The coastal plain sedi ments consist mainly of loose gravel, sand, silt, and clay that were deposited in the Gulf of Maine between Late Cretaceous time and the beginning of Pleistocene glaciation when the gulf was mostly above sea level (Uchupi and
Bolmer 2008). Most of these sediments were removed by Pleistocene glaciations and by episodes of fluvial erosion during major regressions in sea level during the late Eocene-early Oligocene, mid Miocene, latest Miocene, and late Pliocene (Uchupi and Bolmer 2008). 
Figure 6. (previous page) (a) LiDAR image of the Pawtuckaway ring that surrounds the Pawtuckaway ring dike complex. A color coded elevation index is located to the right of the image with maximum and minimum elevations in metres. See Figure 5 for the location of this image. (b) Interpreted drawing of (a). The red patterns labeled RD are the Pawtuckaway ring dikes. The dashed line labeled A- $A^{\prime}$ is the elevation profile shown in (d). The bedrock map units of Lyons et al. (1997) lie between fine dashed contours and are: Dc1m - grey two-mica granite unit of Concord granite, SOb - biotite-quartzfeldspar granofels or schist of Berwick formation, SObc - unnamed member of Berwick Formation with at least $15 \%$ calc-silicate minerals, SObg - Gove member of Berwick Fm, white muscovite schist, and Zmz - tan pattern, Massabesic Gneiss Complex. (c) IHS-enhanced version of (a). The colors represent elevations ranging from purple and blue for the lowest elevations, to yellowish-green for intermediate elevations, to red for the highest elevations. (d) Elevation profile across the ring dike complex with the following bedrock map units of Eby (1984b) shown: $\mathrm{cm}$ - coarse-grained monzonite, fd - foliated diorite, hd - hornblende diorite. PRDC (horizontal line) is the Pawtuckaway ring dike complex. (e) Satellite photo of (from left to right) Mont St. Hilare, Rougemont, and Mont Yamaska, which are three exposed igneous plugs that form small round, flat-topped mountains in the MHIP. Snow cover on these three mountains contrasts with the surrounding fallow, brown to tan colored agricultural fields. This photograph was taken from the International Space Station 18 April 2007 using a Kodak 760C digital camera. See Figure 5 for the location.

Overlying the coastal plain sediments are Pleistocene glacial sediments, which generally consist of till and glaciomarine facies (Bacchus 1993; Schnitker et al. 2001). The till is a poorly sorted mixture of gravel, sand, silt, and clay that was deposited on bedrock or remnants of the older coastal plain sediments. The glaciomarine facies that overlie the till consist of an upward-fining sequence of laminated pebbly mud, coarse-grained ice-rafted debris, gravelly sandy mud, and clayey silts (Bacchus 1993; Schnitker et al. 2001). Holocene deposits include clays that blanket much of the seafloor in the gulf, sand in the shallow water along the coast, and silts in the basins and estuaries along the coast (Uchupi and Bolmer 2008).

\section{Morphological features of the western Gulf of Maine and continental margin}

The seafloor beneath the Gulf of Maine is characterized by deep $(>200 \mathrm{~m})$ basins, low swells, irregular-crested ridges, and flat-topped banks and ledges (Uchupi 1968). This varied morphology is mainly the result of Pleistocene glaciations and episodes of fluvial erosion between the late Eocene and late Pliocene (Uchupi and Bolmer 2008). These processes eroded much of the coastal plain sediments beneath the Gulf of Maine and produced the submerged basins, such as Wilkinson Basin, and the ridge-like features, such as Jeffreys Ledge and Stellwagen Bank (Fig. 7), and the cuesta landform known as Georges Bank (Fig. 3) (Uchupi and Bolmer 2008).

\section{Stratigraphy under the continental margin southeast} of Nantucket Island, Massachusetts

The most prominent stratigraphic province under the continental shelf in the study area is Georges Bank Basin (Fig. 3), which consists of several subbasins filled with Jurassic through Paleogene synrift and postrift sediments that thicken seaward to over $10 \mathrm{~km}$ (Schlee and Klitgord 1988). The thickest deposits in the Georges Bank Basin are Jurassic and generally consist of evaporites near its base, overlain by carbonate and clastic sediments (Schlee and Klitgord 1988).
The Pleistocene sediments that overlie Georges Bank Basin are up to a few hundred metres thick and generally consist of gravel, sand, silty clay, clay, and sandy to clayey limestone (Uchupi and Bolmer 2008).

Georges Bank Basin is bounded on its seaward side by a Jurassic carbonate reef platform that is buried $\sim 1-1.5 \mathrm{~km}$ beneath the continental slope (Austin et al. 1980). Along the seaward side of the carbonate platform is a narrow, seaward-thickening, 500- to 600-m-thick sedimentary wedge that is heavily dissected by submarine canyons (e.g., Poag 1982; Pratson and Coakley 1996; Mitchell 2005). These upper continental rise deposits consist of carbonate debris from the seaward edge of the Jurassic platform that slumped seaward to form fan-shaped deposits and a thick onlapping wedge of Tertiary and Quaternary clay, claystone, and shale (Schlee et al. 1985). Within this sedimentary wedge are a series of smaller, discrete sedimentary packages that are bounded by laterally extensive unconformities (Uchupi et al. 1977; Uchupi and Austin 1979; Valentine 1981; Poag 1982; Schlee et al. 1985). One of the most prominent of these unconformities is the Paleocene unconformity denoted $\mathrm{A}^{\mathrm{u}}$ (Tucholke and Mountain 1979), which divides the Cenozoic section along the continental margin into three sedimentary packages: (1) sediment fill below $\mathrm{A}^{\mathrm{u}}$ but above the top of the Late Cretaceous sediments, (2) chaotic fill above $\mathrm{A}^{\mathrm{u}}$, and (3) widespread parallel-bedded fill that unconformably overlies the chaotic fill (Danforth and Schwab 1990).

\section{Correlation of stratigraphic units with seismic-reflection profiles}

Schlee and Klitgord (1988 and references therein) interpreted various stratigraphic units across seismic-reflection profiles that traversed the continental margin near the trend of the NES. From their investigation we interpreted two Jurassic horizons denoted $\mathrm{J}_{1}$ and $\mathrm{J}_{2}$ and an Upper Cretaceous horizon denoted $\mathrm{C}$ on our seismic-reflection profiles. $\mathrm{J}_{1}$ is a horizon at the top of the Upper Jurassic Cat Gap Formation, which is a red argillaceous limestone (Schlee and Klitgord 1988). $\mathrm{J}_{2}$ is a horizon at the top of the Middle Jurassic sediments (Schlee and Klitgord 1988). Horizon C (referred to 


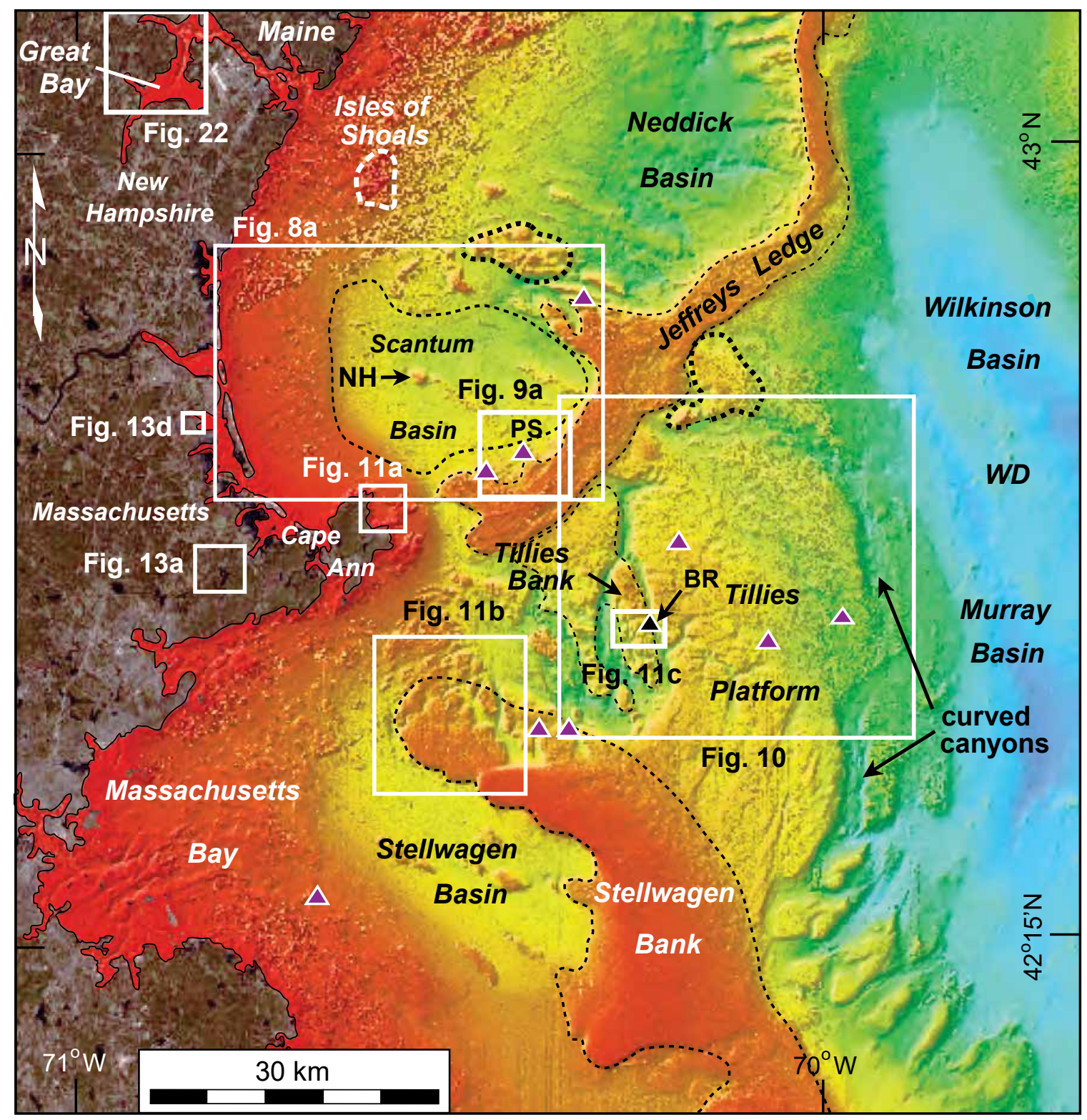

Figure 7. Digitally enhanced MBES image showing the physiographic provinces of the western Gulf of Maine (modified from Ward and Johnson 2016). WD is Wilkinson Divide. The purple triangles are interpreted small $(<2 \mathrm{~km}$ in diameter), submerged round, flat-topped hills or small hills with radiating ridges. NH is Newbury hill. PS is Petras star and BR is Boston roundtop.

as $\beta$ by Schlee and Klitgord 1988) marks the top of the Upper Cretaceous sediments. We also mapped the Paleocene unconformity A ${ }^{u}$ of Tucholke and Mountain (1979) on our seismic-reflection profiles where possible.

\section{OBSERVATIONS}

The following sections describe our observations in this study. Because of the size of the study area and abundance of interesting features, not all of them can be illustrated, but are summarized on Figures 2-5. Appropriate geographic names have been assigned to the more prominent and significant features.
Ring-shaped and other morphological features between coastal New Hampshire and the NES

The northernmost belt of ring-shaped morphological features recognized in the offshore area occurs between coastal New Hampshire and Cape Cod, MA, and is at least $100 \mathrm{~km}$ wide (Fig. 2). It also includes arc-shaped depressions and ridges onshore in northeastern Massachusetts. One of the more conspicuous of these rings occurs $\sim 17 \mathrm{~km}$ offshore from Hampton Falls, NH (Fig. 8a, top center). This Hampton Falls ring is a $\sim 1-\mathrm{km}$-wide ridge that is elliptical in shape, 7 by $9 \mathrm{~km}$ in size, and has up to $40 \mathrm{~m}$ of relief above the surrounding seafloor (Fig. 8c, profile 1). 
South of Hampton Falls ring are two opposing, arc-shaped scarps within Scantum Basin (Fig. 8a). The southwest-facing scarp on the east side of the basin is $5 \mathrm{~km}$ long and 3 to $4 \mathrm{~m}$ high (Fig. 8c, profile 5). Along the base of this scarp is a 5-km-long, 6- to 8-m-deep and $\sim 100$-m-wide depression in the seafloor. Southwest of this curved scarp is a NE-SWoriented dendritic pattern of depressions (up to $9 \mathrm{~m}$ deep) that terminates northeastward against the scarp (Figs. 8a and $8 \mathrm{c}$, profile 6 ). The gently sloping, east-facing, arc-shaped scarp to the southwest has a relief of $\sim 20 \mathrm{~m}$ above the surrounding seafloor (Fig. 8c, profiles 2 and 3). Centered between these two scarps is a $2.5-\mathrm{km}$-wide, 60 -m-high circular hill, herein named Newberry hill (Figs. $8 \mathrm{a}$ and $8 \mathrm{c}$, profiles 2-4). The circular shape of Newbury hill resembles that of some of the Monteregian Hills (Fig. 6e).

Trending southeast away from Newberry hill is a submerged, 30-m-high, 11-km-long ridge that terminates along a $\sim 5.5-\mathrm{km}$-diameter, arc-shaped depression that is slightly (2-4 m) lower than the surrounding seafloor (Fig. 8). Within this subtle depression is a $\sim 1.8-\mathrm{km}$-size, star-shaped feature in the seafloor that we have named Petras star (Fig. 9a). The central area of Petras star is $\sim 13 \mathrm{~m}$ higher than the surrounding seafloor and is surrounded by six ridges that radiate outward.

Southeast of Petras star and $\sim 20 \mathrm{~km}$ east of Cape Ann is a pair of concentric, ring-shaped depressions, the outer ring of which is the largest ring-shaped morphological feature in the western Gulf of Maine (Fig. 10) (Marple et al. 2015). The $35-\mathrm{km}$-diameter outer ring, herein named Tillies ring, is an arc-shaped, $1.5-$ to $2.5-\mathrm{km}$-wide depression. Tillies ring is best expressed bathymetrically to the north and east as an arc-shaped depression in the seafloor that is as much as $45 \mathrm{~m}$ deep (Figs. 10c and 10d). The western side of the outer ring is not as smooth and arc-like as the northern and eastern sides of the ring and is formed by the NNW-SSE-oriented canyons that form part of Tillies Basin. The $\sim 10-\mathrm{km}$-diameter, $\sim 800$-m-wide inner ring is also a depression (Fig. 10a) (Marple et al. 2015). The depth of the inner ring beneath the seafloor ranges from only $4 \mathrm{~m}$ to the west to as much as $23 \mathrm{~m}$ to the east (Fig. 10b). The seafloor inside the Tillies outer and inner rings is hummocky in many places with submerged hills that are as high as $15 \mathrm{~m}$ above the surrounding seafloor and as wide as $300 \mathrm{~m}$.

Approximately $10 \mathrm{~km}$ east of Tillies outer ring is the curved, 2- to 3-km-wide Murray Basin that appears to be continuous with one of the curved short canyons southeast of Tillies Platform (Fig. 7). The arc-shaped Murray Basin surrounds the east side of Tillies ring (Fig. 7). Murray Basin, therefore, appears to be part of an arc-shaped depression that is considerably larger than the Tillies outer ring. Other curved canyons occur southeast of Tillies ring (Fig. 7).

Near the coast of Cape Ann, MA, is a $2-\mathrm{km}$-long, arcshaped submarine ridge that is located along the eastern side of Pigeon Cove (Fig. 11a). It is $\sim 100 \mathrm{~m}$ wide and elevated at least $16 \mathrm{~m}$ above the seafloor in Pigeon Cove. We have named this feature Pigeon Cove ring. South-southeast of Pigeon Cove ring is a circular, 11-km-wide, bathymet- rically high area at the northwest end of Stellwagen Bank (Fig. 11b). It is $\sim 40 \mathrm{~m}$ above the seafloor to the southwest and is bounded on the west and east by 4 - to 5 - $\mathrm{km}$-long arcshaped depressions (Fig. 11b). The depression to the west is $\sim 500 \mathrm{~m}$ wide and up to $20 \mathrm{~m}$ deep and the depression to the east is $\sim 1 \mathrm{~km}$ wide and up to $60 \mathrm{~m}$ deep.

Along the southwestern rim of Tillies ring is a 100- to 200-m-wide, 5-km-long, elliptical-shaped depression in the seafloor (Figs. 7 and 11c). A distinct 400-m-wide, flattopped circular hill occurs near its northeast rim (Fig. 11e). The submerged hill, which we have named Boston roundtop, is as much as $50 \mathrm{~m}$ above the surrounding seafloor (Fig. 11f). Other similar circular hilltops that rise above the surrounding seafloor were mapped inside this ring and at other locations in the western Gulf of Maine (Fig. 7).

Northeast of Tillies ring are a few subtle, ring-shaped depressions (Fig. 3). The image quality of these rings is lower than that of those to the west because of the coarser $(8 \mathrm{~m})$ resolution of the data in this area. East of these rings and near Cashes Ledge is a curved 100-km-long, discontinuous series of NW-facing scarps with 20 to $25 \mathrm{~m}$ of relief above the seafloor to the northwest (Fig. 12c), which we have named Cashes scarp. Northwest of this scarp is a 20- to 25-km-wide, 20-m-deep Cashes depression (Fig. 12b). Northwest of Cashes scarp and depression is the largest (80-km-long, 42-km-wide) positive magnetic anomaly in the western Gulf of Maine, herein named the Cashes magnetic anomaly (Fig. 12b).

Elliptical- and arc-shaped depressions and ridges were also identified onshore in northeastern Massachusetts. One of these rings occurs west of Cape Ann at site $\mathrm{H}$ in Figure 2. This $3.2 \times 4.7-\mathrm{km}$-size, NE-SW-oriented, elliptical-shaped depression surrounds an area of relatively high terrain (Fig. 13a). The narrow ( $<1.5-\mathrm{km}$-wide) depression surrounding most of this high terrain is up to $15 \mathrm{~m}$ deep (Fig. 13c). The highest terrain inside this ring-shaped depression, named the Essex ring, appears to be associated with drumlins. Just north of the Essex ring in northeastern Massachusetts is a 2-km-long arc-shaped ridge, herein named the Parker River ring (Fig. 13d). The surficial geologic map of Stone et al. (2006) shows that this ridge is covered by marine regressive and glacial stratified deposits.

The second belt of rings offshore occurs southeast of Cape Cod (Fig. 3). The northernmost ring in this belt is located $\sim 17 \mathrm{~km}$ east of Cape Cod (Fig. 14a) and is defined by a 13-km-long, 2- to 4-km-wide, arc-shaped alignment of several bathymetrically high areas that are elevated as much as $47 \mathrm{~m}$ above the surrounding seafloor. We have named this feature the Cape Cod ring. The long axis of this partial ring is oriented NNE-SSW. The relief along this discontinuous ridge decreases to the southwest where the seafloor becomes more shallow. Southwest of this feature and $\sim 12 \mathrm{~km}$ northeast of Nantucket Island is a 1 - to $2-\mathrm{km}$-wide, $\sim 19-\mathrm{km}$ diameter, ring-shaped depression, herein named the Nantucket ring, that is at least $19 \mathrm{~m}$ deep (Figs. 14c-14e).

Approximately $50 \mathrm{~km}$ east of Nantucket Island is a $26-\mathrm{km}$ long, 2.5-km-wide arc-shaped ring along the west side of 

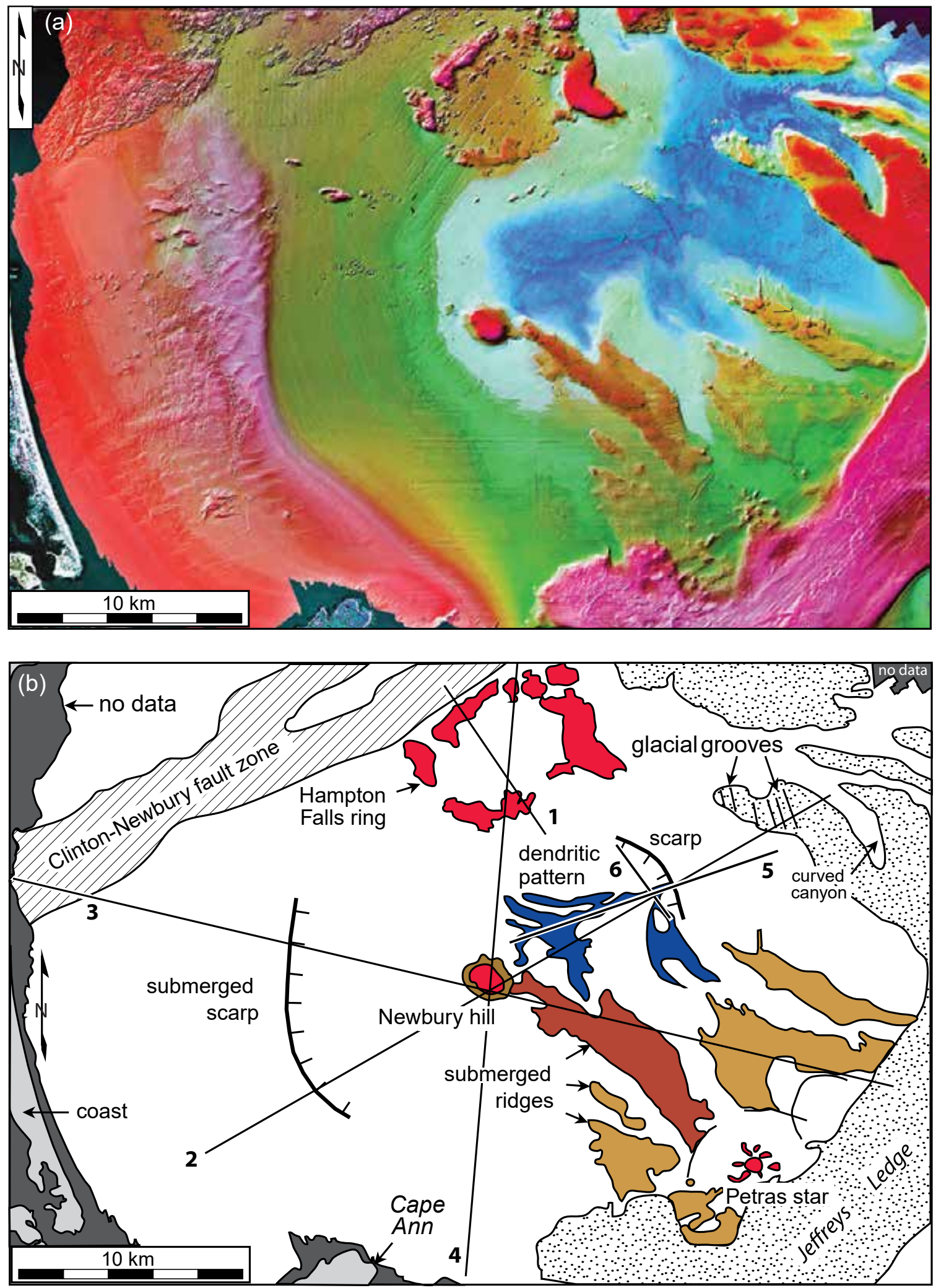

Figure 8. (a) IHS-enhanced MBES image of Scantum Basin. Colors represent water depths ranging from blue for the deepest areas to red for the shallowest water depths. See Figure 2 for the location of this figure. (b) Interpreted drawing of (a). Lines labeled 1-6 are bathymetric profiles that are shown in (c, next page). Submerged scarps are shown by curved lines with tics on the down side. The dark blue pattern northeast of Newberry hill is a dendritic pattern of depressions in the seafloor. (c) (next page) Bathymetric profiles traversing various features in Scantum Basin. The vertical exaggeration $(\mathrm{VE})=$ 88 for profile 1, 222 for profiles 2-4, 410 for profile 5, and 375 for profile 6 . 

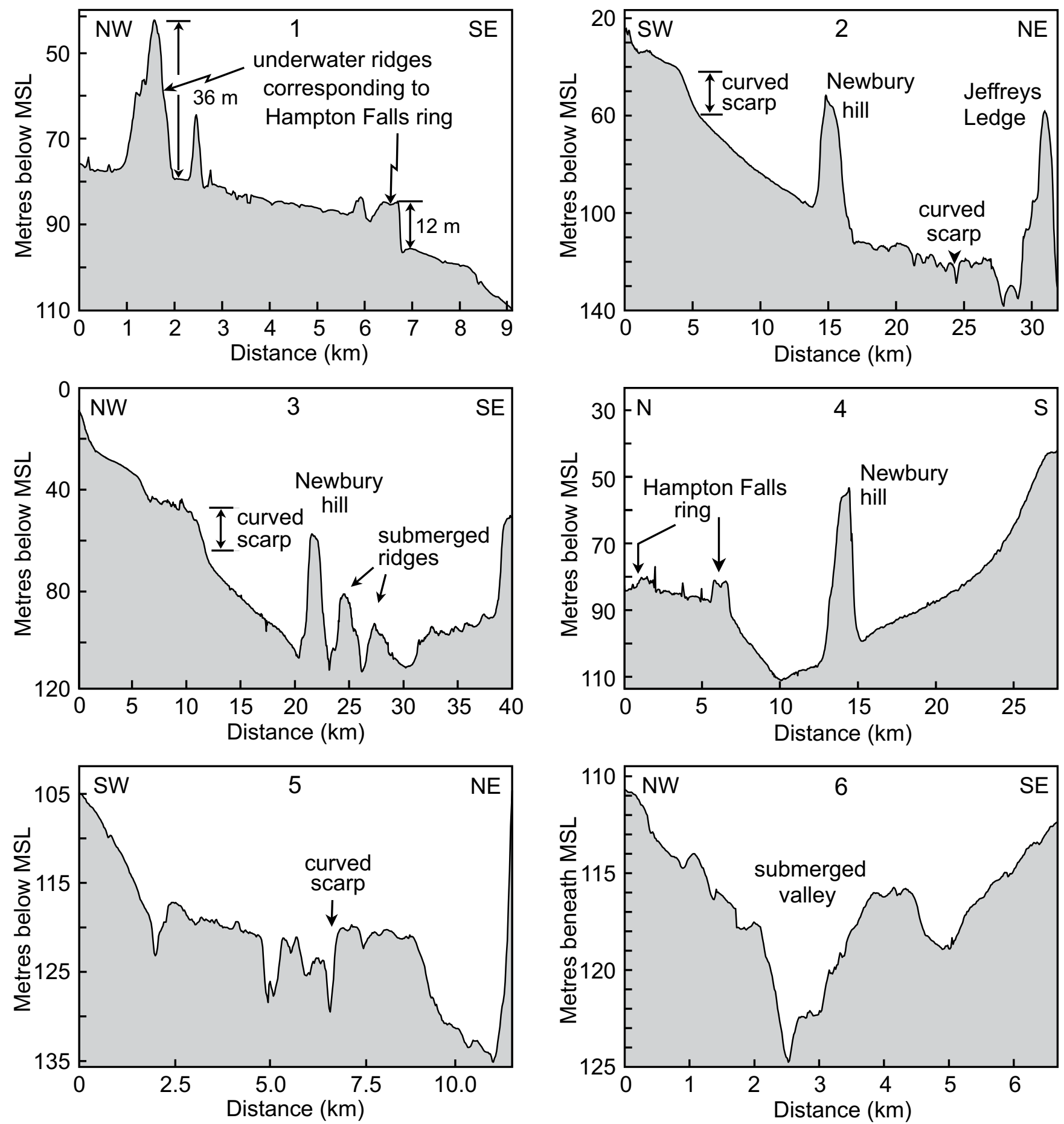

the Great South Channel where it curves eastward (Figs. 3 and 14f). No digital MBES data are available for this area to determine whether this ring is a depression or a ridge. Other partial rings located southeast of Cape Cod are also shown in Figure 3.

The third belt of ring-shaped features offshore traverses the outer continental shelf, continental slope, and upper continental rise (Fig. 3). Some of these rings are large (up to $\sim 50 \mathrm{~km}$ in diameter) and a few are defined by curved submarine canyons on the continental slope and outer shelf. For example, a $\sim 50-\mathrm{km}$-diameter, 3- to 5-km-wide ring formed

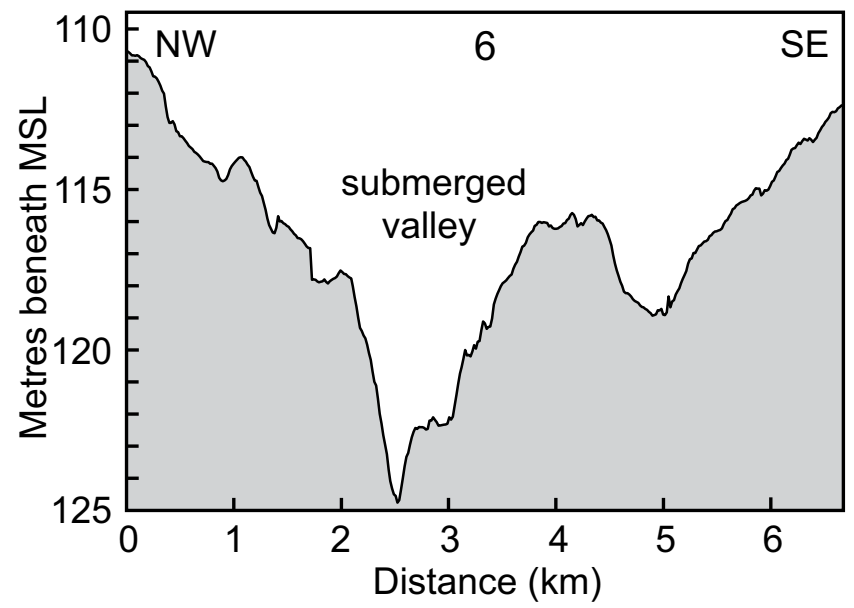

by two curved unnamed canyons on the upper continental rise west of Bear Seamount (Fig. 15a). The curved canyon on the east side is as much as $55 \mathrm{~m}$ deep (Fig. 15c). The curved nature of these canyons contrasts with the straighter canyons that traverse the continental slope away from the trend of the NES.

North of this area is a 9.5-km-long partial ring on the continental slope that is formed by the curved part of a submarine canyon and two short curved ridges (Fig. 15d). Along its southern margin is a $\sim 3.2-\mathrm{km}$-size seamount or volcanic neck (Figs. 15d-15f, site V1). The pattern of 

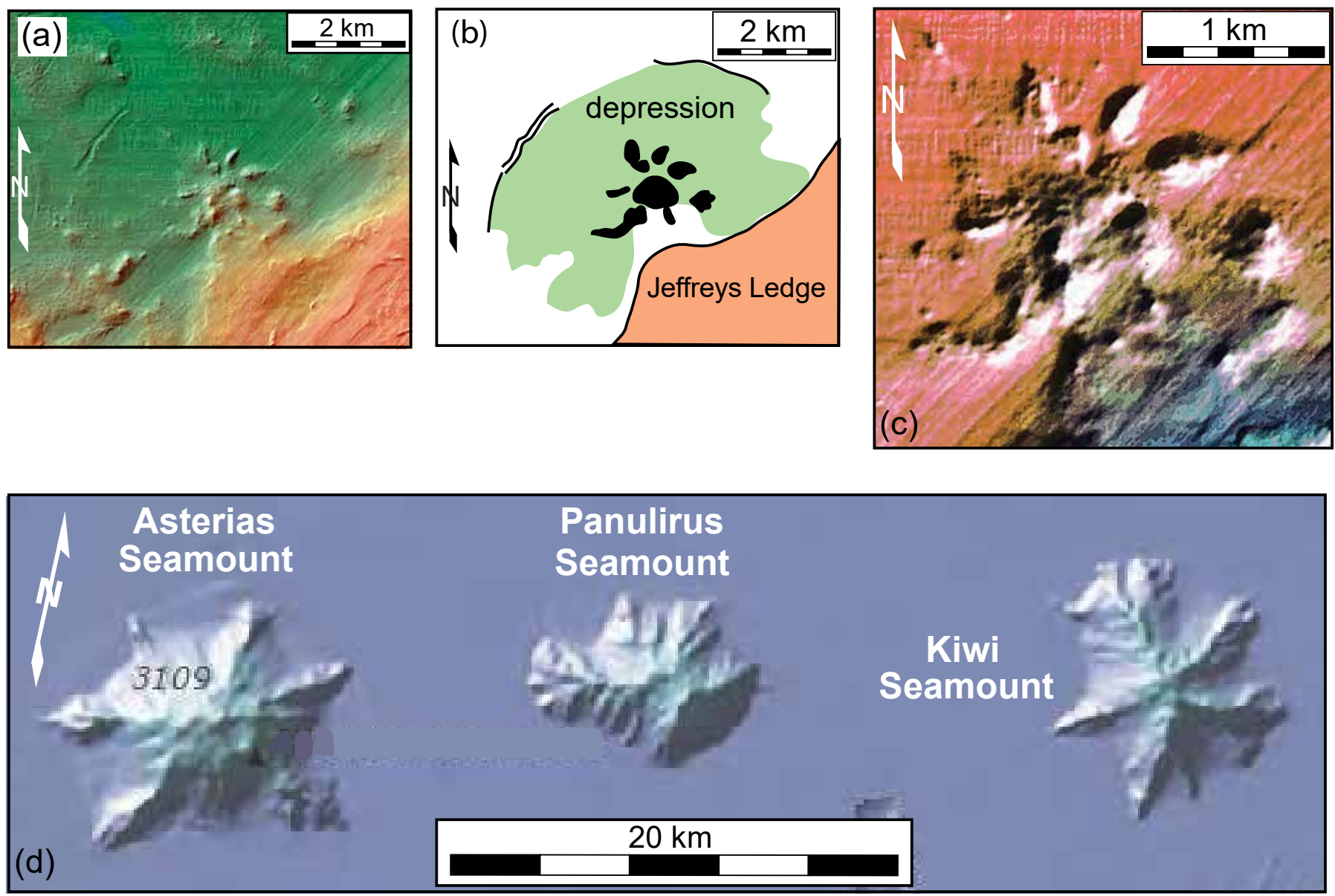

Figure 9. (a) MBES image of Petra's star northeast of Cape Ann. See Figure 2 for the location of this feature. (b) Interpreted drawing of (a). (c) Enlarged version of (a). (d) Examples of star-shaped New England seamounts. See Figure 1 for the location of these seamounts.

NW-SE-trending ridges on the continental slope is interrupted by this partial ring, as shown on Figure 15d. A bathymetric profile across the small seamount shows that its southern flank is at least $185 \mathrm{~m}$ above the seafloor (Fig. 15f). Seismic-reflection profile 129 in Figure 16 shows the interpreted intrusion associated with this seamount, as well as other intrusions beneath the continental slope and rise. The Upper Jurassic and Upper Cretaceous horizons labeled $\mathrm{J}_{1}$ and $\mathrm{C}$ on this profile are truncated by these intrusions (Fig. 16). Approximately $6 \mathrm{~km}$ northeast of this seamount, a 3-km-diameter, star-shaped feature has ridges radiating outward away from its center (Fig. 15e, site V2). Its shape resembles that of some of the New England seamounts (Fig. 9d).

East of these seamounts and on the continental slope is a partial ring formed by two, 5- to 7-km-wide, 30 - to $35-\mathrm{km}$ long, arc-shaped canyons (Fig. 15g). Powell Canyon forms the west side of this ring and an unnamed canyon forms the east side. The partial ring formed by these two canyons is $\sim 40 \mathrm{~km}$ in diameter. A 2D bathymetric profile across the unnamed canyon to the east is up to $140 \mathrm{~m}$ deep (Fig. 15i).

A faint, $\sim 10-\mathrm{km}$-diameter complete ring and two concentric, arc-shaped depressions are located southwest of Bear
Seamount (Fig. 15j). The complete ring is characterized by a 2- to $2.5-\mathrm{km}$-wide circular depression up to $24 \mathrm{~m}$ deep (Fig. 15l) that is faintly visible near the northwestern corner of Figure 15j. Southeast of the complete ring are two curved depressions that are transverse to the southeast-downward gradient of the continental slope (Fig. 15j). The larger, 35 -km-long depression is $\sim 4 \mathrm{~km}$ wide and $\sim 125 \mathrm{~m}$ deep (Fig. $15 \mathrm{~m}$ ).

West of Bear Seamount, the Oceanographer and Gilbert canyons curve around a bathymetrically high area (Fig. 17). The curved part of Gilbert Canyon to the northeast truncates the western edge of Bear Seamount and Oceanographer Canyon to the southwest curves to the northeast where it truncates the bathymetrically high area between the two canyons (Fig. 17). The MBES image also revealed a NNWSSE-trending, east-facing scarp that bisects this area. This scarp has up to $70 \mathrm{~m}$ of relief across its southern end (Fig. 17 c, profile 4). Toward the northwest side of the area between the two canyons is a $\sim 10-\mathrm{km}$-wide area that is at least $140 \mathrm{~m}$ higher than the surrounding sea floor (Figs. 17b, pattern $\mathrm{BH}$, and 18, between shotpoints 3820 and 4200 ). It is also bisected by the scarp (Fig. 17b). Near the northeastern edge of the local high in the seafloor and bordering Gilbert 

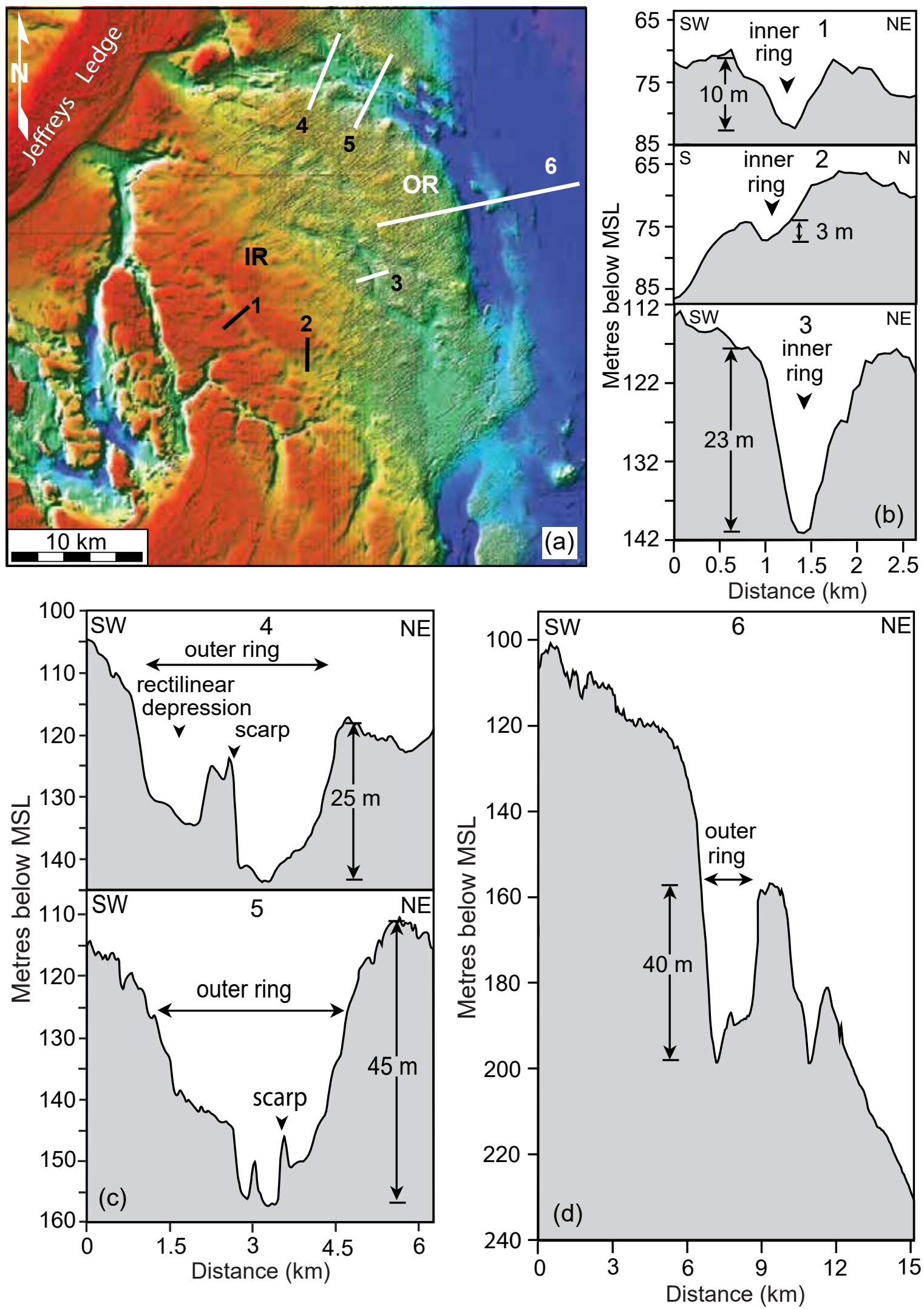

Figure 10. (a) Color MBES image revealing two concentric ring-shaped depressions in the seafloor east of Cape Ann, MA. Tillies ring is the larger, more conspicuous outer ring denoted OR while the more subtle inner ring is denoted IR. Dark blue areas are the deepest areas while the red patterns are the shallowest areas. See Figure 7 for the location of this diagram. (b) Bathymetric profiles across the inner ring. $\mathrm{VE}=68$. (c) Bathymetric profiles across the northern part of the Tillies outer ring. $\mathrm{VE}=93$. (d) Bathymetric profile across the northeastern part of the Tillies outer ring. $\mathrm{VE}=183$. 

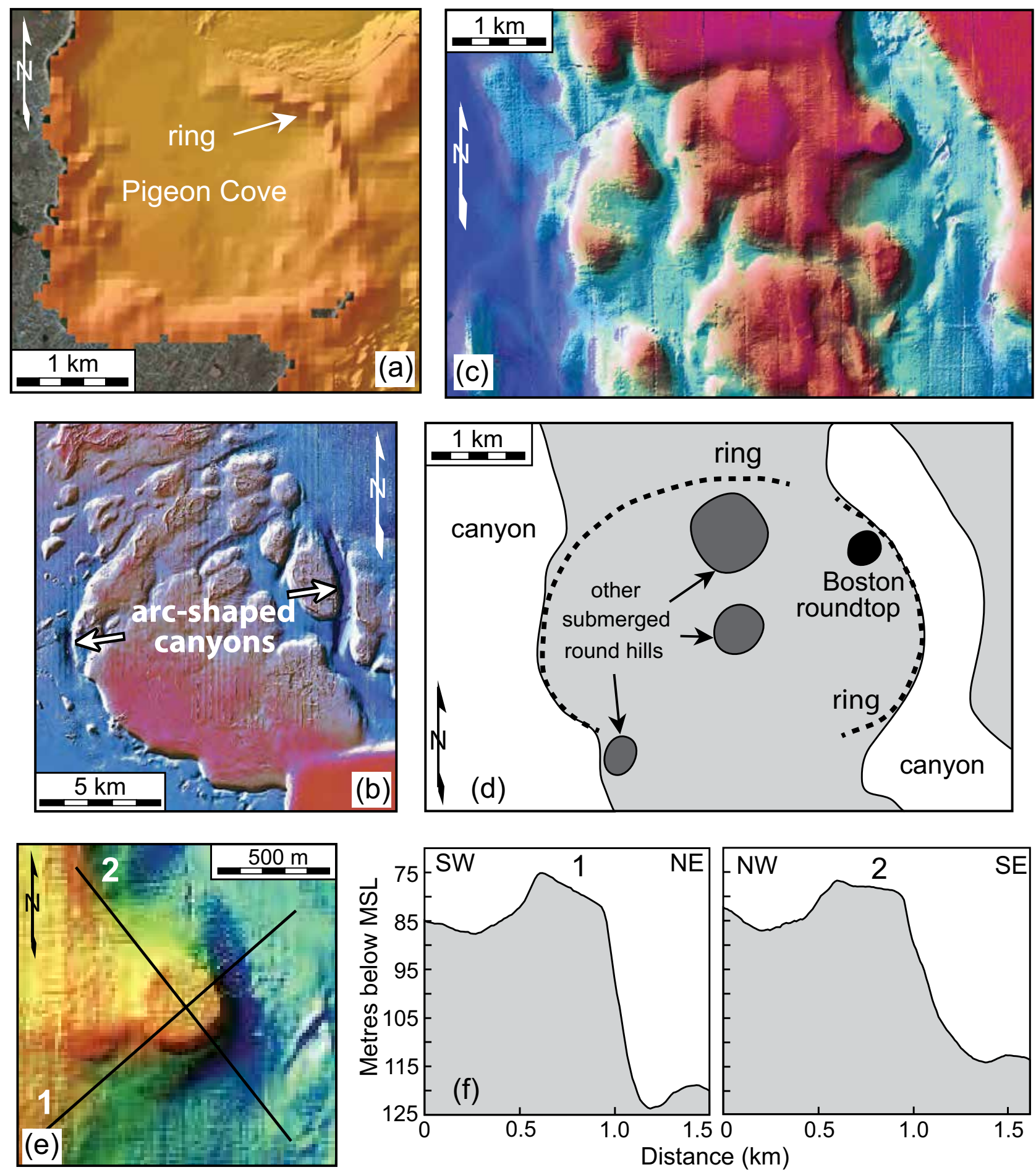

Figure 11. (a) Sonar image revealing curved ridge referred to as Pigeon Cove ring. See site $\mathrm{E}$ in Figure 2 for the location of this feature. (b) Circular, bathymetrically high area at the northwest end of Stellwagen Bank with arc-shaped depressions along its east and west sides. See site F in Figure 2 for the location of this feature. (c) IHS-enhanced MBES image showing elliptical-shaped depression with a small ( $400 \mathrm{~m}$ wide), circular, flat-topped hill along its eastern margin (Boston roundtop). (d) Interpreted drawing of (c). (e) IHS-enhanced MBES image of Boston roundtop. Colors represent varying water depths ranging from dark blue for the greatest depths to light brown for the shallowest water depths. See site $\mathrm{G}$ in Figure 2 for the location of this feature. (f) Bathymetric profiles across Boston roundtop (VE $=25)$.

Canyon is a curved ridge with up to $180 \mathrm{~m}$ of relief (Figs. $17 \mathrm{~b}$, pattern CR, and 17c, profiles 1 and 2). Examination of seismic-reflection profile $28 \mathrm{X} 2$ revealed an intrusion and upwarped strata at depth beneath this bathymetrically high area and a south-plunging, dome-shaped feature above the interpreted Upper Cretaceous C horizon at $\sim 5 \mathrm{sec}$ TWTT 

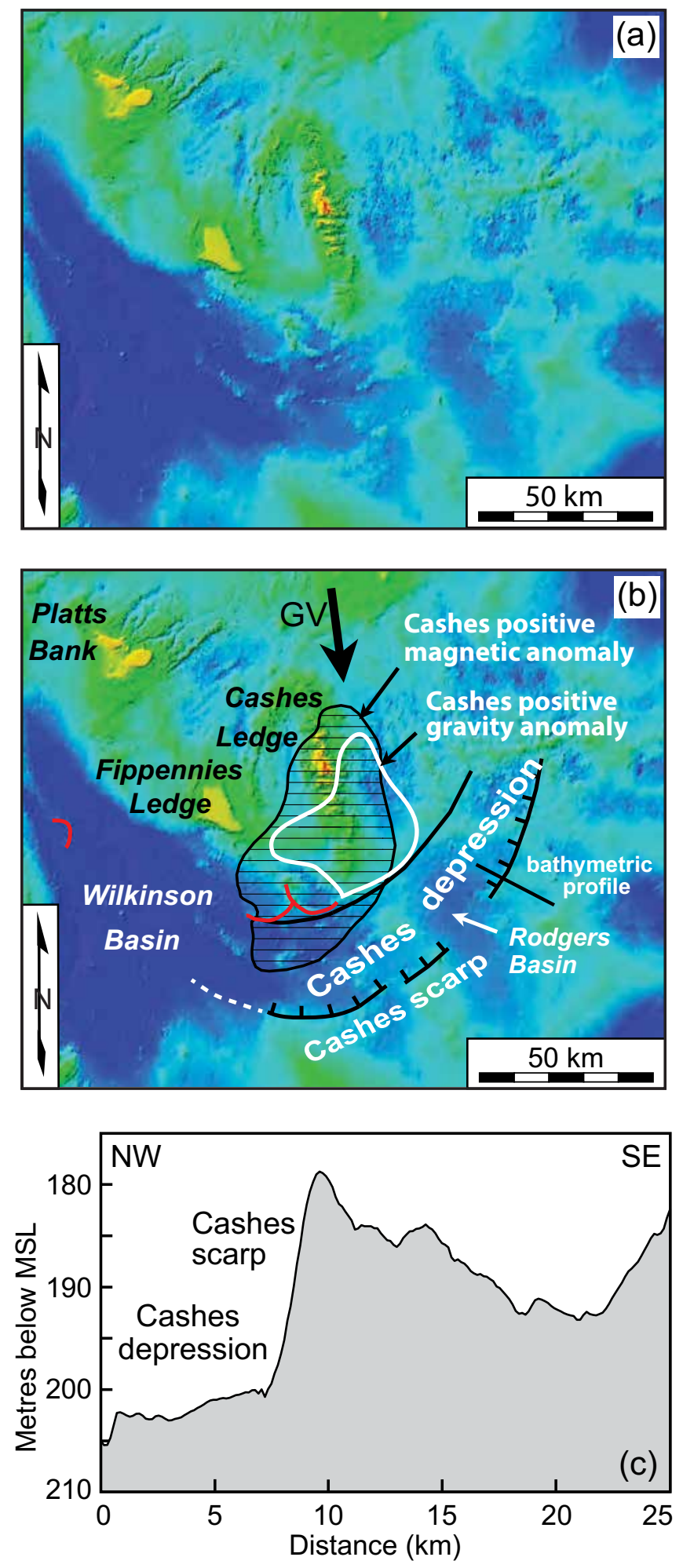

(two-way travel time) (Fig. 18). The dome on profile 28X2 narrows upward through the overlying sediments to the seafloor where it forms a $1.5-\mathrm{km}$-wide, mound-like feature with $\sim 100 \mathrm{msec}$ TWTT of relief (Fig. 18). This mound also coincides with the NNW-SSE-oriented scarp that bisects the area between the two canyons (Fig. 17, site V3). It is uncertain whether this feature is a small seamount or part of a dike. Northeast of this mound and near shotpoint 3580 of
Figure 12. (a) MBES image of the western Gulf of Maine east of Cape Ann, MA. The colors represent varying water depths ranging from dark blue for the greatest water depths, to light blue and green for intermediate depths, and then yellow and red for the shallowest depths. See Figure 3 for the location of this area. (b) Interpreted version of (a). The Cashes depression is the area between Cashes scarp (ticks on downthrown side) and the black contour northwest of Cashes scarp). The Cashes positive gravity (white contour) and magnetic (striped pattern) anomalies are interpreted from Figures 31 and 32. The NW-SEoriented line across Cashes scarp is the location of the bathymetric profile shown in (c). The solid arrow labeled $\mathrm{GV}$ is the general south-southeast direction of the Laurentide ice sheet. (c) Bathymetric profile across Cashes scarp.

Figure 18 is the arc-shaped submarine ridge (CR) along the southwest side of Gilbert Canyon (Fig. 17b).

Just east of the Gilbert Canyon is the most northwestern of theNES, BearSeamount, which formed on the southeastwardsloping upper continental rise (Figs. 19a-19c). Surrounding Bear Seamount are morphological features that suggest that it is centered within a $65-\mathrm{km}$-long, $40-\mathrm{km}$-wide, bathymetrically high area in the seafloor (Fig. 19b, blue pattern). First, the Lydonia and Powell canyons north of Bear Seamount bend abruptly away from the area between the two canyons (Fig. 19b). Secondly, $\sim 30 \mathrm{~km}$ south of the seamount and surrounding its southern flank is a gently sloping, south-facing, arc-shaped scarp (Fig. 19b) that is up to $250 \mathrm{~m}$ higher than the seafloor to the south (Fig. 19c). Bisecting the area between the two canyon bends and Bear Seamount is a NNW-SSE-oriented, 3- to 5-km-wide, 30-kmlong ridge that is at least $30 \mathrm{~m}$ higher than the surrounding seafloor (Figs. 19a and 19d, profile 3). The east side of this ridge is bounded by a gently sloping, east-facing scarp that has up to $200 \mathrm{~m}$ of relief above the seafloor to the east (Fig. $19 \mathrm{~d}$, profiles 2 and 3 ). The ridge and scarp traverses the east flank of Bear Seamount (Fig. 19a). Interpretation of seismicreflection profile $28 \mathrm{X} 2$ revealed that this area is underlain by a $35-\mathrm{km}$-wide zone of upwarped Cenozoic and older strata (Fig. 20). The apex of the uplifted strata at $6 \mathrm{sec}$ TWTT lies directly below the NNW-SSE-trending ridge north of Bear Seamount (Fig. 20). An interpreted igneous intrusion lies below the upwarped sediments at $\sim 6 \mathrm{sec}$ TWTT. The pattern of colors along the seafloor immediately east of the seamount is interpreted to be landslide debris from partial collapse of the seamount's eastern flank along the eastfacing scarp. This scarp continues south of Bear Seamount, although without a ridge along its crest, yielding a total length of $\sim 60 \mathrm{~km}$ for the scarp (Fig. 19). The relief on the southern scarp is $75 \mathrm{~m}$ (Fig. 19d, profile 4), which is less than that along the scarp north of Bear Seamount. The MBES image in Figure 19a and the bathymetric profile across Bear Seamount (Fig. 19c) also revealed that its southern flank has partially slumped.

Approximately $60 \mathrm{~km}$ southeast of Bear Seamount is a partial ring formed by an E-W-oriented, 13-km-long, 

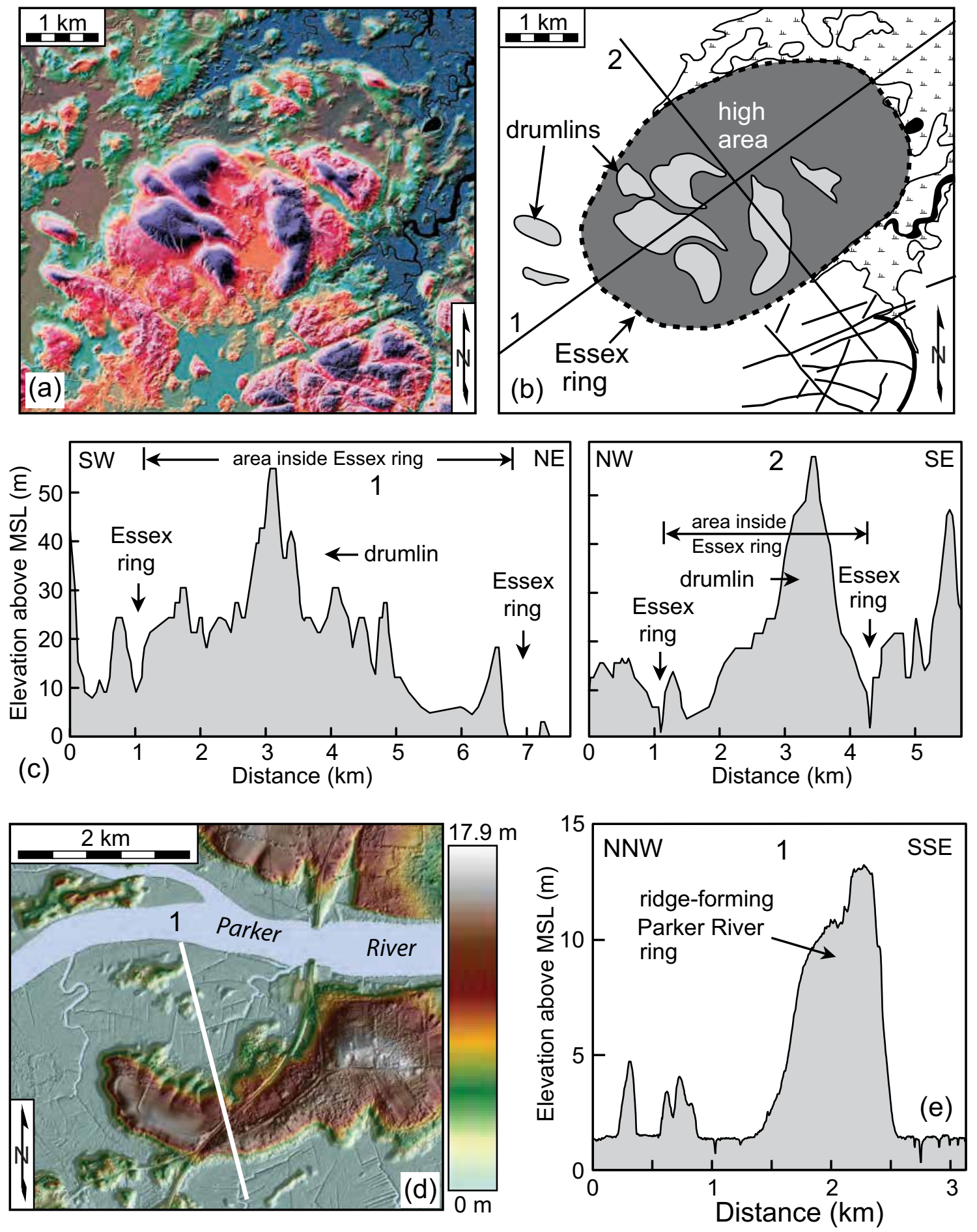

Figure 13. Lidar images of ring-shaped morphological features in northeastern Massachusetts. (a) IHS-enhanced LiDAR image just west of Cape Ann, MA. The different colors represent varying elevations ranging from black and blue for the lowest elevations, to dark brown, green, and red for the intermediate elevations, to dark purple for the highest elevations. (b) Interpreted drawing of (a). (c) Topographic profiles across the elliptical-shaped feature in (a). VE = 67. See site $\mathrm{H}$ in Figure 2 for the location of this feature. (d) LiDAR image showing an arc-shaped ridge in northeastern Massachusetts. The white line labeled 1 is the location of the elevation profile in (e). See Figure 7 for the locations of the features in (a) and (d). (e) Elevation profile across the arc-shaped ridge in (d).

1-km-wide curved ridge along the crest of Mytilus Seamount that merges to the east with a curved, 7-km-long, north-south-oriented, east-facing scarp (Fig. 21). Mytilus
Seamount rises $\sim 1500 \mathrm{~m}$ above the surrounding seafloor along this ring-shaped feature, herein named the Mytilus ring (Fig. 21c, profiles 2 and 3). The curved ridge has 30 to 
$50 \mathrm{~m}$ of relief above the flanks of the seamount, suggesting that it may be part of a ring dike (Fig. 21c, profiles 3 and 5). The east-facing scarp to the northeast has up to $70 \mathrm{~m}$ of relief (Fig. 21c, profile 1). Projecting northward from the northern flank of the seamount is a $\sim 15-\mathrm{km}$-long, north-southoriented linear ridge (Fig. 21a) that is at least $1.5 \mathrm{~km}$ wide near its crest and has at least $150 \mathrm{~m}$ of relief above the seafloor to the west (Fig. 21c, profiles 1, 2, and 4). Profiles 1, 2, and 4 of Figure $21 \mathrm{c}$ also show that the seafloor west of this ridge is $\sim 250 \mathrm{~m}$ higher than the seafloor above the curved scarp to the east. The relief across this ridge decreases northward away from Mytilus Seamount.

\section{Ring-shaped depressions between the MHIP and WMMS}

The second part of our study was to determine if morphological features like those offshore exist onshore between the MHIP and WMMS. Our investigation of this area revealed several ring-shaped depressions along this trend, some of which surround mapped igneous intrusions (Fig. 5). The most southern ring in this area is the 7-km-diameter Great Bay ring, first identified by Marple and Altamura (2015a). It is formed by the curved segments of the Oyster and Lamprey rivers, Little Bay, and a curved portion of a submerged channel along the west side of Great Bay (GB) (Fig. 22).

Approximately $8 \mathrm{~km}$ west of the Great Bay ring is a $\sim 7.5-\mathrm{km}$-diameter, $\sim 0.5-\mathrm{km}$-wide, ring-shaped depression that surrounds most of the $3-\mathrm{km}$-diameter, Cretaceous Pawtuckaway ring dike complex in southeastern New Hampshire, which we have named the Pawtuckaway ring (Fig. 6a). The Pawtuckaway ring is a ring-shaped depression formed partly by a curved segment of the Lamprey River valley to the southwest and the curved Back Creek valley to the northeast (Fig. $6 \mathrm{~b}$ ). The ridge-forming ring dikes in the center of the Pawtuckaway ring are composed of relatively resistant monzonite and syenite whereas the more easily eroded diorite ring dikes underlie the lowlands (Eby 1995). The area inside the Pawtuckaway ring is $\sim 50 \mathrm{~m}$ higher than the surrounding area (Fig. 6d), although some of this relief may be from Pleistocene till.

The 10- to $15-\mathrm{km}$-wide, Cretaceous Merrymeeting Lake igneous intrusive complex is $\sim 38 \mathrm{~km}$ north of the Pawtuckaway ring dike complex (Fig. 5). Like the latter, the Merrymeeting Lake intrusive complex is almost completely surrounded by a $20-\mathrm{km}$-diameter, 2 - to $3-\mathrm{km}$-wide, ringshaped depression, herein named the Winnipesaukee ring, that is formed by the divergence of Lake Winnipesaukee around the northwest side of this area, Lake Wentworth, the Merrymeeting River valley, and other depressions (Fig. 23). A curved, 7-km-long igneous formation (unit K1a) coincides with a northeastern segment of the Winnipesaukee ring (Fig. 23b).

An even larger, $\sim 32-\mathrm{km}$-diameter, 500-m-wide, ringshaped depression surrounds the Jurassic Pliny and Percy ring dike complexes in northern New Hampshire (Fig. 24). This ring, herein named the Pliny ring, is mainly formed by
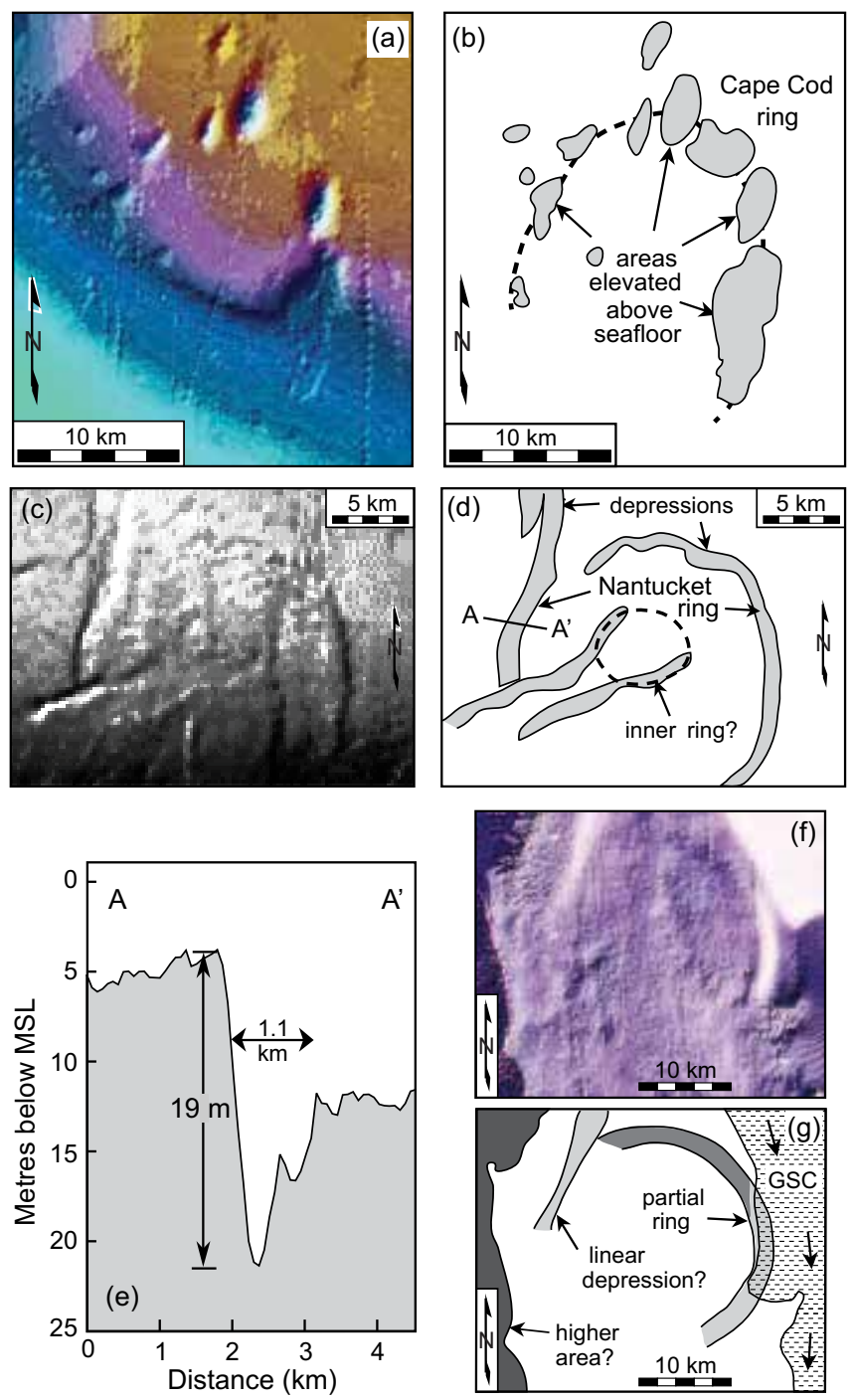

Figure 14. Sonar images of partial rings located between Cape Cod and the New England seamounts. (a) IHSenhanced MBES image showing a partial ring consisting of a series of bathymetrically high areas east of Cape Cod. Water depths deepen from southwest to northeast. (b) Interpreted drawing of (a). (c) Sonar image of the Nantucket ring northeast of Nantucket Island. (d) Interpreted drawing of (c). (e) Bathymetric profile across the west side of the Nantucket ring $(\mathrm{VE}=141)$. (f) Digitally enhanced sonar image of a submerged partial ring along the west side of the Great South Channel (GSC). (g) Interpreted drawing of (f). The sonar images in these diagrams were taken from UNH/CCOM-JHC (2015a). See Figure 3 for the locations of these rings.

curved segments of the Israel, Androscoggin, and Moose rivers (Fig. 24b). A Jurassic igneous intrusion (unit Jc1b), 4 by $8 \mathrm{~km}$ in size, and a 7-km-long curved ridge coincide with the northern rim of the Pliny ring (Fig. 24).

Just east of the Pliny ring is a $15-\mathrm{km}$-wide, horseshoeshaped mountain ridge with an interior depression that is $\sim 700 \mathrm{~m}$ lower than the surrounding ridge (Fig. 25). We have 

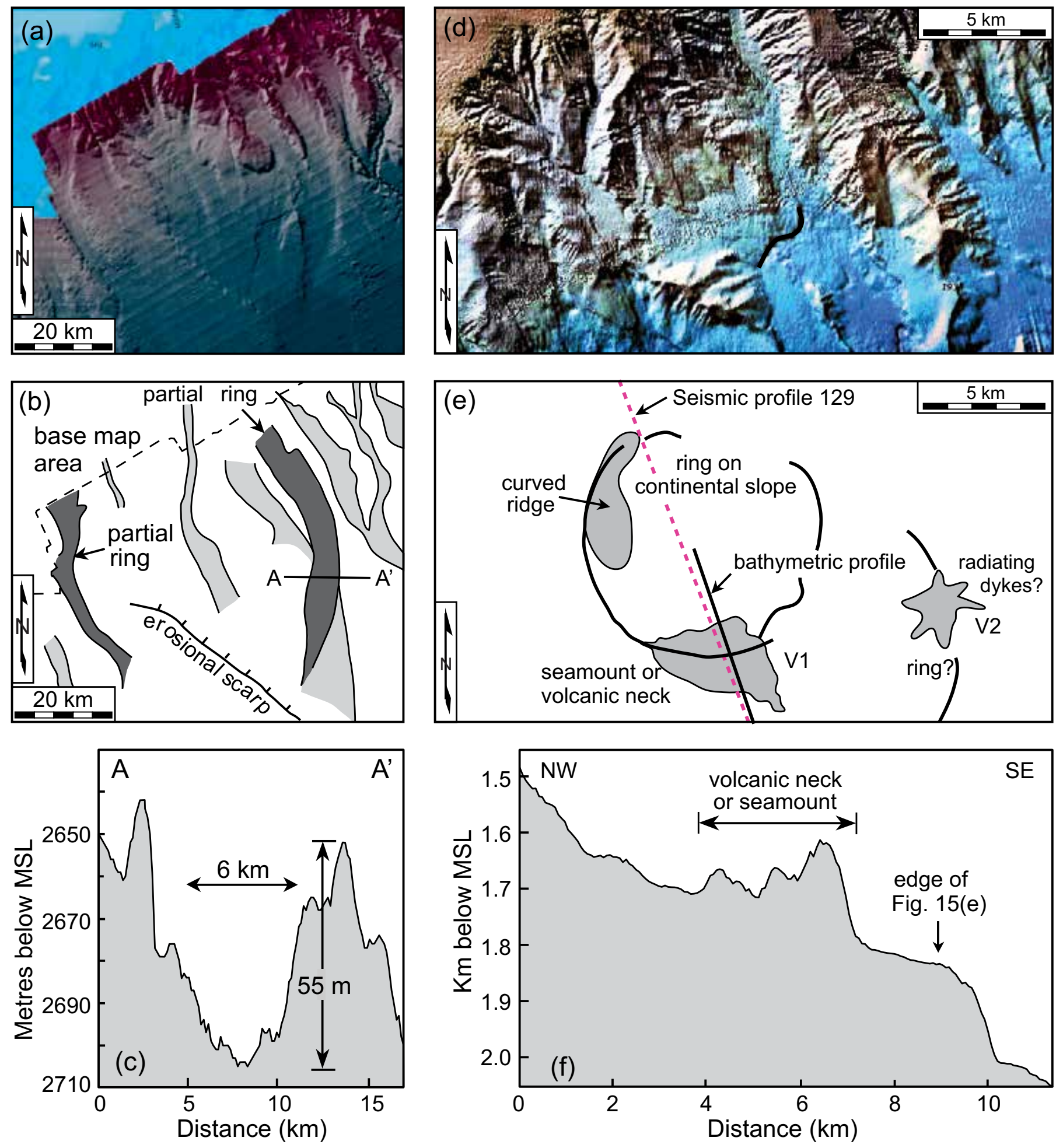

Figure 15. (above and next page) Selected sonar images of partial rings and interpreted seamounts along the continental margin (see Fig. 3 for locations). (a) IHS-enhanced MBES image of a $\sim 50-\mathrm{km}$-diameter partial ring formed by two unnamed arc-shaped canyons west of Bear Seamount (dark grey patterns in (b)). Colors represent varying water depths ranging from blue for the greatest water depths, to green for intermediate depths, to red for the shallowest depths. The NE-SW-trending stripes are artifacts of sonar acquisition and processing. (b) Interpreted drawing of (a). (c) Bathymetric profile across the curved canyon that defines the east side of the ring $(\mathrm{VE}=159)$. Lighter grey patterns are other canyons. (d) IHS-enhanced MBES image that shows an arc-shaped feature and two interpreted small seamounts (V1 and V2) on the continental slope northwest of Bear Seamount. Colors represent water depths ranging from blue for the greatest depths to brown for the shallowest water depths. (e) Line drawing of (d). (f) Bathymetric profile across (caption continues next page) 

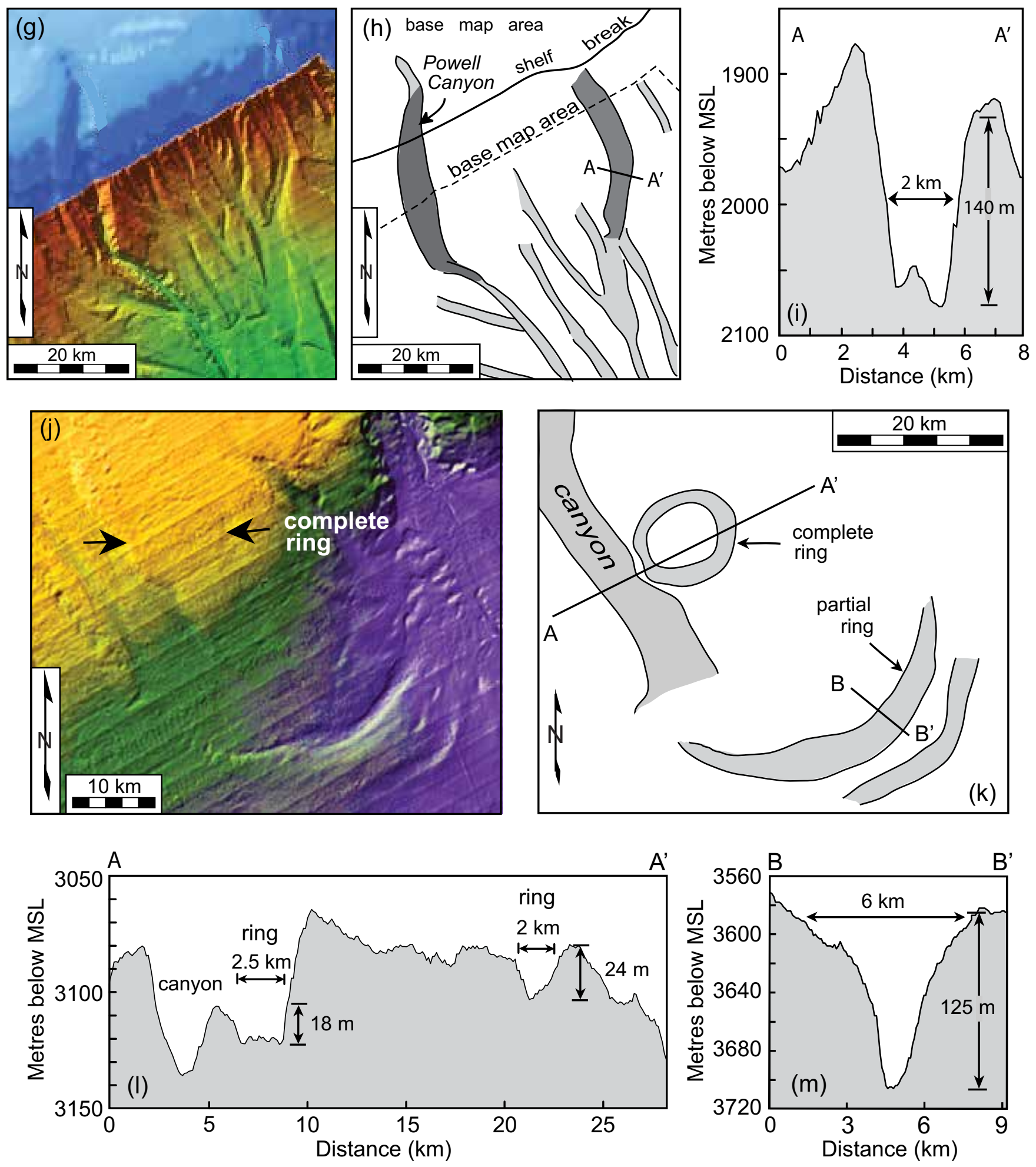

the interpreted seamount labeled V1 in (e). (g) Examples of curved submarine canyons on the continental slope north of Bear Seamount (dark grey patterns) formed by Powell canyon and an unnamed, arc-shaped canyon to the east. (h) Line drawing of (g). (i) Bathymetric profile A- $A^{\prime}$ across the easternmost curved canyon (VE $\left.=26\right)$. (j) IHS-enhanced sonar image that shows a submerged, 30-km-long, curved depression southwest of Bear Seamount and a subtle closed, 10-km-diameter ring (between opposing arrows) to the northwest. Colors represent water depths ranging from purple for the greatest water depths to yellow for the shallowest depths. (k) Interpreted drawing of (j). (l) Bathymetric profile across the smaller complete ring in $(\mathrm{j})(\mathrm{VE}=12)$. $(\mathrm{m})$ Bathymetric profile across the larger curved depression in the southeastern part of $(\mathrm{j})$ $(\mathrm{VE}=57)$. The images in $(\mathrm{a}),(\mathrm{d}),(\mathrm{g})$ and $(\mathrm{j})$ were taken from UNH/CCOM-JHC (2015b). 


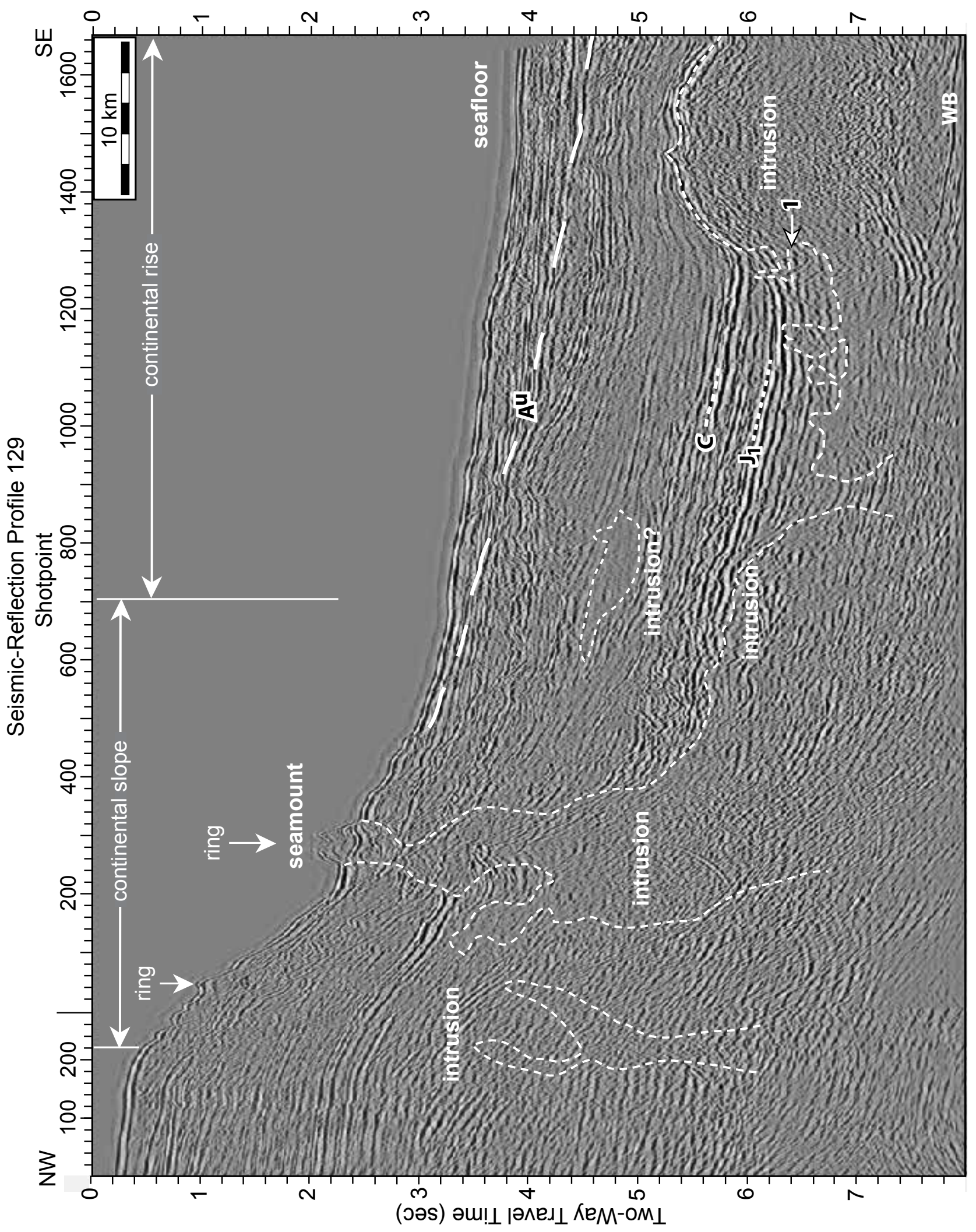

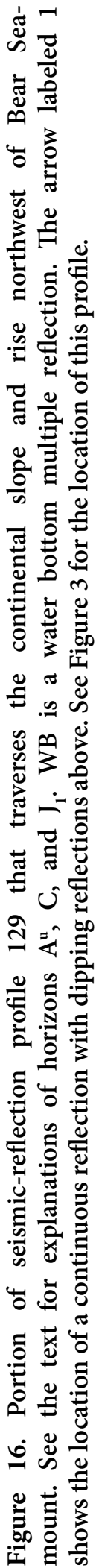

named this valley the Success Hill depression. The curved mountain range and Success Hill depression terminate against the Pliny ring to the west (Fig. 25) and crosscut various units of the generally NE-SW-trending, Silurian and Devonian metasedimentary and metavolcanic rocks of the Central Maine belt (Lyons et al. 1997).
A $28-\mathrm{km}$-diameter, ring-shaped morphological feature, herein named Nulhegan ring, is located northwest of the Pliny ring (Fig. 26). The Nulhegan ring is formed mainly by curved segments of the Connecticut and Pherrins river valleys and the southwest rim of the Nulhegan basin. Several morphological features coincide with or occur within the 

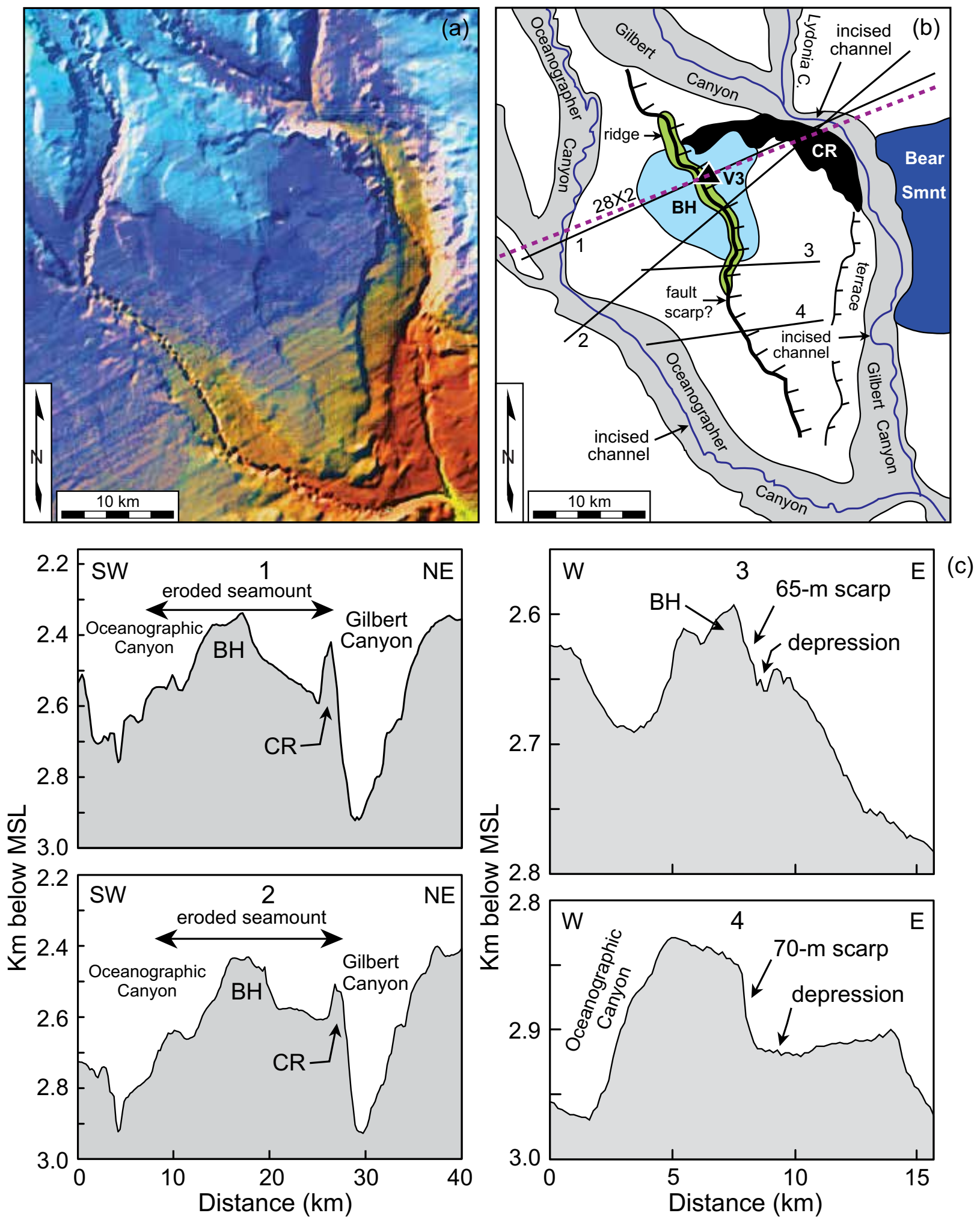

Figure 17. (a) IHS-enhanced MBES image of the interpreted, heavily eroded seamount between the Oceanographer and Gilbert canyons. Colors represent water depths that range from reddish brown for the deepest water depths to light blue for the shallowest areas along the upper continental rise. See Figure 3 for the location of this image. (b) Interpreted drawing of (a). The thin black lines are the locations of the bathymetric profiles in (c). The dashed line is seismic-reflection profile 28X2. The solid triangle labeled V3 is the location of the small ( 1-km-wide) seamount or dike interpreted from Figure 18. (c) Bathymetric profiles across the heavily eroded seamount. $\mathrm{VE}=417$ for profiles 1 and 2, 622 for profiles 3 and 4 and 352 for profile $5 . \mathrm{BH}$ is the bathymetrically high area surrounding the interpreted small seamount or dike (V3) and CR is the curved ridge along the southwest side of Gilbert Canyon. 
Seismic-Reflection Profile 28X2

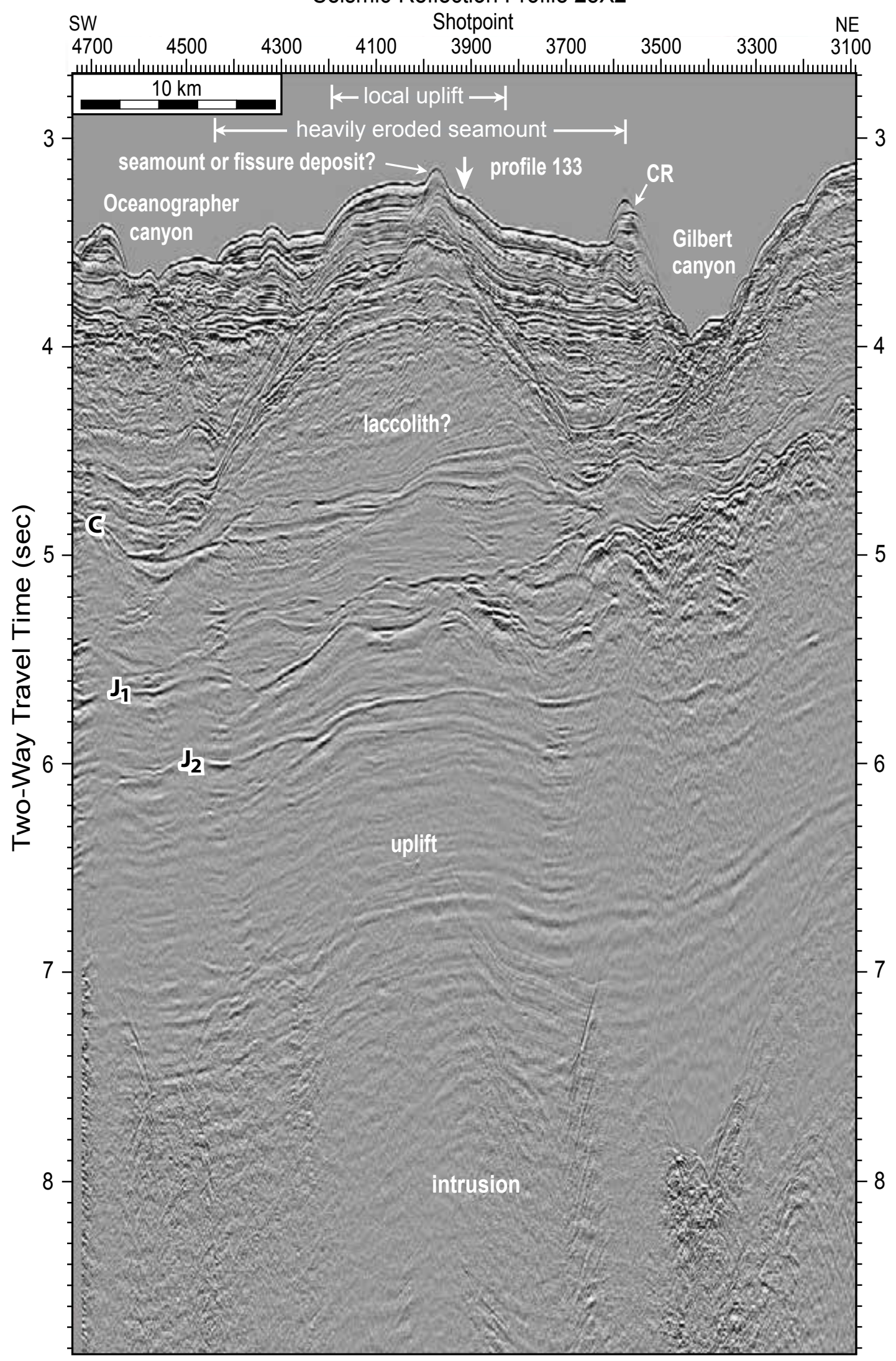

Figure 18. Portion of seismic-reflection profile 28X2 that traverses the interpreted heavily eroded seamount in Figure 17. $\mathrm{CR}$ is the curved ridge shown in Figure 17b. See Figure 17b for the location of this profile. This profile was modified from Triezenberg et al. (2016). See the text for descriptions of horizons $\mathrm{C}, \mathrm{J}_{1}$, and $\mathrm{J}_{2}$. 

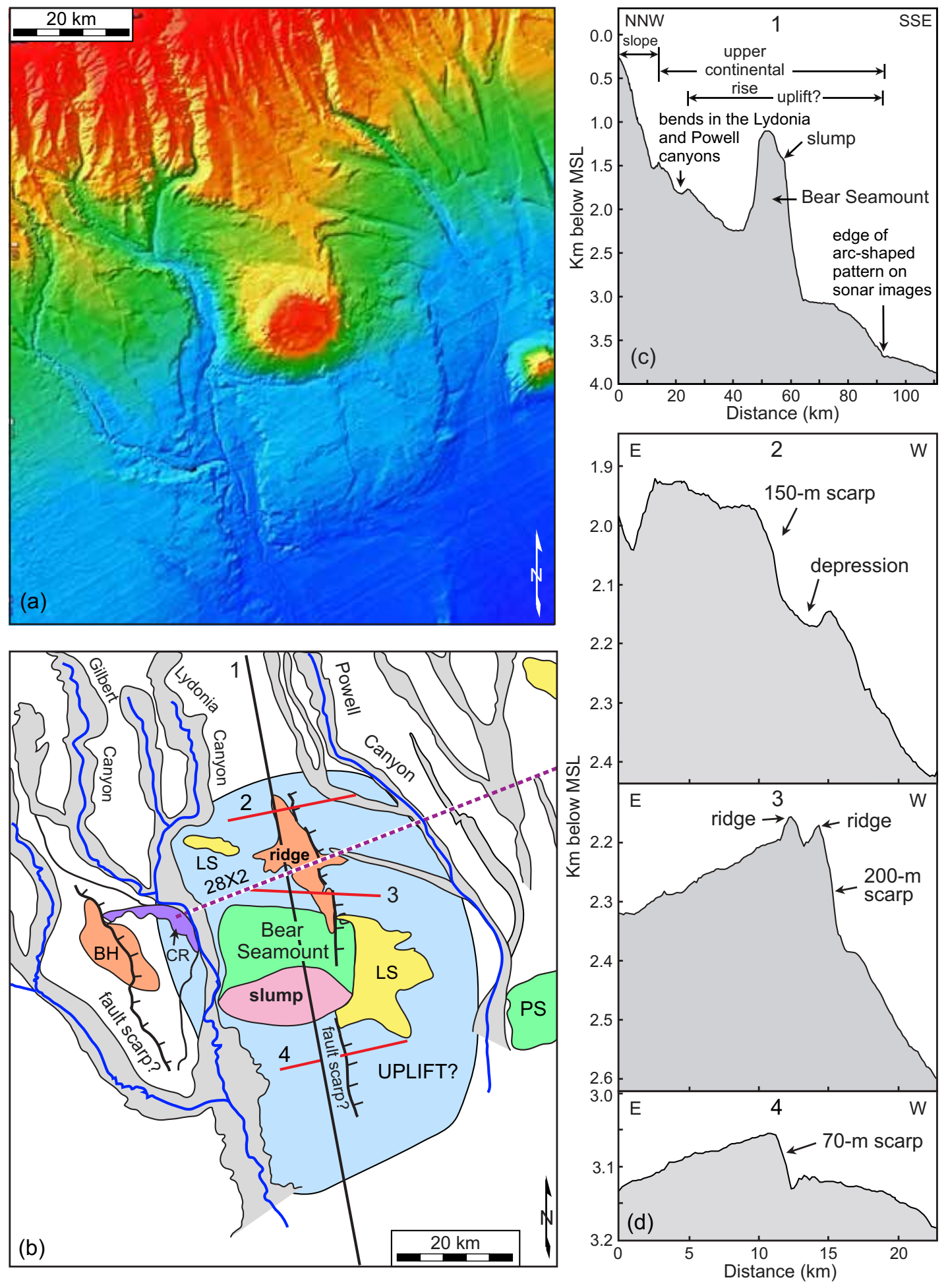

Figure 19. (a) IHS-enhanced MBES image of Bear Seamount and the surrounding area. The colors represent varying water depths ranging from dark blue for the greatest water depths, to green for intermediate depths, and then red for the shallowest depths. See Figure 3 for the location of this area. (b) Interpreted drawing of (a). Ticks are on the downthrown side of the interpreted east-facing scarp. Solid lines labeled 1-4 are bathymetric profiles shown in (c) and (d). The pink pattern labeled $\mathrm{BH}$ is an elevated area on the seafloor west of Bear Seamount and the purple pattern labeled CR is a curved ridge along the southwest side of Gilbert Canyon. The yellow patterns labeled LS are interpreted landslides. The light green pattern labeled PS is the Physalia Seamount. The large light purple pattern surrounding Bear Seamount is a bathymetrically higher area described in the text. The location of seismic-reflection profile 28X2 is shown as a dashed line. (c) Bathymetric profile 1 across Bear Seamount. (d) Bathymetric profiles 2-4 constructed across the NNW-SSE-oriented ridge north of Bear Seamount and scarp to the south. 


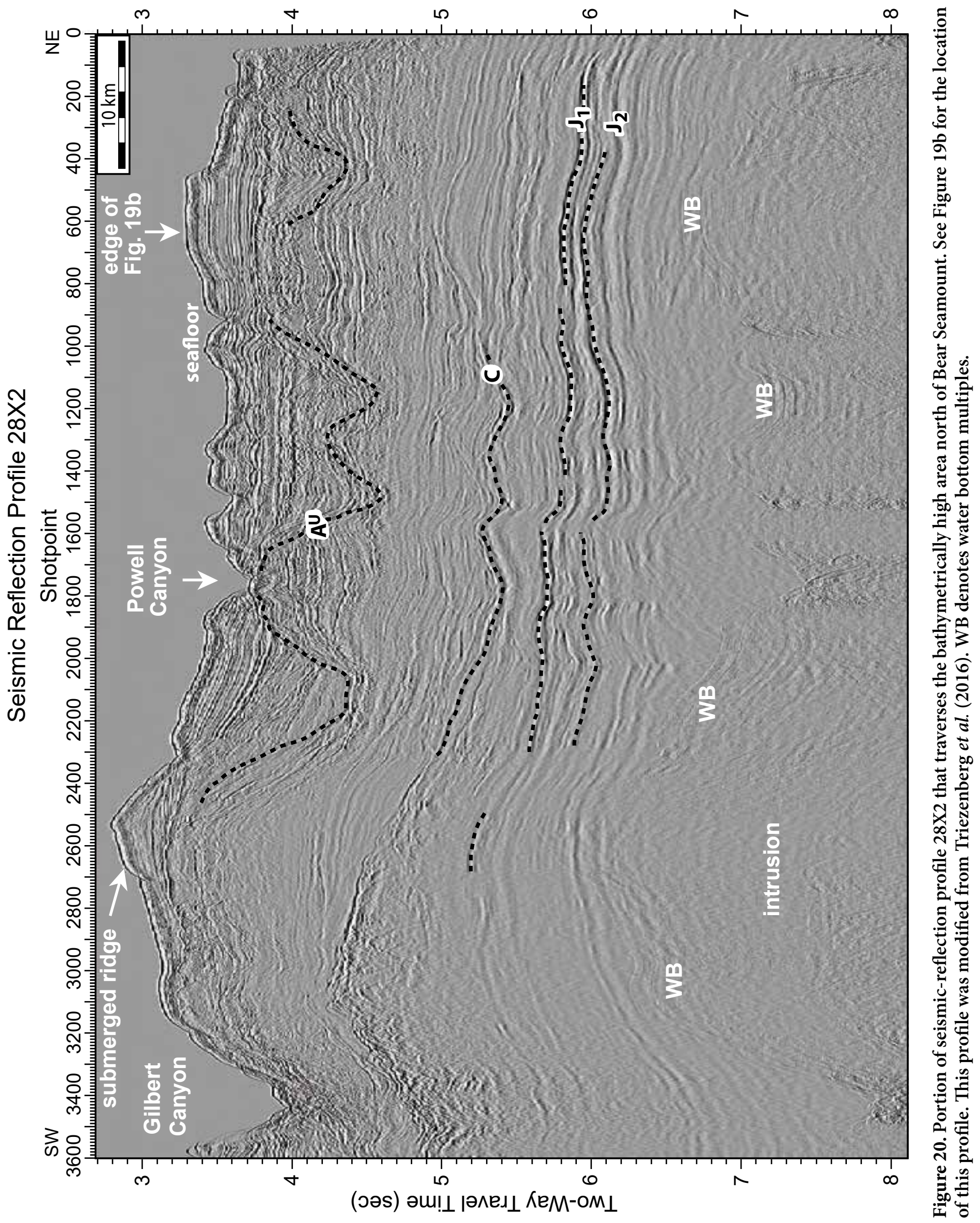



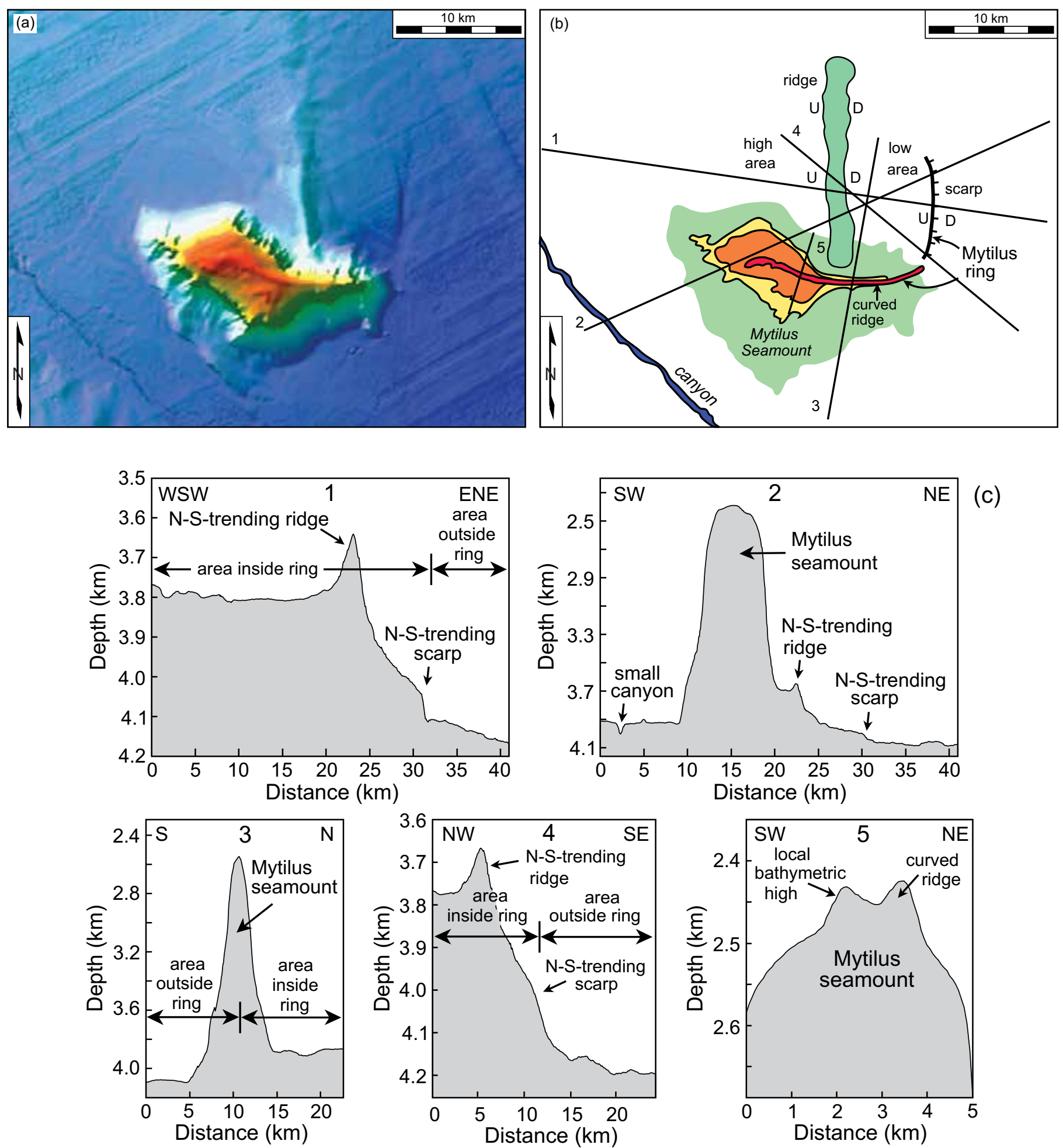

Figure 21. (a) MBES image of Mytilus Seamount. See Figure 3 for the location of this area. (b) Interpreted drawing of (a). Ticks are on the relative down side of the scarp. Symbols $U$ and D represent the relative up and down sides across the scarp and the N-S-oriented ridge. Solid lines labeled 1-5 are bathymetric profiles shown in (c). (c) Bathymetric profiles constructed across the Mytilus Seamount, east-facing scarp, and N-S-oriented ridge.

interior of Nulhegan ring, including the 14-km-diameter Nulhegan topographic basin to the southwest and a 4 -km-diameter curved ridge inside its northeast rim (Fig. 26). The curved ridge to the northeast occurs at the apex of a small, unnamed mountain. On its northeastern flank, this mountain displays a pattern of features that resembles flatirons (Fig. 26e).

Immediately northwest of the Nulhegan ring is a 

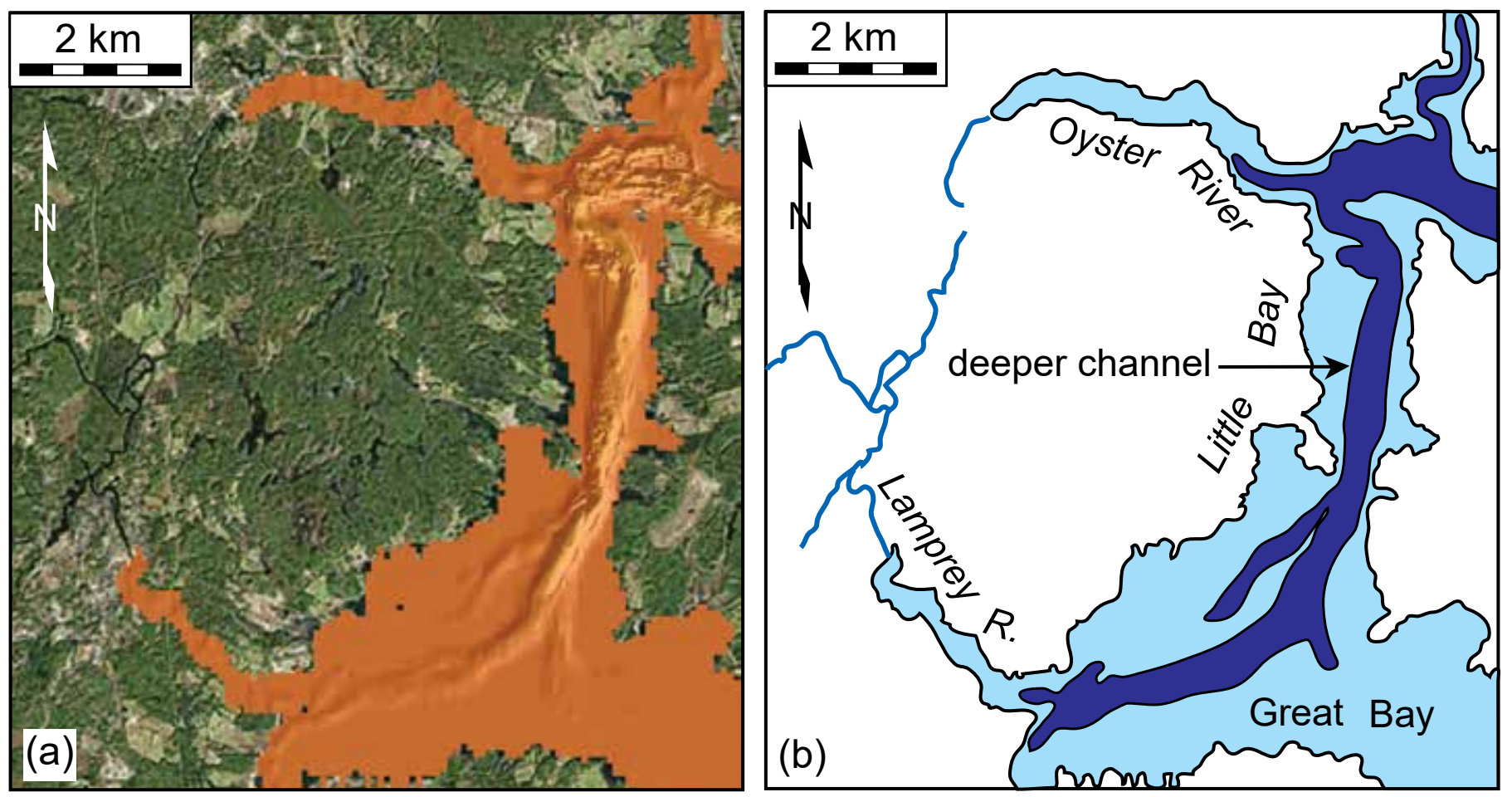

Figure 22. (a) Sonar image of the Great Bay ring in southeastern New Hampshire. See site B in Figure 2 for the location of this partial ring. (b) Interpreted drawing of (a).

40-km-diameter, ring-shaped depression in northeastern Vermont and southern Quebec that we have named the Memphrémagog ring (Fig. 27). It is formed mainly by Lake Memphrémagog to the west and the curved Coaticook River to the east. The Magog River valley defines part of the northern rim of this large ring (Fig. 27). The location of the southern rim of the Memphrémagog ring is uncertain because several ring-shaped features occur in that area (Fig. 27).

The most prominent of the ring-shaped morphological features along the southern half of the Memphrémagog ring is a $10-\mathrm{km}$-long, $1.5-$ to $2-\mathrm{km}$-wide, NNW-SSE-oriented, elliptical-shaped depression in northeastern Vermont that we have named Derby ring (Fig. 28). The terrain along the south side of this ring is elevated above the surrounding area (Fig. 28c, profile 1). A smaller, 4-km-diameter partial ring (Clyde ring) intersects the southeastern rim of Derby ring (Figs. 28a and 28b).

Fifteen $\mathrm{km}$ northwest of the Memphrémagog ring, a 15-km-diameter, $\sim 1-\mathrm{km}$-wide, ring-shaped depression surrounds the $5-\mathrm{km}$-diameter Shefford igneous intrusion at the southeastern end of the MHIP in southern Quebec (Fig. 29). This ring-shaped depression, which we have named the Shefford ring, is defined mainly by curved stream valleys (Fig. 29).

\section{DISCUSSION}

\section{Origin of the ring-shaped features and small round hills beneath the Gulf of Maine and along the continental margin}

Various mechanisms can produce ring-shaped structures, including salt diapirs, some glacial processes, meteorite impacts, and igneous intrusions (e.g., Eppelbaum 2007). Salt diapirs are not a likely cause of the ring-shaped features between coastal New Hampshire and the NES because the only area along the trend of the ring-shaped features where salt diapirs could exist is along the outer edge of the continental shelf and along the continental margin where the sediments are relatively thick and layers of salt exist at depth (Schlee and Klitgord 1988). Furthermore, although layers of salt occur beneath Georges Bank Basin, salt diapirs are not common near the southern part of the basin where it coincides with the trend of the rings (Schlee and Klitgord 1988). Nor do any of the seismic-reflection profiles that traverse this part of the continental margin (Triezenberg et al. 2016) show evidence for salt diapirs, such as rim synclines caused by slumping of nearby formations or collapse structures from the removal of salt at depth (e.g., Figs. 16 and 20).

The ring-shaped features also do not appear to be associated with glacial processes. Glacial abrasion, for example, favors the formation of linear morphological features, not ring-shaped features. Nor are the rings likely the result of 

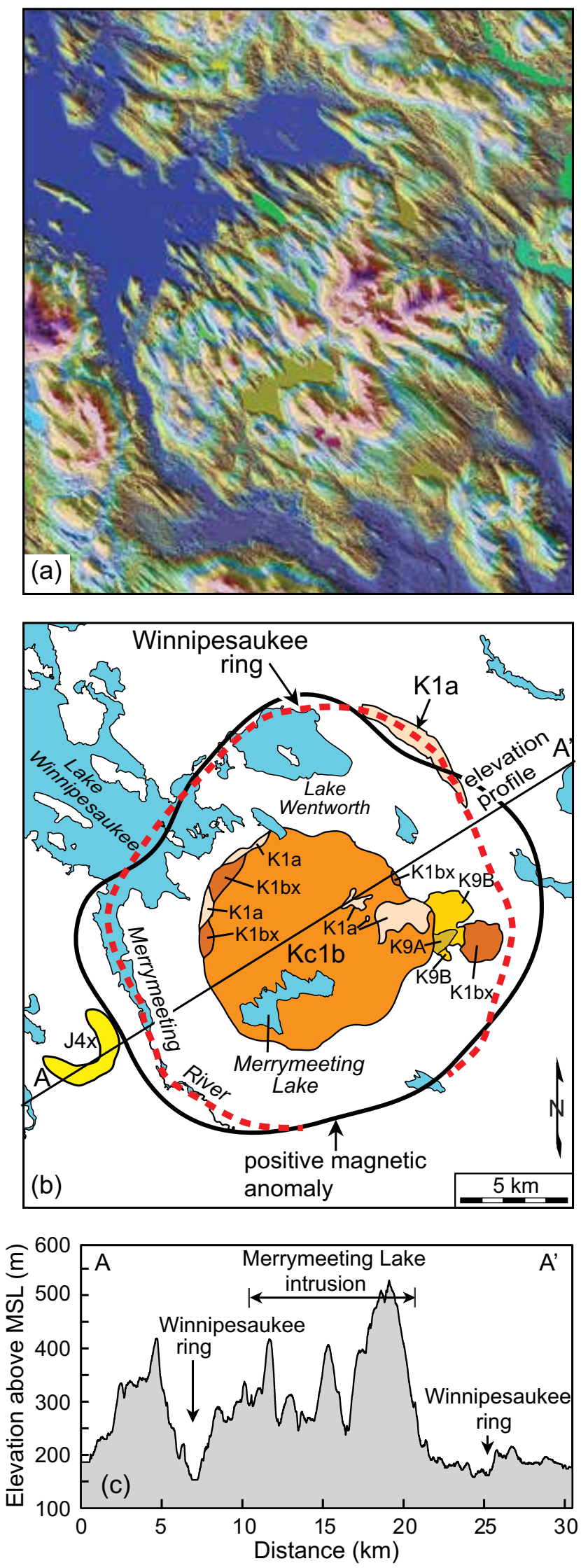

Figure 23. (a) IHS-enhanced LiDAR image of the Winnipesaukee ring that surrounds the Merrymeeting Lake igneous intrusion. The colors range from blue for the lowest elevations, to green for intermediate elevations, to purple for the highest elevations. See Figure 5 for the location of this area. (b) Interpreted drawing of (a). The black contour is an interpreted positive magnetic anomaly from Figure 31. The following Cretaceous bedrock map units of the Merrymeeting Lake intrusion are from Lyons et al. (1997): Kclb - mesoperthitic biotite granite, K1bx - porphyritic biotite granite, K1a - rhyolite and fine-grained granite, K9A - hornblende diorite, and K9B - augite-hornlendebiotite gabbro. Bedrock unit $\mathrm{J} 4 \mathrm{x}$ is a Jurassic ring dike consisting of quartz syenite (Lyons et al. 1997). (c) Elevation profile A- $A^{\prime}$ constructed across the Merrymeeting Lake intrusion and the Winnipesaukee ring.

glacial-related collapse structures, such as large kettle holes, because of their large size, which favors their interpretation as bedrock features. Some of the ring-shaped depressions are several kilometres in diameter, several hundred metres wide, and tens of metres deep, whereas sediments in the western Gulf of Maine are no more than a few tens of metres thick, except beneath the banks and ledges where they may be 200 to $300 \mathrm{~m}$ thick (Oldale 1994). For example, the curved depression associated with the northeastern rim of the $30-\mathrm{km}$-diameter Tillies outer ring is $3 \mathrm{~km}$ wide and $45 \mathrm{~m}$ deep (Fig. 10c), whereas the sediments in this area are no more than a few tens of metres thick (Uchupi and Bolmer 2008). Glacial plucking and subaerial erosion may, however, have preferentially eroded away fractured bedrock along ring fractures to produce the arc-shaped depressions. Sedimentation since submergence of the continental shelf and the Gulf of Maine has draped relatively thin layers of sediments over these ring-shaped ridges and depressions in the bedrock. Furthermore, glacial sediments have also likely prevented the mapping of some small ring dikes both offshore and onshore. For example, surficial geologic maps of northeastern Massachusetts (Stone et al. 2006) show that the arc-shaped ridge in Figure 13d is covered by glacial and marine regressive sediments that have prevented the identification of potential underlying ring dikes.

We also ruled out meteorite impacts as a likely cause of the rings because the long axes of the elliptical-shaped rings in the study area are oriented in various directions (Figs. 8a, $13 \mathrm{a}$, and 14a). Furthermore, the long axes of most of the elliptical rings are tranverse to the NNW-SSE trend formed by the ring-shaped features between southern Quebec and the NES. Thus, it is unlikely that the various ring-shaped features are from meteorite impacts.

Thus it is more likely that the various rings offshore are related to igneous intrusions. The strongest evidence for an igneous origin are the ring-shaped depressions that surround the mapped igneous intrusions onshore, such as the Pawtuckaway, Winnipesaukee, Pliny, and Shefford rings (Figs. 6a, 23, 24, and 29). Furthermore, the coincidence of 

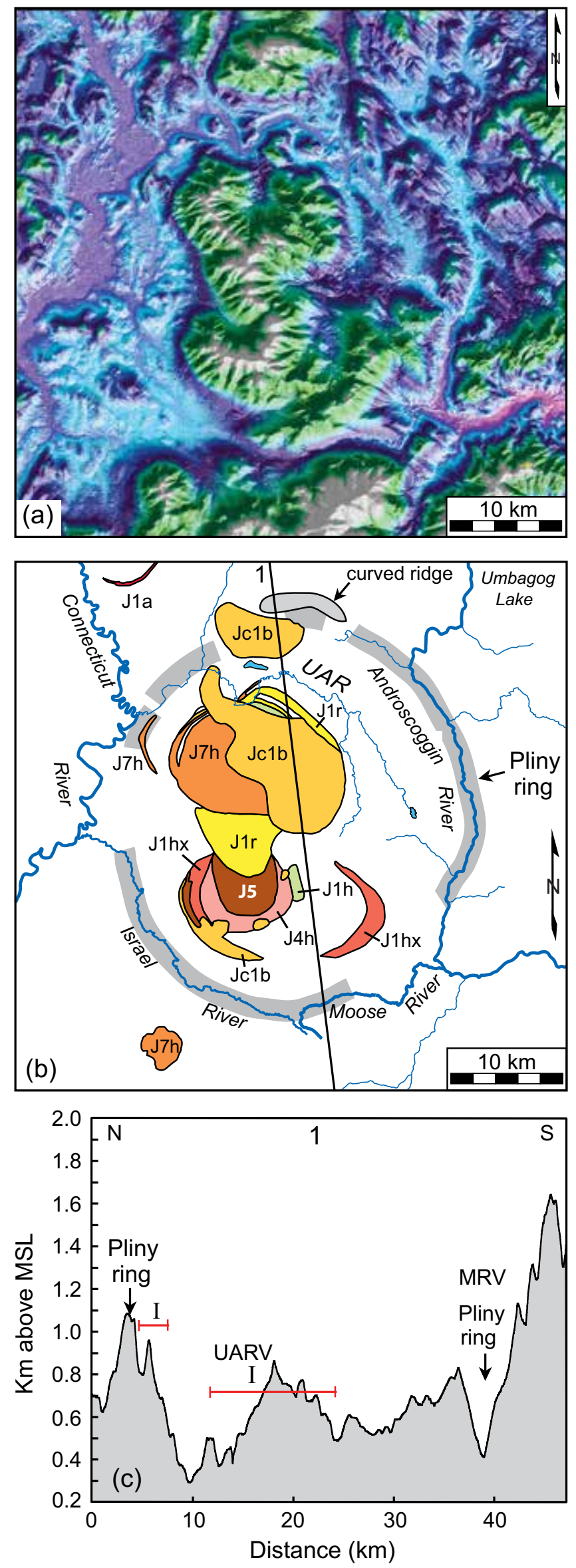

Figure 24. (a) IHS-enhanced DEM image of the Pliny and Percy ring dike complexes in the WMMS. The colors range from purple and light blue for the lowest elevations, to green for intermediate elevations, to off-white for the highest elevations. See Figure 5 for the location of this area. (b) Interpreted drawing of (a). UAR is the Upper Ammonoosuc River. Jurassic geologic units shown are: Jc1b - Conway granite, J1a - fine-grained granite, J1r mesoperthitic granite, J1h - Hastingsite granite, J1hx granite porphyry, J4h - hornblende or alkali amphibole quartz syenite, J5 - hornblende-biotite quartz monzodiorite, J7h - hornblende syenite (Lyons et al. 1997). Solid line labeled 1 is the elevation profile shown in (c). (c) Elevation profile constructed across the Pliny ring. MRV - Moose River valley, UARV - Upper Ammonoosuc River valley. Horizontal lines labeled I are the locations of mapped igneous intrusions.

likely seamounts and mapped igneous intrusions with some of the ring-shaped depressions strongly suggests that they erupted upward along ring fractures from magmas at depth. For example, the curved Mytilus Seamount near the northwestern end of the New England seamount chain erupted along an arc-shaped ring (Fig. 21). Another example of a seamount that coincides with a ring-shaped feature is the small seamount on the continental slope that coincides with a 10-km-size, arc-shaped ring (Figs. 15d, site V1, and 16). An example of an igneous intrusion that coincides with a ring-shaped feature onshore is the curved igneous intrusion along the northern side of the Winnipesaukee ring in southeastern New Hampshire (unit K1a, Fig. 23b).

Based on these observations, it is more likely that the rings are either ring dikes composed of igneous rock that is more erodible than the surrounding country rocks or they are ring fractures associated with igneous intrusions at depth. For example, the diorite ring dikes of the Pawtuckaway ring dike complex form low lands whereas the more felsic monzonite ring dikes form arc-shaped ridges (Fig. 6d).

The small round, flat-topped hills in the western Gulf of Maine, such as Boston roundtop and Newbury hill (Figs. 8a and 11d), also appear to be igneous bedrock features. Their circular shapes and flat tops resemble those of the Monteregian Hills in southern Quebec (Fig. 6e). Also, although their composition is not known, the resistance of the small round hills to glacial abrasion by the Pleistocene ice sheets suggests that they are composed of tough, erosionally resistant lithologies, such as most igneous rocks. Lastly, the location of the $2.5-\mathrm{km}$-wide Newbury hill between the two inward-facing scarps in the Scantum Basin (Fig. 8b) suggests that it is associated with an ancient, $18-\mathrm{km}$-wide caldera structure. The curved Cashes scarp and depression that surround the positive Cashes magnetic and gravity anomalies east of Cape Ann (Fig. 12) may also be the remants of an ancient caldera (see next section for more details).

Petras star (Fig. 9a) is interpreted to be a volcanic neck because its radiating ridges resemble those of known volcanic 

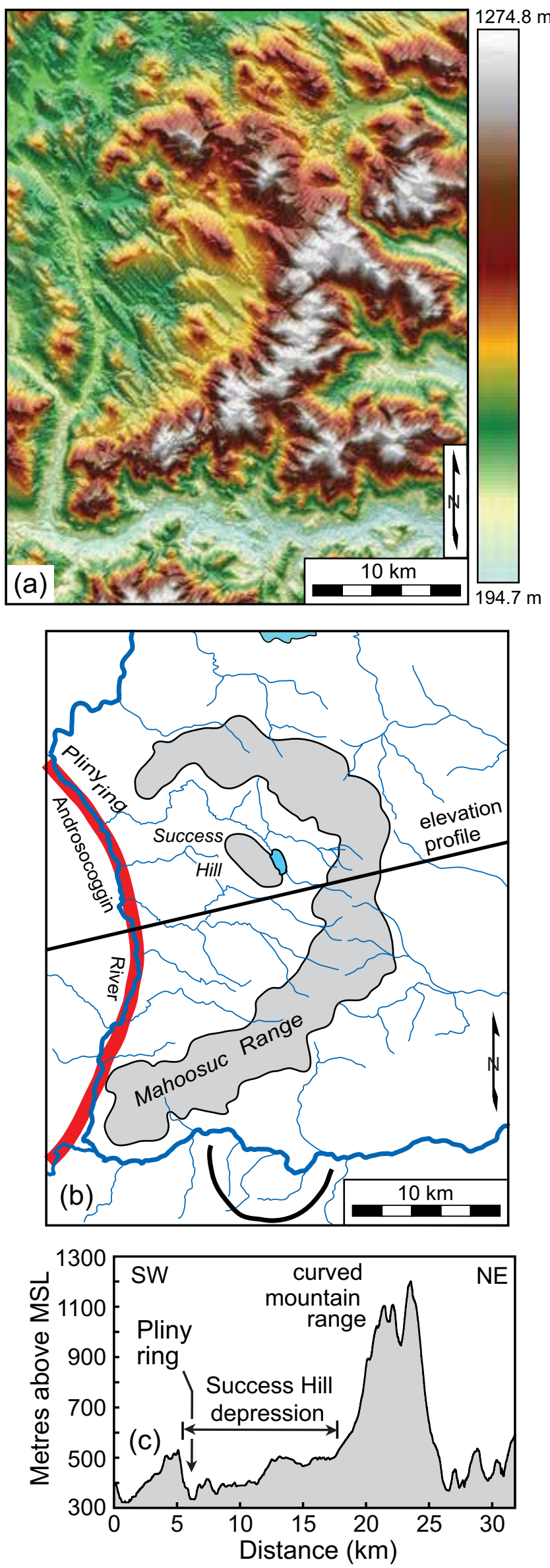

Figure 25. (a) DEM image of the Success Hill depression in northern New Hampshire. See Figure 5 for the location of this image. (b) Interpreted drawing of (a). The large grey pattern is the curved mountain ridge surrounding the Success Hill depression. The thick red contour is Pliny ring. The line traversing the diagram is the elevation profile shown in (c). (c) Elevation profile across the Success Hill depression.

necks with radiating dikes, such as Ship Rock in New Mexico and some of the New England seamounts (Fig. 9d). The resistance of Petras star to glacial abrasion during Pleistocene time also suggests that it is composed of a tough rock type, such as igneous rock, that could have survived the Pleistocene glaciations.

\section{Interpretation of aeromagnetic and gravity data in the study area}

The gravity and aeromagnetic anomaly maps shown in Figures 30-32 revealed anomalies that support the existence of igneous intrusions in a few areas along the NEHT. For example, the alignment of the large, 50- to $100-\mathrm{km}$-long, positive magnetic anomalies on the continental shelf with the NES to the southeast (Fig. 30) suggests that they are associated with igneous intrusions beneath the shelf sediments. Schlee and Klitgord (1988) postulated that these anomalies are associated with buried Cretaceous intrusions that are related to the same mechanism that produced the NES.

Another large magnetic anomaly that may be associated with a mafic intrusion at depth is the large positive magnetic anomaly near Cashes Ledge, herein named the Cashes magnetic anomaly (Figs. 12 and 31). Although samples of bedrock taken from Cashes Ledge are Early to Middle Devonian granitic and volcanic rocks (Barr et al. 2011), the positive Cashes magnetic anomaly and the positive gravity anomaly that coincides with the magnetic anomaly (Fig. 12) suggest that a large mafic intrusion may occur at depth. If so, then the curved Cashes scarp and depression southeast of the magnetic anomaly (Fig. 12) could be the eroded remnants of a large caldera associated with the intrusion.

Although the ring-shaped features onshore between Cape Ann and Boston coincide with a large positive gravity and magnetic anomaly in that area, most of the local bedrock consists of granitoid rocks (Zen et al. 1983) that normally do not produce positive magnetic and gravity anomalies. However, these rocks may contain enough mafic minerals to have produced the relatively high magnetization in the area. Alternatively, the source of these positive magnetic and gravity anomalies could be from mafic intrusions at depth that are possibly associated with the rings.

Most of the rings offshore do not coincide with positive gravity and magnetic anomalies, and hence may be associated with felsic to intermediate igneous intrusions in the upper crust. Magma differentiation, combined with partial melting of and mixing with more felsic continental crust 

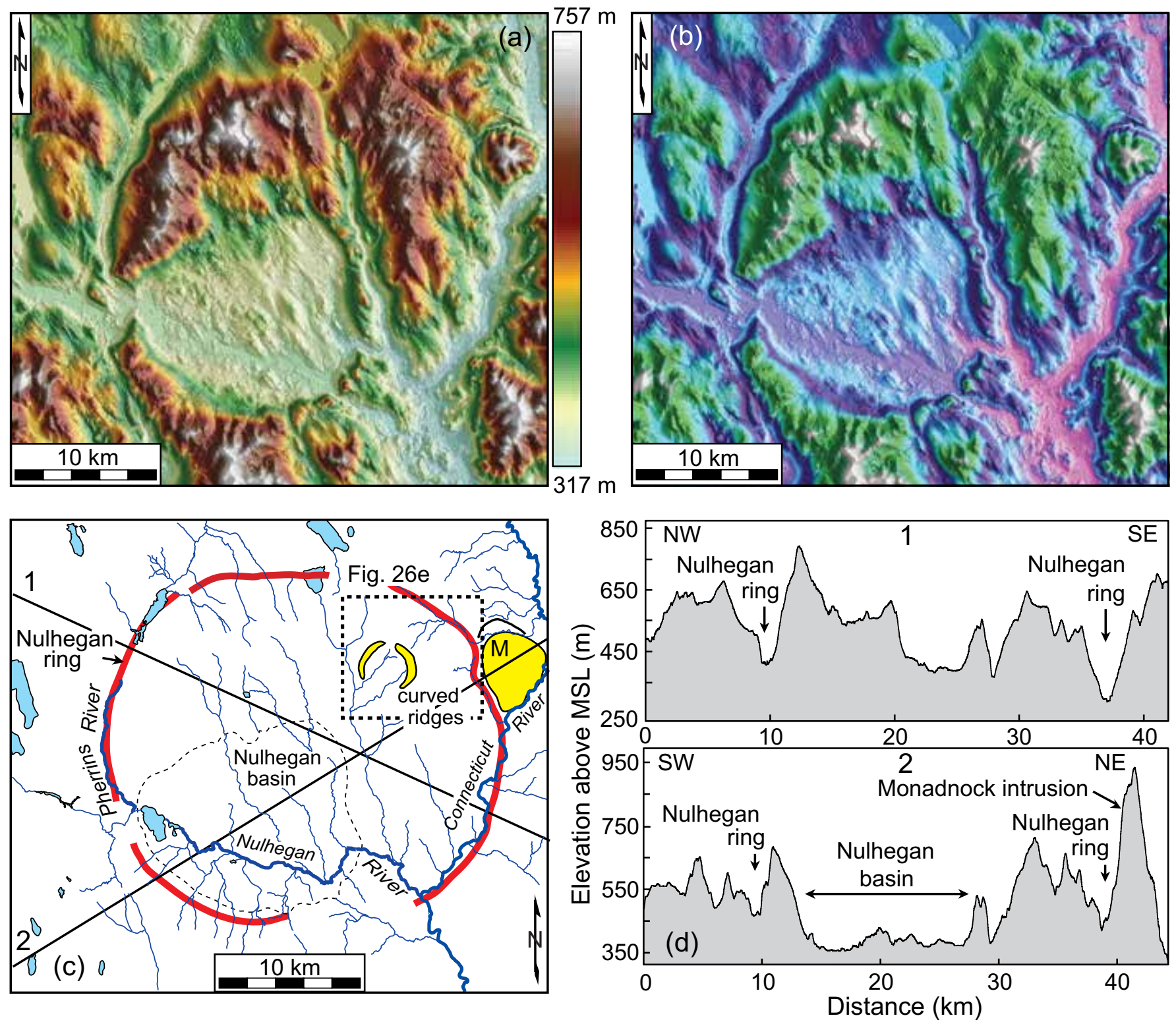

Figure 26. (a) DEM image of the Nulhegan ring and basin in northeastern Vermont. See Figure 5 for the location of this image. (b) IHS-enhanced color version of (a). The colors represent elevations ranging from pink for the lowest elevations, to light blue and green for the intermediate elevations, to white for the highest elevations. (c) Interpreted drawing of (a). The Nulhegan ring is shown by the thick red contour. The dashed contour is the Nulhegan basin. The yellow patterns are the curved ridges near the northeast rim of the Nulhegan ring. The yellow pattern labeled $M$ is the Monadnock intrusion. Solid lines labeled 1 and 2 are the elevation profiles shown in (d). (d) Elevation profiles constructed across the Nulhegan ring. (e) (next page) DEM image in northeastern Vermont that shows a 4-km-diameter pair of curved ridges near the northeast rim of the Nulhegan ring. See (c) for the location of this image. (f) (next page) Interpreted drawing of (e).

as the originally mafic magmas at depth migrated upward, could have made some of the magmas more felsic in composition, thus lowering their magnetic intensities. Birch (1984), for example, noticed that the elliptical-shaped ridge associated with the Hampton Falls ring (Fig. 8a) is characterized by a relatively low magnetic intensity surrounding a positive magnetic anomaly. He postulated that this ridge is a felsic ring dike surrounding a mafic intrusion at depth that is more susceptible to erosion. Our interpretation that many of the ring-shaped features in the western Gulf of Maine are associated with felsic to intermediate igneous intrusions is further supported by the presence of felsic to intermediate ring dike complexes onshore in central New England, such as the Pawtuckaway ring dike complex (e.g., Eby 1995).

The ring-shaped morphological features may also represent the approximate size of the intrusions at depth that produced the rings. This hypothesis is supported by the similarity in size between the positive magnetic anomaly associated with the Merrymeeting Lake intrusion and the Winnipesaukee ring in southeastern New Hampshire (Fig. 23b). If so, 

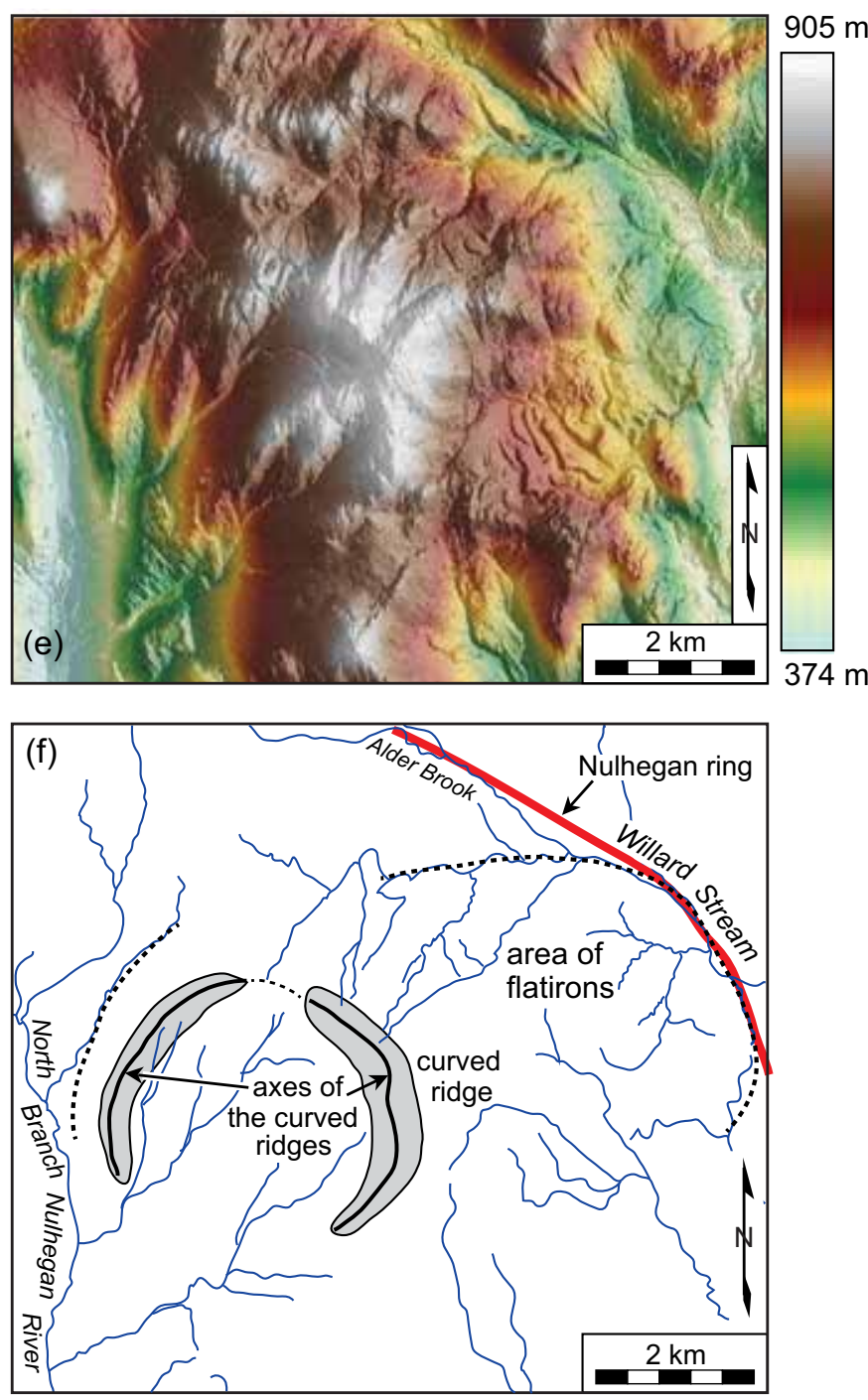

then the intrusions beneath some of the larger rings, such as the Memphrémagog ring (Fig. 27), could be quite large.

We also investigated the gravity lineaments in the western Gulf of Maine (Fig. 32) and the NW-SE-trending Burlington lineament onshore (Figs. 4 and 5) to determine if they could be related to the ring-shaped features between southern Quebec and the continental shelf. The most anomalous characteristic of these lineaments is that they crosscut the NE-SW-trending Paleozoic terranes and Triassic basins (Fig. 4), which suggests that they are associated with basement faults beneath these terranes and basins. The lineaments also crosscut the general NW-SE trend of the ringshaped morphological features between southern Quebec and the continental shelf (Fig. 4). Thus, it is unlikely that the lineaments are associated with the formation of the rings and intrusions as hypothesized by McHone and Shake (1992). It is more likely that basalt magmas from the New England plume ascended upward along some of the basement faults through the lower continental crust as the plume passed beneath these areas, thus producing the linear positive gravity anomalies.
Origin of the curved ridges and topographic depressions in northern New Hampshire and Vermont

Several curved ridges and topographic basins were mapped in northern New England along the general trend of the ring-shaped features (e.g., Figs. 25 and 26). We considered the possibility that glacial and subaerial erosion may have produced some of these curved ridges. However, many of the curved ridges are oriented transverse to the general NE-SW trend of the local bedrock formations and some of them border ring-shaped depressions. Furthermore, their coincidence with the general trend between the MHIP and WMMS (Fig. 5) suggests that they are related to igneous intrusions. Thus, one possible explanation for these curved ridges is that they were caused by uplift from the upward push of intrusions at depth as they ascended through the upper continental crust. Note, for example, the 4-km-long curved ridge at the crest of a mountain near the northeastern rim of the Nulhegan ring in Figure 26e. It is surrounded on its eastern side by flatiron-shaped features that suggest that the rocks beneath this mountain may have been domed up by the upward push of an underlying igneous intrusion. The curved ridge could be either an unmapped ring dike or past deformation from the acending ancient magma below. Another example of interpreted uplift above ancient ascending magmas is the Derby ring. The terrain south of its southern rim increases in elevation as it approaches the ring (Figs. 28a and 28c, profile 1). Ascending magma associated with the intrusion at depth may have domed up the rocks surrounding the Derby ring. Figure 33 is a conceptual diagram demonstrating this style of uplift above some of the interpreted igneous intrusions.

The relatively large topographic basins in northern New England, such as the Nulhegan basin in northeastern Vermont (Fig. 26) and the Success Hill depression in northern New Hampshire (Fig. 25), are also anomalous. One possible origin of these basins is that the bedrock beneath them is more susceptible to erosion than the bedrock in the surrounding areas. The Nulhegan basin, for example, is underlain by granitoid rocks of the Nulhegan pluton while the surrounding area is underlain by metamorphic rocks of the Connecticut Valley Trough (Fig. 5) that contain erosionally resistant quartzite (Ratcliffe et al. 2011). However, the close spatial association of the Nulhegan basin with the Nulhegan ring (Fig. 26) suggests that its formation could also be from an igneous process, such as caldera-related subsidence.

In contrast to the Nulhegan Basin, the Success Hill depression in northern New Hampshire (Fig. 25) cannot be explained easily by differential erosion because it is underlain by various metasedimentary and metavolcanic formations of the Central Maine belt that continue beyond the edge of this depression. Although there are no mapped igneous intrusions in the Success Hill depression, its curved shape, proximity to the Pliny ring, and coincidence with the general trend of ringshaped features (Fig. 5) taken together suggest that its formation may be related to igneous processes, such as subsidence from the emptying of an underlying magma chamber. 

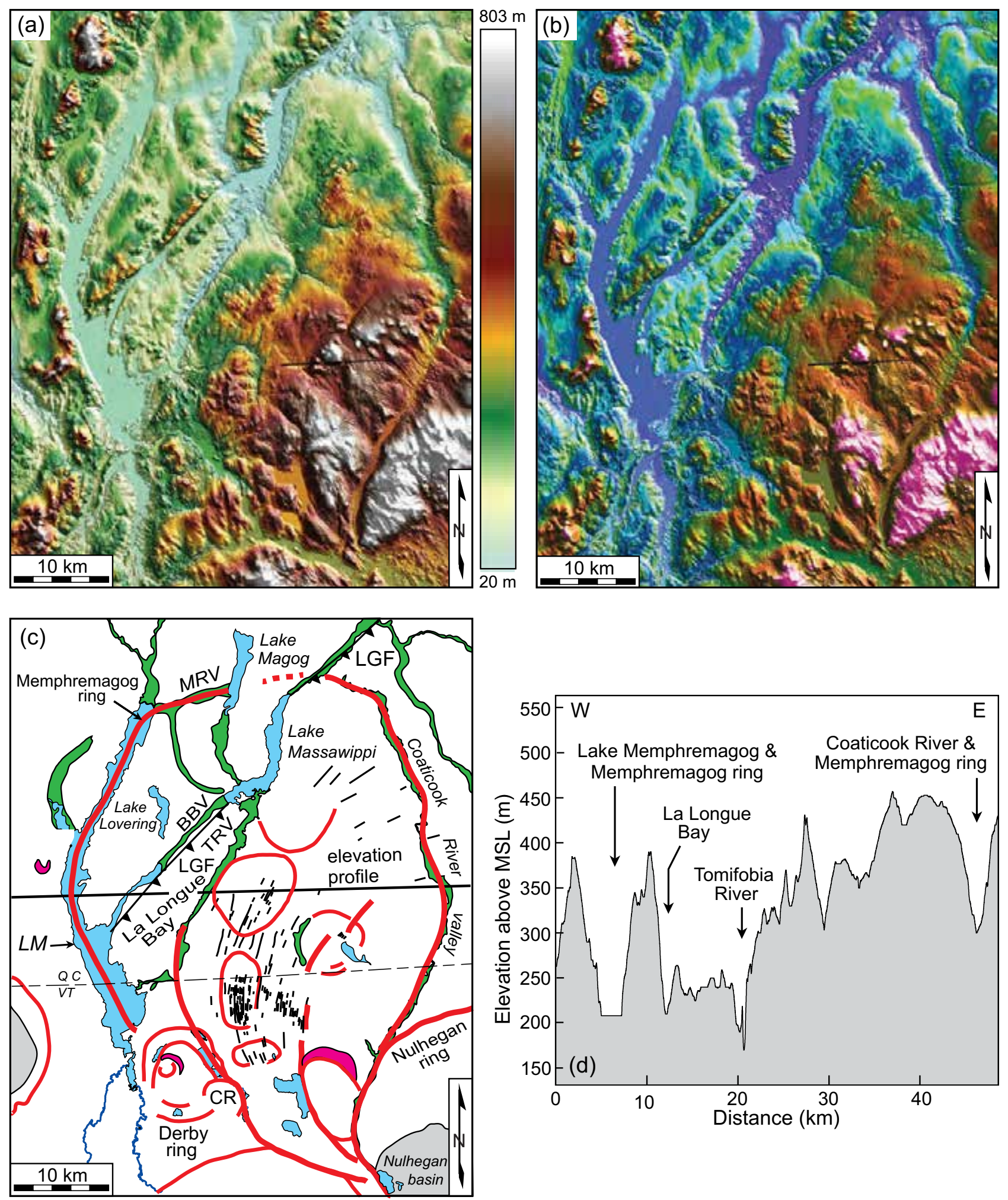

Figure 27. (a) DEM image of the Memphrémagog ring in northeastern Vermont and southern Quebec. See Figure 5 for the location of this image. (b) IHS-enhanced version of (a). The colors represent elevations ranging from blue for the lowest elevations, to green and brown for the intermediate elevations, to pink for the highest elevations. (c) Interpreted drawing of (a). The thick red contour is the Memphrémagog ring. BBV and TRV are the Bunker Brook and Tomifobia River valleys. LGF is the La Guadeloupe Fault (teeth on the upthrown side) of Tremblay and Pinet (2016). CR is the Clyde ring. The E-W-trending solid line is the elevation profile shown in (d). The red contours are interpreted partial rings and the two red patterns are curved ridges. (d) Elevation profile constructed across the Memphrémagog ring. 

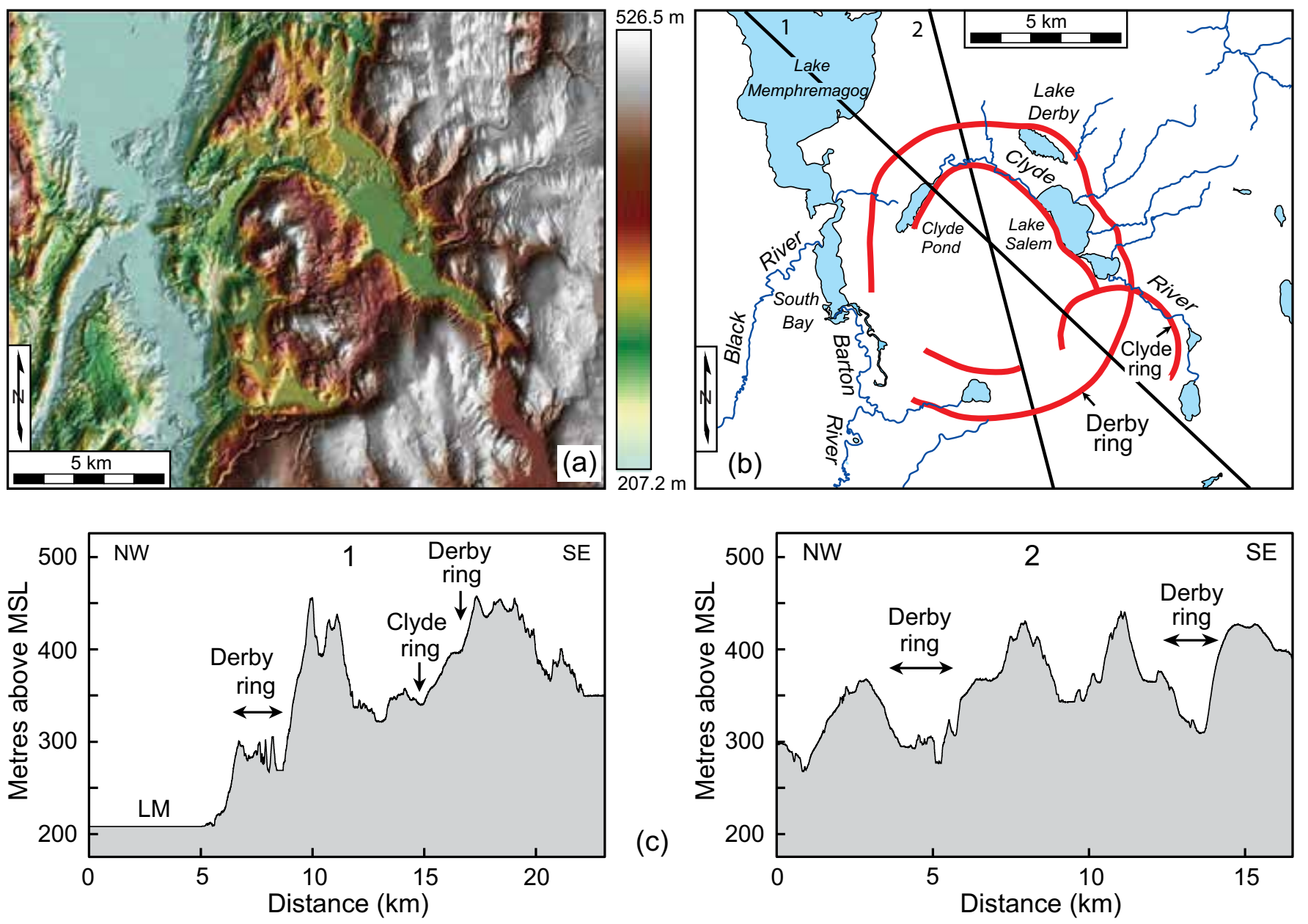

Figure 28. (a) DEM image of the Derby and Clyde rings in northeastern Vermont. See Figure 5 for the location of this image. (b) Interpreted drawing of (a). The Derby and Clyde rings are shown by thick red contours. Black lines labeled 1 and 2 are the elevation profiles shown in (c). (c) Elevation profiles across the Derby and Clyde rings. LM is Lake Memphrémagog.

\section{Uplift and fracturing of the overlying strata by igneous intrusions beneath the continental rise}

Various observations on the continental rise suggest that the upward push of some intrusions may have uplifted and faulted overlying strata. For example, the west-side-up displacement of the seafloor across the east-facing scarp along the eastern side of the Mytilus ring (Fig. 21c, profiles 1 and 4) suggests that the seafloor inside the ring has been displaced upward relative to the seafloor outside it. Likewise, the seafloor inside the Mytilus ring is $\sim 200 \mathrm{~m}$ higher than that to the south (Fig. 21c, profile 3). This interpreted uplift appears to have fractured and displaced the overlying strata inside the Mytilus ring as much as $80 \mathrm{~m}$ along the north-southtrending ridge (Fig. 21c, profile 1). The ridge along the interpreted west-side-up fault may be a dike that intruded along the fault.

The $60-\mathrm{km}$-long, 50-km-wide, bathymetrically high area surrounding Bear Seamount (Fig. 19) also may have formed by uplift that was caused by the upward push of ancient ascending magmas associated with a large buried igneous intrusion beneath this area. The northern flank of this possible intrusion is shown on the E-W-trending seismic-reflection profile 28X2 in Figure 20. The area of interpreted uplift, like that inside the Mytilus ring, is also bisected by a NNWSSE-trending, 60-km-long scarp (Fig. 19) that we interpret to be a fault scarp produced by the upward push of acending magmas. Like the ridge inside the Mytilus ring, the ridge along the scarp north of Bear Seamount may be a dike that formed by a past eruption along the proposed fault. The coincidence of Bear Seamount with the scarp suggests that it erupted upward along the fault.

The curved ridge (denoted CR in Figs. 17b and 18) along the southwest side of Gilbert Canyon suggests that the area between the curved segments of the Oceanographer and Gilbert canyons could be the eroded remnant of an extinct seamount. Like the scarps that traverse the Mytilus ring and the bathymetrically high area surrounding Bear Seamount, this area is also bisected by a NNW-SSE-trending, east-facing scarp (Fig. 17). The upward push of ascending magma beneath this area in the past appears to have faulted the overlying strata and moved the seafloor up to the west along this 

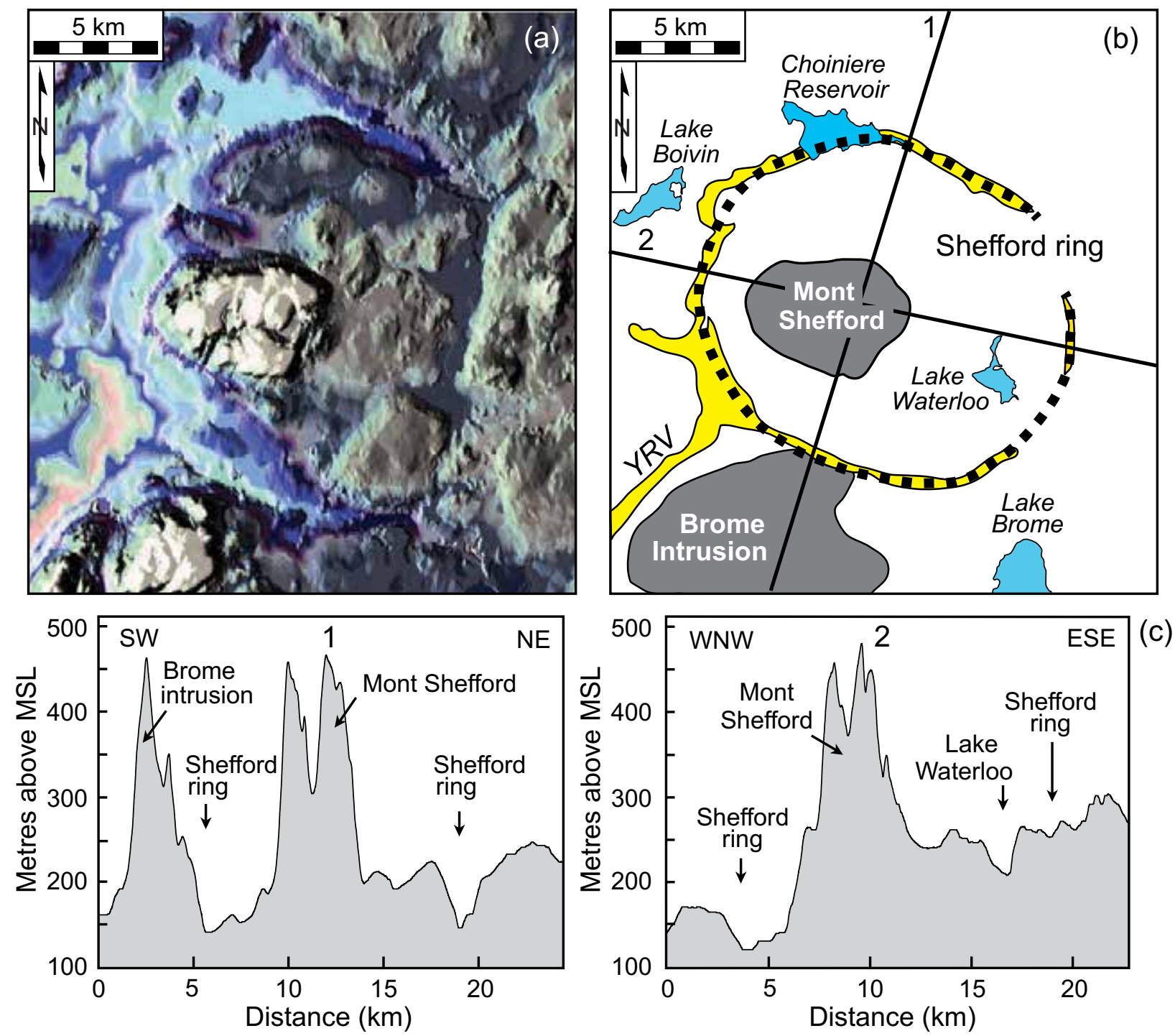

Figure 29. (a) IHS-enhanced DEM image of the Shefford ring surrounding the Shefford igneous intrusion. The colors represent elevations ranging from light tan, light blue and dark blue for the lowest elevations, to dark grey for the intermediate elevations, to medium grey and white for the highest elevations. See Figure 5 for the location of this image. (b) Interpreted drawing of (a). The thick dashed contour is the Shefford ring. The yellow patterns are fluvial valleys. YRV is the Yamaska River valley. Solid lines labeled 1 and 2 are the elevation profiles shown in (c). (c) Elevation profiles constructed across the Shefford ring.

scarp. This interpretation is supported by the $10-\mathrm{km}$-wide area of the seafloor that was uplifted by a laccolithic intrusion that penetrated the seafloor along the scarp (Fig. 18) to produce a fissure eruption and the low-lying ridge along the top of the scarp.

\section{Origin of the ring-shaped morpological features and igneous intrusions between southern Quebec and the NES}

A plausible explanation for the rings and intrusions in this area is that they were produced by the New England hotspot, as supported by several observations. First, as discussed earlier, the various rings along this trend appear to be related to igneous intrusions. Secondly, the various interpreted ring-shaped features, seamounts, volcanic necks and igneous intrusions are concentrated along the same trend (Fig. 1), which suggests that they are all related to the same mechanism. Third, their trend crosscuts the trends of interpreted basement faults along the NW-SE-oriented gravity lineaments and the Burlington lineament (Fig. 4). Furthermore, most of the MHIP is located southeast of the NW-SE-oriented Precambrian Ottawa-Bonnechere graben of the St Lawrence rift system (Fig. 1) and their trend crosscuts the NE-SW-trending terranes and faults of the St Lawrence platform and Appalachian fold belt where no NW-SE-trending faults are known to exist (Fig. 5). Lastly, the southwest-dipping, low-velocity anomaly at $\sim 200 \mathrm{~km}$ 


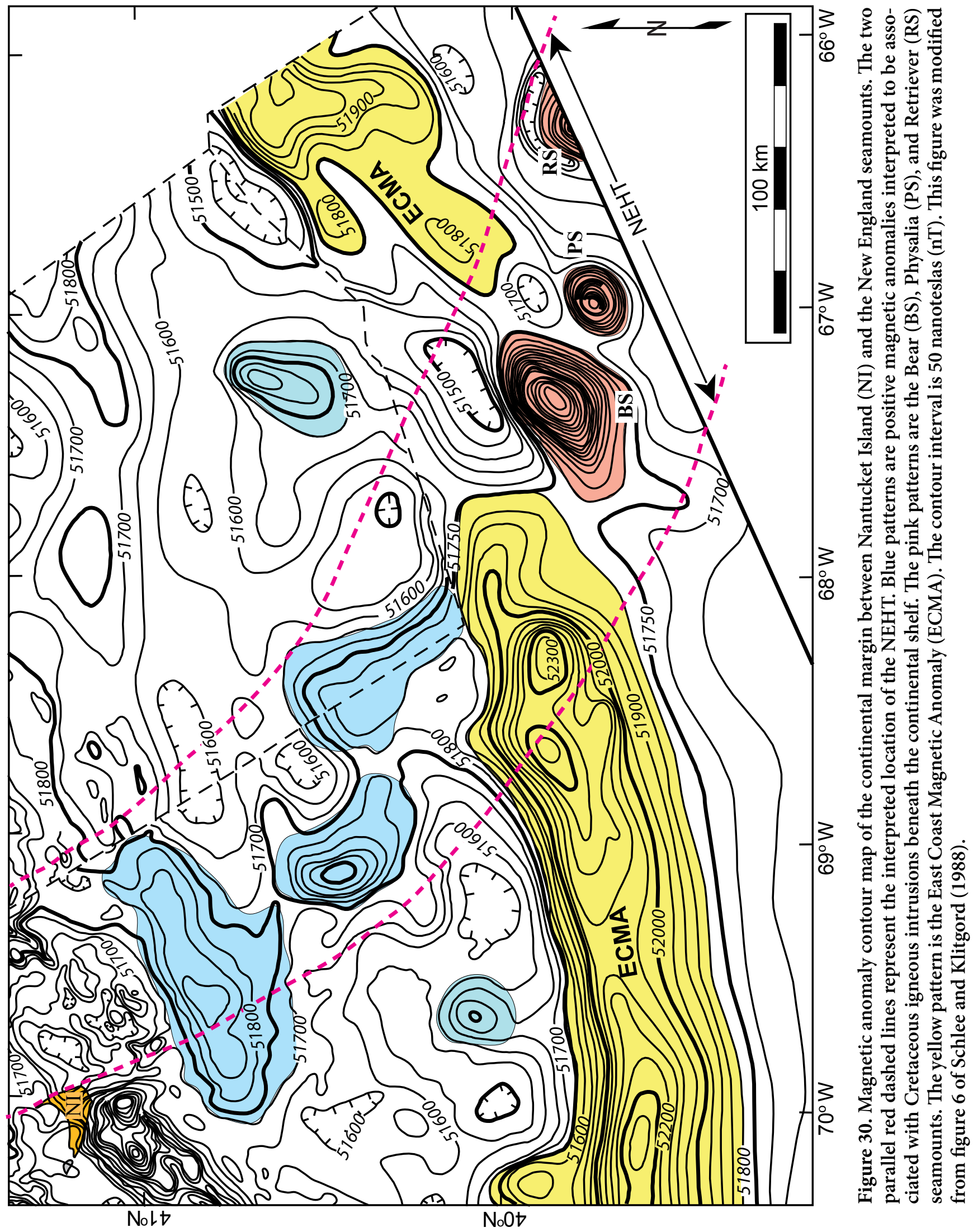

depth beneath the lower Great Lakes region (e.g., Eaton and Frederikson 2007) indicates that the NEHT continues at least $1300 \mathrm{~km}$ to the northwest from the NES.
Despite the evidence for the NEHT, the hypothesis has weaknesses. First, no consistent age progression has been documented for the mapped igneous intrusions onshore in 

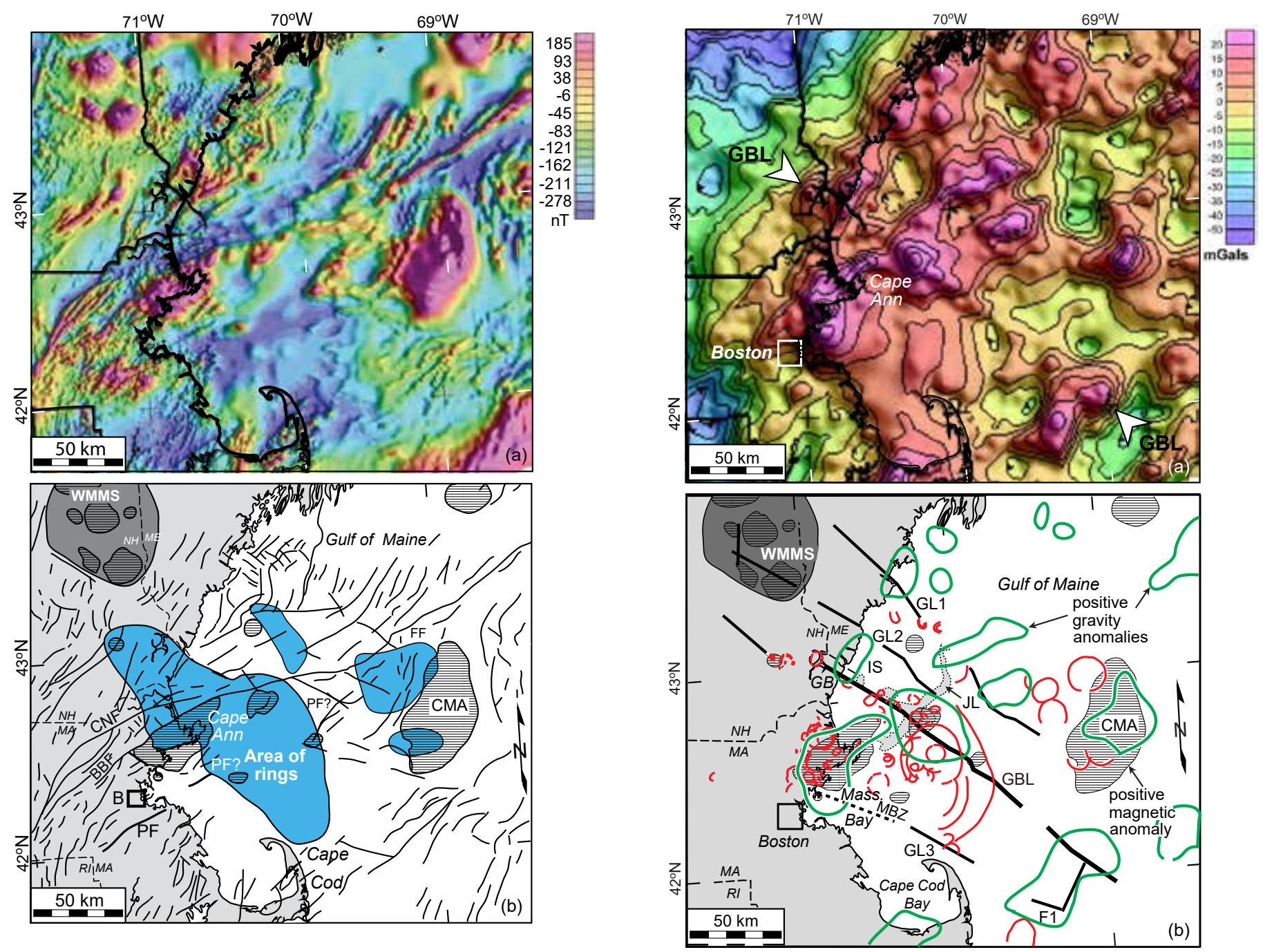

Figure 31. (a) Aeromagnetic map of eastern New England and western Gulf of Maine that was digitally illuminated from the northeast (modified from Daniels and Snyder 2004). (b) Line drawing of (a). Solid lines are linear magnetic anomalies interpreted from the magnetic image. Solid lines labeled BBF, CNF, FF, and PF are the Bloody Bluff, Clinton-Newbury, Fundy, and Ponkapoag faults. WMMS (grey pattern) is the White Mountain magma series. The blue patterns are areas of ring-shaped morphological features. The horizonal striped patterns are positive magnetic anomalies interpreted from (a). CMA is the Cashes positive magnetic anomaly. $B$ is the location of Boston.

the MHIP and WMMS. Various factors could, however, explain the lack of an age progression. For example, variations in the thickness and composition of the lithosphere affect how long it takes for magmas to ascend upward to the surface. Furthermore, sublithospheric relief causes plume material to spread laterally up-slope along inverted valleys at the base of the lithosphere while abrupt changes in the thickness of the lithosphere can cause the plume material to spread laterally along the edge of the deeper part of the lithosphere. For example, the plume head associated with the Snake River-Yellowstone hotspot in the northwestern

Figure 32. (a) Shaded relief image of contoured gravity data digitally illuminated from the northeast. Opposing arrows labeled GBL show the location of the Great Bay gravity lineament. Modified from Daniels and Snyder (2004). (b) Line drawing of (a) that shows the locations of the linear positive gravity anomalies labeled F1, GL1GL3, and GBL (Great Bay lineament) and other positive gravity anomalies outlined with green contours. IS and JL are the Isles of Shoals and Jeffreys Ledge, respectively. The horizontally striped patterns are positive magnetic anomalies interpreted from Figure 31. WMMS (grey pattern) is the White Mountain magma series. CMA is the Cashes positive magnetic anomaly. MBZ (dashed line) is the Massachusetts Bay zone of Marple and Altamura (2015b) and GB is the Great Bay estuary.

U.S. was forced beneath thinned cratonic lithosphere to the southeast prior to $12 \mathrm{Ma}$, which caused the plume tail to become tilted $65^{\circ}$ to the southeast and the hotspot track at the surface to be offset $220 \mathrm{~km}$ to the southeast from the plume at $500 \mathrm{~km}$ depth (Shervais and Hannon 2008). Thus, the lateral spread of magmas outward away from the plume head at the base of the colder lithosphere can result in outlier 


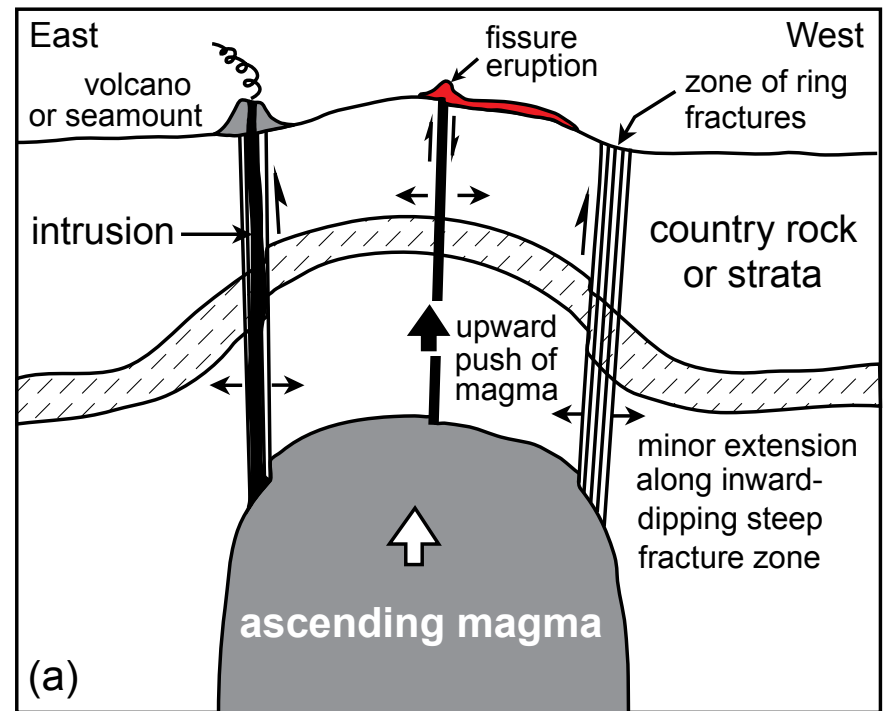

Cross-section: Cretaceous period

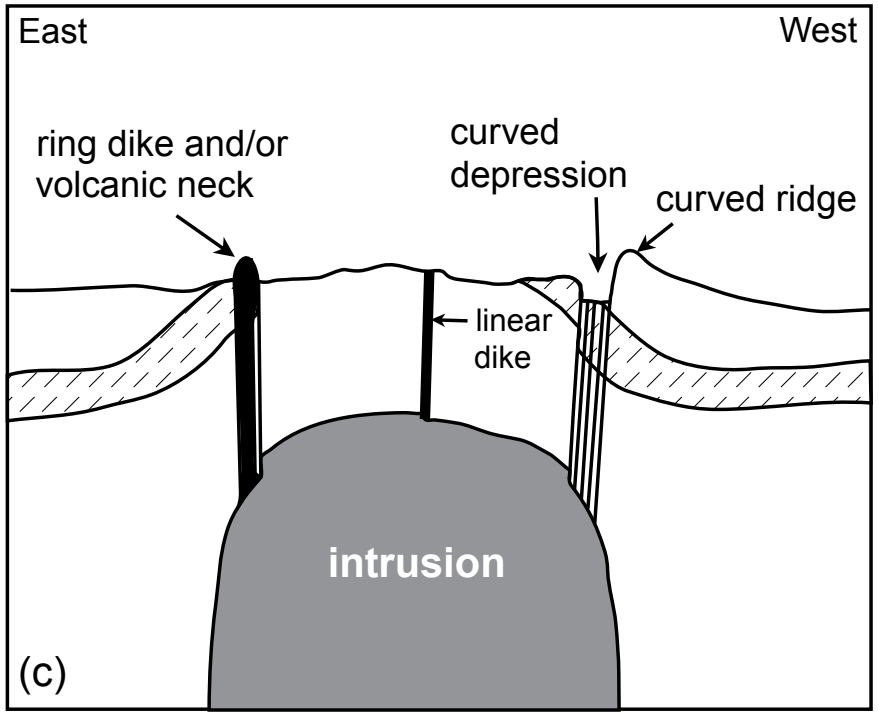

Cross-section: Today

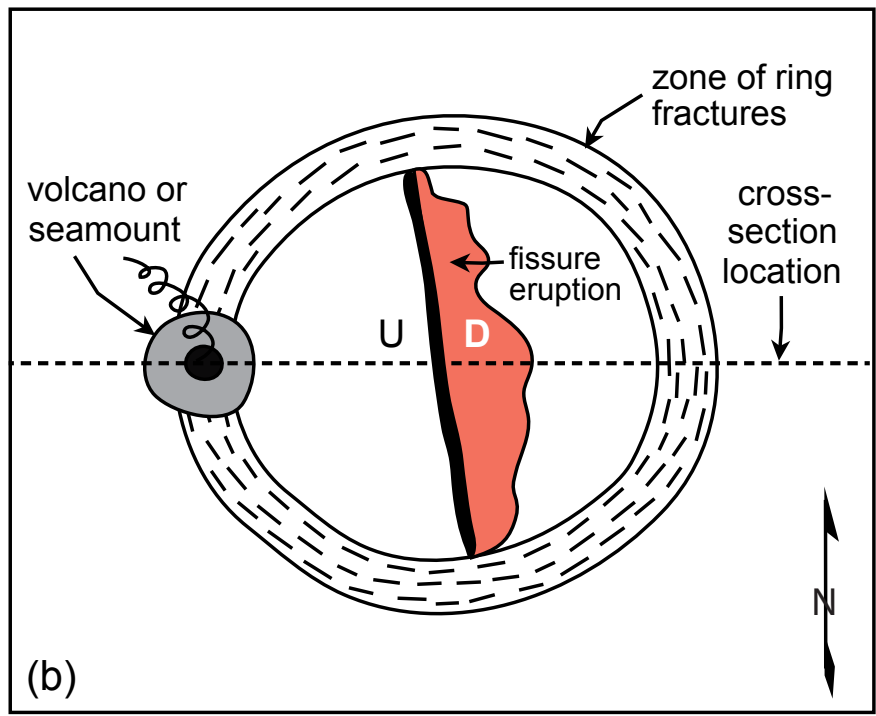

Map view: Cretaceous period

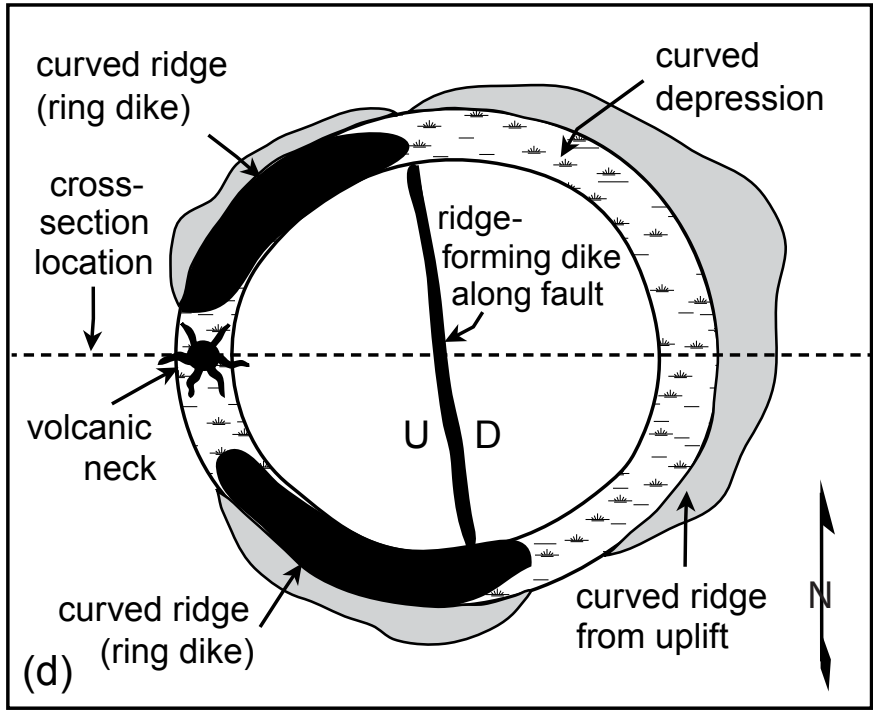

Map view: Today

Figure 33. (a) Conceptual cross-section across an ascending body of Cretaceous plume-related magma from the New England hotspot. The rising magma pushes up on the overlying rocks or strata, which domes the overlying rocks or sedimentary layers and produces ring fractures that dip steeply $\left(>70^{\circ}\right)$ inward toward the magma chamber. Minor extension across the ring fractures allows magma from below to migrate up the fractures. Magmas that reach the surface form volcanoes or fissure eruptions. The upward push of the rising magma may also cause faulting of the overlying cap rock or strata. Magmas rising along part of the fault may produce a fissure eruption along the resulting fault scarp. (b) Map view of (a). $\mathrm{U}$ is on the upthrown side of the interpreted fault. The $\mathrm{E}-\mathrm{W}$-trending dashed line is the location of the cross-section in (a). (c) Conceptual cross-section across (a) after erosion. (d) Map view of (c). The E-W-trending dashed line is the location of the cross-section in (c).

intrusions at potentially large $(>200 \mathrm{~km})$ distances from the axis of the plume track. For example, at $\sim 17 \mathrm{Ma}$, the plume head associated with the Snake River-Yellowstone hotspot beneath the relatively thin accreted terranes of the western U.S. became compressed against the relatively thick North American craton to the east, causing it to be extruded to the north against the steep cratonal boundary and to the south under thinned lithosphere (Shervais and Hannon 2008). These changes in lithosphere thickness caused plume-related volcanism as far away as northeastern Oregon (Shervais and Hannon 2008). Thus, the large variations in the composition and thickness of the continental crust beneath the northeastern United States and southern Quebec could have caused mantle material to migrate away from the plume. It is, therefore, not unusual for isolated intrusions from the NEHT to occur far from the main track, such as the Cretaceous Great Stone Dome in the Baltimore Canyon to the southwest or the Cretaceous Megantic intrusion to 
the northeast in southern Quebec (Figs. 1 and 5). Additionally, the base of the continental lithosphere beneath the northeastern USA shallows eastward toward the continental margin, which may have caused some plume material to move ahead of the hotspot. All these effects could therefore contribute to variations in the expected ages of intrusions at the surface and possibly cause a lack of age progression of intrusions along the NEHT. Furthermore, ages and compositions of the proposed intrusions offshore in the western Gulf of Maine and along the continental shelf to the southeast are unknown, and might or might not fit the hotspot track model.

Another potential weakness of the NEHT hypothesis is the misalignment between the low velocity zone in the upper mantle ( $200 \mathrm{~km}$ depth, e.g., Eaton and Frederiksen 2007) and the trend of the MHIP and WMMS (Fig. 1). This misalignment is due to the $60^{\circ}$ dip of the low velocity zone to the southwest (Aktas and Eaton 2006). The cause of the dip may be from the westward displacement of the base of the NEHT from the surface by viscous coupling of the North American cratonic keel with mantle flow (Eaton and Frederiksen 2007). Other causes for such a dip include pre-existing structural boundaries in the lithosphere. An example of such as structural boundary elsewhere that has caused a dip in the plume tail is the pre-existing crustal boundary underlain by thinner lithosphere beneath the Snake River Plain that caused the plume tail of the Snake River-Yellowstone hotspot to erode a channel into the thick cratonic lithosphere, thus causing a $65^{\circ}$ southeast dip in the plume tail that has persisted along this hotspot track to the present (Shervais and Hannon 2008).

The lack of apparent uplift along the proposed trend of the NEHT offshore also seems unusual. However, although the western Gulf of Maine is a basin-like depression today, it was a relatively high area between $\sim 190$ (Early Jurassic) and $55 \mathrm{Ma}$ ago (Eocene) (Uchupi and Bolmer 2008). Uchupi and Bolmer (2008) postulated that this apparent uplift may have been the result of igneous activity along a $65-\mathrm{km}$-wide belt between the St. Lawrence River in southern Quebec and the NES, which they referred to as the Boston-Ottawa lineation (B-OL). The timing of this uplift is consistent with the expected time during which the New England plume would have passed beneath the western Gulf of Maine during the Cretaceous period, as inferred from the Cretaceous age of the younger White Mountain intrusions and the older New England Seamounts (e.g., Duncan 1984; Eby 1987).

The younger volcanism along the NEHT also seems inconsistent with a hotspot track. For example, the small seamount on the continental slope west of Bear Seamount may be Cenozoic in age because it appears to have erupted through Cenozoic sediments on the slope (Fig. 16). Analogous to this observation is the persistent volcanic activity that has continued to occur along the Snake River-Yellowstone hotspot track to the west long after the lithosphere has passed over this area (Shervais and Hannon 2008). The cause of the younger volcanism is poorly understood, but may be due to plume tail mantle material remaining under this part of the lithosphere long after passing over this area (Ribe and Christensen 1994). Alternatively, plume tail material may have continued to flow to the southwest in the direction of plate motion if the base of the lithosphere along the former track is shallow enough to provide a sink for the buoyant, partially molten plume tail (Hannon et al. 2008).

\section{CONCLUSIONS}

Our study has revealed a broad, 900-km-long zone of mainly ring-shaped depressions between southern Quebec and the NES and small ( $<3 \mathrm{~km}$ wide) round hills in the western Gulf of Maine that we conclude are related to igneous activity. The main evidence for their igneous origin is the presence of rings surrounding some of the WMMS and MHIP intrusions and the coincidence of small seamounts and intrusions with some of the rings, both onshore and offshore. Based on the continuity of these features and the results of recent tomographic studies that indicate that the NEHT continues $1300 \mathrm{~km}$ inland from the NES, we further conclude that the numerous features along this trend are related to the NEHT.

Because of the controversial nature of the NEHT, future studies are needed to confirm its existence. Thus, it is important to carry out further investigations of the ring-shaped morphological features and interpreted small seamounts and intrusions to determine their origin, composition, and ages. Such studies could also help to better understand how mantle plumes work and how they are affected by variations in the composition and thickness of continental lithosphere, such as that beneath the northeastern USA and southern Quebec.

\section{ACKNOWLEDGEMENTS}

We thank reviewers Randy Cox and Keith Brunstad, who originally reviewed this manuscript for Northeastern Geoscience, for their many constructive comments. We also thank James Ebert, Ed Stander, and Paul Washington, the editors of Northeastern Geoscience, for permission to publish instead in Atlantic Geology, and Atlantic Geology editor Sandra Barr for her scientific feedback and help in reformatting the manuscript for that journal.

\section{REFERENCES}

Aktas, K. and Eaton, D.W. 2006. Upper-mantle velocity structure of the lower Great Lakes region. Tectonophysics, 420, pp. 267-281. https://doi.org/10.1016/j.tecto.2006.01.020

Austin, J.A., Uchupi, E., Shaughnessy, D.R., III, and Ballard, R.D. 1980. Geology of New England passive margin. American Association of Petroleum Geologists Bulletin, 64, pp. 501-526. 
Bacchus, T.S. 1993. Late Quaternary stratigraphy and evolution of the eastern Gulf of Maine. Unpublished Ph.D. thesis, University of Maine, Orono, Maine, $346 \mathrm{p}$.

Barr, S.M., Mortensen, J.K., Thompson, M.D., Hermes, O.D., and White, C.E. 2011. Early to Middle Devonian granitic and volcanic rocks from the central Gulf of Maine. Lithos, 126, pp. 455-465. https://doi.org/10.1016/j.lithos.2011.06.009

Bedard, J.H. 1985. The opening of the Atlantic, the Mesozoic New England igneous province, and mechanisms of continental breakup. Tectonophysics, 113, pp. 209-232. https://doi.org/10.1016/0040-1951(85)90197-0

Birch, F.S. 1984. Geophysical survey of bedrock on the inner continental shelf of New Hampshire. Northeastern Geology, 6, no. 2, pp. 92-101.

Crough, S.T. 1981. Mesozoic hotspot epeirogeny in eastern North America. Geology, 9, pp. 2-6. https://doi. org/10.1130/0091-7613(1981)9<2:MHEIEN >2.0.CO;2

Danforth, W.W. and Schwab, W.C. 1990. High-resolution seismic stratigraphy of the upper continental shelf seaward of Georges Bank. United States Geological Survey, Miscellaneous Field Studies Map MF-2111, 10 p., 11 sheets.

Daniels, D.L. and Snyder, S.L. 2004. New England states aeromagnetic and gravity maps and data - a web site for distribution of data. United States Geological Survey, Open-File Report 2004-1258. URL <http://pubs.usgs. gov/of/2004/1258/>, 1 November 2016.

de Boer, J.Z., McHone, J.G., Puffer, J.H., Ragland, P.C., and Whittington, D. 1988. Mesozoic and Cenozoic magmatism. In The Atlantic Continental Margin: U.S. Edited by R.E. Sheridan and J.A. Grow. Boulder, Colorado, The Geology of North America, I-2, pp. 217-241.

Dineva, S., Eaton, D., Ma, S., and Mereu, R. 2007. The October 2005 Georgian Bay (Canada) earthquake sequence: mafic dikes and their role in the mechanical heterogeneity of Precambrian crust. Bulletin of the Seismological Society of America, 97, pp. 457-473. https://doi. org/10.1785/0120060176

Duncan, R.A. 1984. Age progressive volcanism in the New England seamounts and the opening of the central Atlantic Ocean. Journal of Geophysical Research, 89, no. B12, pp. 9980-9990. https://doi.org/10.1029/JB089iB12p09980

Eaton, D.W. and Frederiksen, A. 2007. Seismic evidence for convection-driven motion of the North American plate. Nature, 446, pp. 428-431. https://doi.org/10.1038/nature 05675

Eby, G.N. 1984a. Geochronology of the Monteregian Hills alkaline igneousprovince, Quebec.Geology, 12,pp.468-470. https://doi.org/10.1130/0091-7613(1984)12<468:GOTMHA>2.0.CO;2

Eby, G.N. 1984b. Mount Pawtuckaway ring-dike complex. In Geology of the coastal lowlands, Boston, MA to Kennebunk, ME. Edited by L.S. Hanson. New England Intercollegiate Geologic Conference, Salem, MA, pp. 240-248.

Eby, G.N. 1985. Sr and $\mathrm{Pb}$ isotopes, $\mathrm{U}$ and Th chemistry of the alkaline Monteregian and White Mountain ig- neous provinces, eastern North America. Geochimica et Cosmochimica Acta, 49, pp. 1143-1153. https://doi. org/10.1016/0016-7037(85)90005-5

Eby, G.N. 1987. The Monteregian Hills and White Mountain alkaline igneous provinces, eastern North America. In Alkaline Igneous Rocks. Edited by J.G. Fitton and B.G.J. Upton, Geological Society, Special Publication 30, pp. 433-447. https://doi.org/10.1144/GSL.SP.1987.030.01.21

Eby, G.N. 1995. Part 1: White Mountain magma series. Third Hutton Symposium on Granites and Related Rocks Pre-Conference Field Trip Guide, August 22-24, 1995, Lowell, MA, 23 p.

Eby, G. N. and McHone, J. G. 1997. Plutonic and hypabyssal intrusions of the Early Cretaceous Cuttingsville complex, Vermont. In Guidebook to Field Trips in Vermont and Adjacent New Hampshire and New York. Edited by T.W. Grover, H.N. Mango, and E.J. Hasenohr, New England Intercollegiate Geological Conference, Castleton, VT, pp. B2-1-B2-16.

Eppelbaum, L.V. 2007. Localization of ring structures in Earth's environments. Journal of the Archaeological Society of the Slovakian Academy of Science, Special Issue: Archeological Prospecting, XLI, pp. 145-148.

Foland, K.A. and Faul, F. 1977. Ages of the White Mountain intrusives-New Hampshire, Vermont, and Maine, U.S.A. American Journal of Science, 277, pp. 888-904. https:// doi.org/10.2475/ajs.277.7.888

Hannon, B.B., Shervais, J.W., and Vetter, S.K. 2008. It was the deep mantle, with the Yellowstone plume, beneath the Late Archean subcontinental lithosphere: transferred lead isotope fingerprints. Geology, 36, pp. 51-54.

Heaman, L.M. and Kjarsgaard, B.A. 2000. Timing of eastern North American kimberlite magmatism: continental extension of the Great Meteor hotspot track? Earth and Planetary Science Letters, 178, pp. 253-268. https://doi. org/10.1016/S0012-821X(00)00079-0

Hibbard, J., Staal, C., Rankin, D., and Williams, H. 2006. Lithotectonic map of the Appalachian orogen (north), Canada-United States of America. Bulletin of the Geological Survey of Canada, Map 2096A. scale 1:1 500000.

Houghton, R.L., Thompson, G., and Bryan, W.B. 1977. Petrological and geochemical studies of the New England seamount chain. American Geophysical Union Transactions, $58,530 \mathrm{p}$.

Houghton, R.L., Thomas, J.E., Diecchio, R.J., and Tagliacozzo, A. 1979. Radiometric ages of basalts from DSDP leg 43, sites 382, 384, 385, 386, and 387. In Initial report of the Deep Sea Drilling Project. Edited by B.E. Tucholke and P.R. Vogt, 43, pp. 739-757.

Hutchinson, D.R., Klitgord, K.D., Lee, M.W., and Trehu, A.M. 1988. U.S. Geological Survey deep seismic-reflection profile across the Gulf of Maine. Geological Society of America Bulletin, 100, pp. 172-184. https://doi.org/10. 1130/0016-7606(1988)100<0172:USGSDS >2.3.CO;2

Klitgord, K.D., Hutchinson, D.R., and Schouten, H. 1988. U.S. Atlantic continental margin: structural and tectonic framework. In The Atlantic Continental Margin:U.S. Edited 
by R.E. Sheridan and J.A. Grow. Geological Society of America, The Geology of North America, Boulder, Colorado, I-2, pp. 19-55.

Lyons, J.B., Bothner, W.A., Moench, R.H., and Thompson, J.B., Jr. 1997. Bedrock geologic map of New Hampshire. U.S. Geological Survey, State Map Series, 2 sheets, scales 1:250 000 and 1:500 000 .

Ma, S. and Eaton, D.W. 2007. Western Quebec seismic zone (Canada): clustered, midcrustal seismicity along a Mesozoic hot spot track. Journal of Geophysical Research, 112, 16 p. B06305. https://doi.org/10.1029/2006JB004827

Manspeizer, W. and Cousminer, H.S. 1988. Late Triassic-Early Jurassic synrift basins of the U.S. Atlantic margin. In The Atlantic Continental Margin: U.S. Edited by R.E. Sheridan and J.A. Grow. Geological Society of America, The Geology of North America, Boulder, Colorado, I-2, pp. 197-216.

Marple, R.T. and Altamura, R.J. 2015a. Discovery of submerged ring structures and bathymetric lineaments in the western Gulf of Maine: further evidence for the Great Meteor hotspot track and a possible association with the 1755 Cape Ann, MA, earthquake. Geological Society of America, Abstracts with Programs, 47, p. 675.

Marple, R.T. and Altamura, R.J. 2015b. Massachusetts Bay lineament: a submerged, 100-km-long, northwest-trending brittle fault zone east of Boston, MA?. Geological Society of America, Abstracts with Programs, 47, pp. 744.

Marple, R.T., Altamura, R.J., and Hurd, J., Jr. 2015. Ringshaped structures in the southwestern Gulf of Maine. Northeastern Geoscience, 33, pp. 22-24.

MassGIS Data. 2016. MassGIS data - LiDAR terrain data: URL <http://www.mass.gov/anf/research-and-tech/itserv-and-support/application-serv/office-of-geographic-information-massgis/datalayers/lidar.html>, 1 December 2016.

McHone, J.G. 1996. Constraints on the mantle plume model for Mesozoic alkaline intrusions in northeastern North America. The Canadian Mineralogist, 34, pp. 325-334.

McHone, J.G. and Shake, S.N. 1992. Structural control of Mesozoic magmatism in New England. In Basement Tectonics 7. Edited by R. Mason. Proceedings of the International Conferences on Basement Tectonics, 1, Springer, Dordrecht, pp. 399-407. https://doi.org/10.1007/978-94017-0833-3 29

Mitchell, N.C. 2005. Interpreting long-profiles of canyons in the USA Atlantic continental slope. Marine Geology, 214, pp. 75-99. https://doi.org/10.1016/j.margeo.2004.09.005

Natural Resources Canada. 2017. Geospatial data extraction. URL < http://maps.canada.ca/czs/index-en.html $>1$ January 2017.

NH GRANIT. 2016. The New Hampshire Geographically Referenced Analysis and Information Transfer System, Earth Systems Research Center, Institute for the Study of Earth, Oceans, and Space, University of New Hampshire. URL $<$ http://www.granit.edu/>, 1 December 2016.

Oldale, R.N. 1994. The geology of Stellwagen Bank. United States Geological Survey, Open-File Report 94-672, 17 p.
Poag, C.W. 1982. Stratigraphic reference section for Georges Bank Basin-depositional model for New England passive margin. American Association of Petroleum Geologists Bulletin, 66, pp. 1021-1041.

Pratson, L.F. and Coakley, B.J. 1996. A model for the headward erosion of submarine canyons induced by downslope-eroding sediment flows. Geological Society of America Bulletin, 108, pp. 225-234. https://doi.org/10.11 30/0016-7606(1996)108<0225:AMFTHE $>2.3$. CO;2

Ratcliffe, N.M., Stanley, R.S., Gale, M.H., Thompson, P.J., and Walsh, G.J. 2011. Bedrock geologic map of Vermont. United States Geological Survey, Scientific Investigations Map 3184, 3 sheets, scale 1:100 000.

Ribe, N.M. and Christensen, U.R. 1994. Three-dimensional modeling of plume-lithosphere interaction. Journal of Geohysical Research, 99(B1), pp. 669-682. https://doi. org/10.1029/93JB02386

Roden-Tice, M.K., West, D.P., Jr., Potter, J.K., Raymond, S.M., and Winch, J.L. 2009. Presence of a long-term lithospheric thermal anomaly: evidence from apatite fission-track analysis in northern New England. The Journal of Geology, 117, pp. 627-641. https://doi.org/10.1086/605995

Rondenay, S., Bostock, M.G., Hearn, T.M., White, D.J., and Ellis, R.M. 2000. Lithospheric assembly and modification of the SE Canadian Shield: Abitibi-Grenville teleseismic experiment. Journal of Geophysical Research: Solid Earth, 105, issue B6, pp. 13735-13754. https://doi. org/10.1029/2000JB900022

Roulleau, E. and Stevenson, R. 2013. Geochemical and isotopic (Nd-Sr-Hf- $\mathrm{Pb}$ ) evidence for a lithospheric mantle source in the formation of the alkaline Monteregian province (Quebec). Canadian Journal of Earth Sciences, 50, pp. 650-666. https://doi.org/10.1139/cjes-2012-0145

Schlee, J.S. and Klitgord, K.D. 1988. Georges Bank Basin: a regional synthesis. In The Atlantic Continental Margin: U.S. Edited by R.E. Sheridan and J.A. Grow, Geological Society of America, The Geology of North America, Boulder, Colorado, I-2, pp. 243-268. https://doi.org/10.1130/ DNAG-GNA-I2.243

Schlee, J.S., Poag, C.W., and Hinz, K. 1985. Seismic stratigraphy of the continental slope and rise seaward of Georges Bank. In Geologic Evolution of the United States Atlantic Margin. Edited by C.W. Poag. New York, Van Nostrand Reinhold, pp. 265-292.

Schmandt, B. and Lin, F.-C. 2014. P and S wave tomography of the mantle beneath the United States. Geophysical Research Letters, 41, pp. 6342-6349. https://doi. org/10.1002/2014GL061231

Schnitker, D., Bellnap, D.F., Bacchus, T.S., Firiez, J.K., Lusardi, B.A., and Popek, D.M. 2001. Deglaciation of the Gulf of Maine. In Deglacial History and Relative Sea-level Changes, Northern New England and Adjacent Canada. Edited by T.K. Weddle and R.M. Retelle. Geological Society of America, Special Paper 351, pp. 9-34. https://doi. org/10.1130/0-8137-2351-5.9

Shervais, J.W. and Hanan, B.B. 2008. Lithospheric topography, tilted plumes, and the track of the Snake River- 
Yellowstone hot spot. Tectonics, 27, TC5004, 17 p. https:// doi.org/10.1029/2007TC002181

Sleep, N.H. 1990. Monteregian hotspot track: a long-lived mantle plume. Journal of Geophysical Research, 95, pp. 21983-21990. https://doi.org/10.1029/JB095iB13p21983

Stone, B.D., Stone, J.R., and DiGiacomo-Cohen, M.L. 2006. Surficial geologic map of the Salem Depot-Newburyport East-Wilmington-Rockport 16-quadrangle area in northeast Massachusetts. United States Geological Survey, Open-File Report 2006-1260B, 18 p., 1 sheet, scale 1:50 000 .

Taras, B.D. and Hart, S.R. 1987. Geochemical evolution of the New England seamount chain: isotopic and traceelement constraints. Chemical Geology, 64, pp. 35-54. https://doi.org/10.1016/0009-2541(87)90150-1

Thompson, M.D., Ramezani, J., and Crowley, J.L. 2014. $\mathrm{U}-\mathrm{Pb}$ zircon geochronology of Roxbury Conglomerate, Boston Basin, Massachusetts: tectono-stratigraphic implications for Avalonia in and beyond SE New England. American Journal of Science, 314, pp. 1009-1040. https:// doi.org/10.2475/06.2014.02

Tremblay, A. and Pinet, N. 2016. Late Neoproterozoic to Permian tectonic evolution of the Quebec Appalachians, Canada. Earth Science Reviews, 160, pp. 131-170. https:// doi.org/10.1016/j.earscirev.2016.06.015

Triezenberg, P.J., Hart, P.E., and Childs, J.R. 2016. National Archive of Marine Seismic Surveys (NAMSS): a USGS data website of marine seismic-reflection data within the U.S. Exclusive Economic Zone (EEZ). United States Geological Survey Data Release. https//doi.org/10.5066/ F7930R7P

Tucholke, B.E. and Mountain, G.S. 1979. Seismic stratigraphy, lithostratigraphy and paleosedimentation patterns in the North American Basin. In Deep Drilling Results in the Atlantic Ocean: Continental Margins and Paleoenvironment. Edited by M. Talwani, W. Hay, and W.B.F. Ryan. American Geophysical Union, Maurice Ewing Series, Proceedings of Symposium, no. 3, pp. 58-86. https://doi. org/10.1029/ME003p0058

Uchupi, E. 1968. The Atlantic continental shelf and slope of the United States-physiography. United States Geological Survey, Professional Paper 529-C, 30 p.

Uchupi, E. and Austin, J.A. 1979. The geologic history of the passive margin off New England and the Canadian maritime provinces. In Crustal Properties Across Passive Margins. Edited by C.E. Keen. Tectonophysics, 59, no. 1-4, pp. 53-69. https://doi.org/10.1016/B978-0-44441851-7.50007-8

Uchupi, E. and Bolmer, S.T. 2008. Geologic evolution of the Gulf of Maine region. Earth Science Reviews, 91, issue 1, pp. 27-76. https://doi.org/10.1016/j.earscirev.2008.09.002 Uchupi, E., Ballard, R.D., and Ellis, J.P. 1977. Continental slope and rise off western Nova Scotia and Georges Bank. American Association Petroleum Geologists Bulletin, 61, pp. 1483-1492.

UNH/CCOM-JHC. 2015a. Western Gulf of Maine bathymetric synthesis. URL <http://ccom.unh.edu/gis/FlexViewer3.7/GoM/index.html? config=config-bathymetry. xml>, 1 December 2015.

UNH/CCOM-JHC. 2015b. Atlantic margin bathymetry. URL <http://ccom.unh.edu/gis/flexviewers/AtlanticBathymetry/index.html>, 1 December 2015.

United States Geological Survey. 2017. The National Map: 3D Elevation Program (3DEP). URL $<$ https://nationalmap.gov/3DEP/index.html>, 1 January 2017.

Valentine, P.C. 1981. Continental margin stratigraphy along U.S. Geological Survey seismic line 5: Long Island platform and western Georges Bank Basin. United States Geological Survey, Miscellaneous Field Studies Map MF857, 2 sheets.

Villemaire, M., Darbyshire, F.A., and Bastow, I.D. 2012. P-way tomography of eastern North America: evidence for mantle evolution from Archean to Phanerozoic, and modification during subsequent hot spot tectonism. Journal of Geophysical Research, 117, 15 p., B12302. https:// doi.org/10.1029/2012JB009639

Ward, L. and Johnson, P. 2016. Jeffreys Ledge: high resolution mapping and characterization of the seafloor. URL $<$ http://ccom.unh.edu/project/jeffreys-ledge>, 1 December 2016.

White, C.E. and Barr, S.M. 2012. Meguma terrane revisited: stratigraphy, metamorphism, paleontology, and provenance. GAC-MAC 2012 Field Guide Summary, Journal of the Geological Association of Canada, 39, Geoscience Canada. URL <https://journals.lib.unb.ca/index.php/ GC/article/view/19450/21004>, 1 November 2017.

Zen, E., Goldsmith, R., Ratcliffe, N.M., Robinson, P.R., Hatch, N.L., Jr., Shride, A.F., Weed, E.G.A., and Wones, D.R. 1983. Bedrock geologic map of Massachusetts. United States Geological Survey, Open File Report, 3 sheets, 1:250 000 .

Zurevinski, S.E., Heaman, L.M., and Creaser, R.A. 2011. The origin of Triassic/Jurassic kimberlite magmatism, Canada: two mantle sources revealed from the Sr-Nd isotopic composition of groundmass perovskite. Geochemistry Geophysics Geosystems, 12, no. 9, 19 p., Q09005. https:// doi.org/10.1029/2011GC003659

Editorial responsibility: Sandra M. Barr 